\title{
EVALUASI KENYAMANAN TERMAL DAN KECUKUPAN RUANG TERBUKA HIJAU DI KAWASAN INDUSTRI PT KRAKATAU STEEL, KOTA CILEGON
}

\section{LUPITA RACHMA}

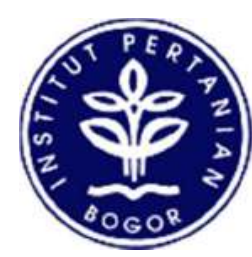

\author{
DEPARTEMEN ARSITEKTUR LANSKAP \\ FAKULTAS PERTANIAN \\ INSTITUT PERTANIAN BOGOR \\ BOGOR \\ 2018
}




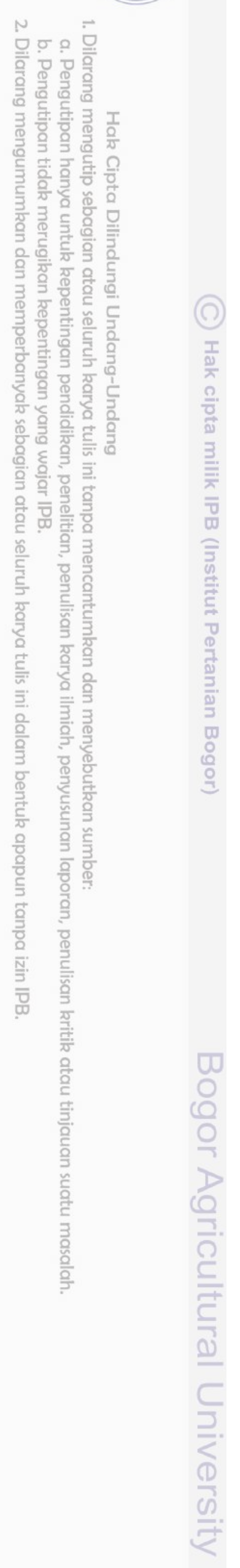




\section{PERNYATAAN MENGENAI SKRIPSI DAN SUMBER INFORMASI SERTA PELIMPAHAN HAK CIPTA*}

Dengan ini saya menyatakan bahwa skripsi berjudul Evaluasi Kenyamanan
Termal dan Kecukupan Ruang Terbuka Hijau di Kawasan Industri PT Krakatau
Steel, Kota Cilegon adalah benar karya saya dengan arahan dari komisi
pembimbing dan belum diajukan dalam bentuk apa pun kepada perguruan tinggi
mana pun. Sumber informasi yang berasal atau dikutip dari karya yang diterbitkan
maupun tidak diterbitkan dari penulis lain telah disebutkan dalam teks dan
dicantumkan dalam Daftar Pustaka di bagian akhir skripsi ini.
Dengan ini saya melimpahkan hak cipta dari karya tulis saya kepada Institut
Pertanian Bogor.
Bogor, September 2018
Lupita Rachma
NIM A44140033 


\begin{abstract}
ABSTRAK
LUPITA RACHMA. Evaluasi Kenyamanan Termal dan Kecukupan Ruang Terbuka Hijau di Kawasan Industri PT Krakatau Steel, Kota Cilegon. Dibimbing oleh TATI BUDIARTI.

Penelitian ini berfokus pada RTH di kawasan industri PT Krakatau Steel yang merupakan kawasan industri besar yang berlokasi di Kota Cilegon. Penelitian ini bertujuan untuk mengalisis kesesuaian kenyamanan termal dan kecukupan RTH, serta menyusun rekomendasi perbaikan RTH. Metode penelitian menggunakan metode deskriptif melalui perbadingan RTH dengan peraturan yang berlaku, perhitungan Thermal Humidity Index (THI), kuesioner terhadap persepsi dan preferensi karyawan dan masyarakat, serta perhitungan SWOT (strength, weaknesses, opportunity, and Threats). Berdasarkan hasil pengamatan RTH memiliki luas $12 \%$ dari luas kawasan industri dan telah memenuhi kewajiban luas RTH minimal 10\% menurut peraturan. Berdasarkan hasil perhitungan THI, kenyamanan termal pada lokasi penelitian termasuk dalam kategori tidak nyaman yang menunjukkan bahwa RTH yang ada tidak berpengaruh besar pada kenyamanan termal. Berdasarkan hasil evaluasi SWOT, ruang terbuka hijau ini berada pada posisi hold and maintain sehingga dapat diterapkan strategi berupa optimalisasi pengelolaan dan pemanfaatan ruang terbuka hijau yang telah ada. Berdasarkan kuesioner terhadap karyawan, RTH sudah dapat memberikan kenyamanan namun RTH masih belum cukup, terutama perlunya tambahan taman-taman baru dan fasilitas pada RTH perlu ditambahkan. Berdasarkan kuesioner terhadap masyarakat, RTH sudah cukup baik tetapi masyarakat menginginkan penambahan RTH di luar kawasan industri yang dapat menyaring debu agar tidak mencapai permukiman.
\end{abstract}

Kata kunci: evaluasi, kecukupan, kenyamanan termal, ruang terbuka hijau

\begin{abstract}
LUPITA RACHMA. The Evaluation of Thermal Comfort and Sufficiency of Green Open Space in Industrial Area PT Krakatau Steel, Cilegon City. Supervised by TATI BUDIARTI.

This research was focused on green open space in industrial area of PT Krakatau Steel which is a big industrial area located in Cilegon city. This study aims to analyze green open space's thermal comfort and sufficiency, as well as to make recommendations for green open space improvement. The research method used descriptive method through comparison between green open space area with prevailing regulations, calculation of Thermal Humidity Index (THI), questionnaires to the perception and preference of employee and community, and SWOT calculation (strength, weaknesses, opportunity and threats). Based on observations, green open space area is $12 \%$ of total industrial area and has reached the minimum green open space at $10 \%$ according to the regulation. Based on the THI calculation, thermal comfort at the research study classified in the category of uncomfortable, indicating the existing green open space has no significant effect on termal comfort. Based on SWOT evaluation, this green open space is on hold and maintained position. Based on questionnaires on employees, green open space is able to provide comfort but its not like what employees expected, especially the need for additional new parks and the addition of facilities on green open space. Based on questionnaires on
\end{abstract}


community, green open space is good enough, but they wants additional green open space outside the industrial estate that can filtering dust so the dust cant reach settlement area.

Keywords: evaluation, industrial estate, sufficiency, thermal comfort 


\title{
EVALUASI KENYAMANAN TERMAL DAN KECUKUPAN RUANG TERBUKA HIJAU DI KAWASAN INDUSTRI PT KRAKATAU STEEL, KOTA CILEGON
}

\section{LUPITA RACHMA}

\author{
Skripsi \\ sebagai salah satu syarat untuk memperoleh gelar \\ Sarjana Pertanian \\ pada \\ Departemen Arsitektur Lanksap
}

\author{
DEPARTEMEN ARSITEKTUR LANSKAP \\ FAKULTAS PERTANIAN \\ INSTITUT PERTANIAN BOGOR \\ BOGOR \\ 2018
}




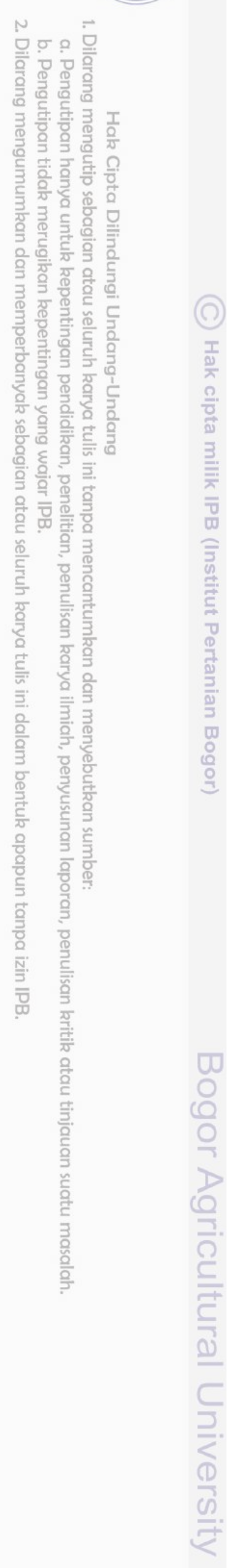


Judul Skripsi: Evaluasi Kenyamanan Termal dan Kecukupan Ruang Terbuka Hijau di Kawasan Industri I'T Krakatau Steel, Kota Cilegon

Nama : Lupita Rachma

NIM : A44140033

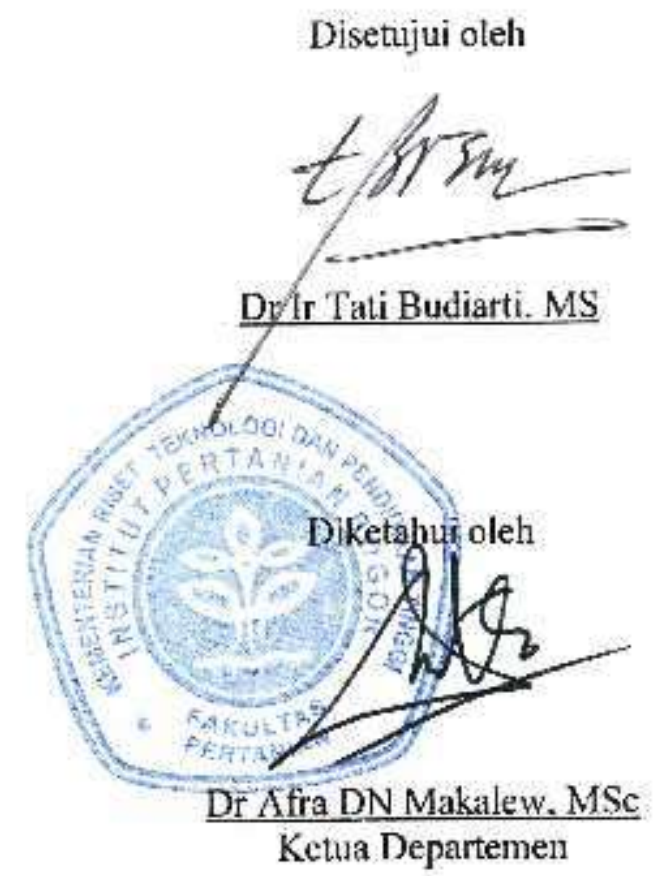

Tanggal Lulus: 10 SEP 2018 


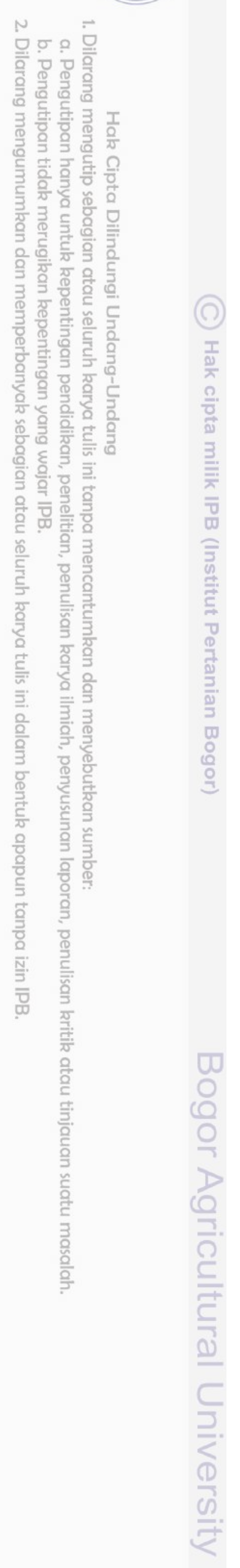




\section{PRAKATA}

Puji dan syukur penulis panjatkan kehadirat Allah SWT. yang telah melimpahkan rahmat dan hidayah-Nya sehingga penelitian yang berjudul "Evaluasi Kesesuaian Kenyamanan Termal dan Kecukupan Ruang Terbuka Hijau di Kawasan Industri PT Krakatau Steel, Kota Cilegon" ini dapat diselesaikan. Penelitian ini disusun dalam rangka memenuhi syarat berupa tugas akhir untuk mendapatkan gelar sarjana arsitektur lanskap.

Keberhasilan penyelesaian skripsi ini tidak terlepas dari dukungan berbagai pihak dan penulis ingin mengucapkan terimakasih sebesar-besarnya kepada:

1. Orang tua tercinta, Bapak Marlan dan Ibu Tuti Astuti yang tidak ada hentihentinya memberikan dukungan berupa doa, motivasi, perhatian, serta materil.

2. Dr. Ir. Tati Budiarti, M.S, selaku pembimbing yang memberi bantuan, dukungan, serta arahan kepada penulis selama penyelesaian karya ilmiah ini.

3. Dr. Ir. Bambang Sulistyantara, MAgr dan Dr. Ir. Indung Sitti Fatimah, MSi sebagai penguji skripsi yang telah memberikan saran untuk perbaikan penulisan skripsi.

4. Seluruh karyawan Divisi General Affair dan Divisi K3LH PT Krakatau Steel yang telah memberikan izin, membantu inventarisasi tapak, pengambilan data, serta memberikan informasi yang diperlukan dalam penyelesaian penelitian.

5. Karyawan PT Krakatau Steel yang telah bersedia menjadi responden penelitian.

6. Pandu, yang senantiasa membantu, mendengarkan keluh kesah selama pembuatan skripsi, menghibur, dan memberikan motivasi untuk terus maju.

7. Rekan-rekan Arsitektur Lanskap IPB angkatan 51 yang sudah selama 8 semester bersama-sama, merasakan susah dan senang menjadi mahasiswa departemen arsitektur lanskap.

8. Sarah, teman satu kost yang selalu bersama penulis melewati berbagai kesulitan, dan senantiasa memberi semangat serta membantu penulis.

9. Gengs BabyPici, Nadia, Rizza, Ajeng, Lala, Nisa, Puji yang merasakan suka duka bersama penulis, serta menjadi tempat bertukar informasi dan senantiasa memberikan motivasi.

10.Umat Kost Lestari, April dan Tari, yang senantiasa memberikan motivasi dan membantu penulis dalam pengerjaan skripsi.

11.Teman dekat semasa kuliah, Opi, Cia, Evi, Tari, Zaki, Yunna, Nada, Audry, Rai, Nopi, Nadya, Yaya dan Micol atas dukungannya dalam pengerjaan skripsi.

12.Teman-teman SMA, Cia, Ani, Fierda, Ummu, Ana, Via, Lita, dan Uyan, yang selalu mendengarkan keluh kesah selama pembuatan skripsi,.

13.Bunda peri squad, Dewi, Anggi, Intan, Desy, dan Yuyung yang sering membantu, menjadi tempat bertukar informasi, dan memberikan motivasi.

14.Seluruh pihak yang tidak dapat disebutkan satu-persatu yang telah berjasa dalam membantu penulis menyelesaikan skripsi ini.

Akhir kata, penulis berharap agar skripsi ini dapat bermanfaat bagi berbagai pihak sebagai referensi dalam mengelola RTH di kawasan industri.

Bogor, September 2018

Lupita Rachma 


\section{DAFTAR ISI}

DAFTAR TABEL $\quad$ xii

DAFTAR GAMBAR $\quad$ xiii

DAFTAR LAMPIRAN xiv

PENDAHULUAN 1

Latar Belakang 1

Tujuan Penelitian 2

Manfaat Penelitian 2

Kerangka Pikir 2

TINJAUAN PUSTAKA

Kawasan Industri 3

Dampak Kegiatan Industri 4

Ruang Terbuka Hijau 6

RTH pada Kawasan Industri $\quad 7$

Hubungan RTH dengan Kenyamanan Termal 9

Evaluasi 10

METODOLOGI 10

Lokasi Penelitian $\quad 10$

Waktu Penelitian 11

$\begin{array}{ll}\text { Alat dan Bahan } & 12\end{array}$

Batasan Penelitian $\quad 13$

$\begin{array}{lr}\text { Metode Penelitian } & 13\end{array}$

Tahap Persiapan 13

Tahap Pelaksanaan $\quad 13$

KONDISI UMUM 21

Kondisi Fisik Kota Cilegon $\quad 21$

Sejarah PT Krakatau Steel 23

Kondisi Fisik Lokasi Penelitian $\quad 24$

Lokasi 24

Iklim $\quad 24$

Tanah 26

Topografi $\quad 27$

Hidrologi $\quad 27$

$\begin{array}{ll}\text { Tata Guna Lahan } & 28\end{array}$

$\begin{array}{ll}\text { Pembagian Kawasan Industri } & 28\end{array}$

Kualitas Udara 31

Limbah $\quad 31$

HASIL DAN PEMBAHASAN $\quad 32$

Analisis Kecukupan Ruang Terbuka Hijau $\quad 32$

Jenis RTH di Kawasan Industri $\quad 34$

Analisis Kenyamanan Termal $\quad 45$

Analisis RTH terhadap Suhu Udara $\quad 48$

Analisis RTH Terhadap Kenyamanan Manusia $\quad 53$

Analisis Persepsi dan Preferensi Karyawan $\quad 56$

Karakteristik karyawan $\quad 56$

$\begin{array}{ll}\text { Persepsi karyawan terhadap Kawasan Industri } & 57\end{array}$ 
Persepsi karyawan terhadap ruang terbuka hijau (RTH) 57

Aktivitas Karyawan di Ruang Terbuka Hijau $\quad 60$

Analisis Persepsi dan Preferensi Masyarakat $\quad 63$

Analisis SWOT $\quad 67$

Identifikasi kekuatan, kelemahan, peluang, dan ancaman 67

Penilaian Faktor Internal dan Eksternal $\quad 70$

$\begin{array}{ll}\text { Matriks SWOT } & 74\end{array}$

Pembuatan Tabel Rangking Alternatif Strategi $\quad 75$

$\begin{array}{ll}\text { Evaluasi } & 77\end{array}$

$\begin{array}{ll}\text { Aspek Kecukupan RTH } & 77\end{array}$

$\begin{array}{ll}\text { Aspek Kenyamanan Termal } & 78\end{array}$

$\begin{array}{ll}\text { Rekomendasi } & 79\end{array}$

Aspek Kecukupan RTH $\quad 79$

Aspek Kenyamanan Termal $\quad 82$

Strategi Pengembangan RTH $\quad 83$

$\begin{array}{lr}\text { SIMPULAN DAN SARAN } & 83\end{array}$

Simpulan $\quad 83$

$\begin{array}{lr}\text { Saran } & 84\end{array}$

DAFTAR PUSTAKA $\quad 84$

RIWAYAT HIDUP 96

\section{DAFTAR TABEL}

1 Daya Serap Ruang Terbuka Hijau terhadap Polusi Udara 8

2 Jenis Kegiatan dan Waktu Pelaksanaan 12

3 Alat dan Kegunaannya 12

4 Jenis dan Sumber Data 12

5 Jenis Vegetasi dalam Pengukuran Suhu dan Kelembaban 15

6 Formulasi Pembobotan Faktor Internal 19

7 Formulasi Pembobotan Faktor Eksternal 19

8 Formulasi Penilaian Faktor Internal 19

9 Formulasi Penilaian Faktor Eksternal 20

10 Matriks SWOT 21

11 Jenis dan Sifat Tanah di PT Krakatau Steel 26

12 Konsentrasi Polusi Udara di Lingkungan Industri PT KS 31

13 Jenis dan Jumlah Tanaman di Taman CRM 35

14 Jenis dan Jumlah Tanaman di Taman Masjid HSM 37

15 Jenis Tanaman di Daerah Penyangga Kawasan Industri 39

16 Pengukuran Suhu, Kelembaban, dan Nilai THI pada Taman CRM 45

17 Pengukuran Suhu, Kelembaban, dan Nilai THI pada Taman Masjid HSM 46

18 Pengukuran Suhu, Kelembaban, dan Nilai THI pada Jalur Hijau Jalan 46

19 Pengukuran Suhu, Kelembaban, dan Nilai THI pada RTH Pabrik DRP 47

20 Pengukuran Suhu, Kelembaban, dan Nilai THI pada RTH Kantor HSE 47

21 Pengukuran Suhu, Kelembaban, dan Nilai THI pada Lapangan 48

22 Penilaian Tingkat Kepentingan Faktor Internal 70

23 Penilaian Tingkat Kepentingan Faktor Eksternal 71

24 Penentuan Nilai Bobot Faktor Internal 71 
26 Penilaian Faktor Internal di Kawasan Industri PT. KS 72

27 Penilaian Faktor Eksternal di Kawasan Industri PT. KS 73

28 Matriks SWOT RTH Kawasan Industri PT KS 75

29 Perangkingan Alternatif Strategi Perbaikan RTH 76

30 Hasil Perhitungan Nilai THI 78

\section{DAFTAR GAMBAR}

1 Kerangka Pikir Penelitian 3

2 Kota Cilegon 11

3 Kawasan Industri PT Krakatau Steel 11

4 Lokasi Pengukuran Suhu dan Kelembaban 15

5 Lokasi Permukiman Masyarakat 17

6 Matriks Internal-Eksternal 20

7 Peta Kota Cilegon 22

$8 \quad$ Lokasi PT Krakatau Steel 24

9 Grafik Beberapa Unsur Iklim Bulanan 25

10 Peta Tanah di Kawasan Industri Krakatau 27

11 Basemap Kawasan Industri PT Krakatau Steel 30

12 Peta Persebaran RTH di Kawasan Industri 33

13 Taman CRM $1 \quad 34$

14 Taman CRM 2

15 Taman Kebugaran 34

16 Shelter untuk Parkir Mobil 34

17 Gazebo Tempat Karyawan beristirahat 34

18 Kondisi Awal Lapangan 36

19 Kondisi Lapangan Dua Minggu Kemudian 36

20 Badan Air di Taman HSM 37

21 Jembatan di Taman HSM 37

22 Kondisi Bagian Samping $\quad 37$

23 Kondisi Pedestrian Track 37

24 Tampak Depan Masjid $\quad 37$

25 Masjid HSM $\quad 37$

26 Jalur Hijau Jalan di HSE 38

27 Jalur hijau Jalan di CRM 38

28 Jalur Hijau Jalan di HSM 38

29 Jalur Hijau Jalan di WRM 38

30 RTH Pabrik HSM 40

31 RTH Pabrik WRM 40

32 RTH Pabrik DRP 40

33 RTH Pabrik BSP 40

34 RTH Kantor HSE $\quad 40$

35 Inventarisasi Taman CRM 41

36 Taman Inventarisasi Masjid HSM 42

37 Persebaran Tanaman pada Jalur Hijau 43

38 Persebaran Tanaman pada Buffer Zone 44 
39 Grafik Perubahan Suhu Udara 49

40 Grafik Perubahan Kelembaban Udara 51

41 Hasil Perhitungan Temperatur Humidity Index (THI) 53

42 Hasil Pengukuran THI 54

43 Lama Bekerja Karyawan yang Menjadi Responden 57

44 Persepsi Karyawan terhadap Kondisi Kawasan Industri 57

45 Pengetahuan Karyawan Mengenai RTH 58

46 Persepsi Karyawan terhadap Penyebab Ketidaknyamanan 58

47 Persepsi Karyawan terhadap Kenyamanan pada RTH 59

48 Persepsi Karyawan terhadap Hubungan RTH dan Lingkungan 60

49 Persepsi Karyawan terhadap Kondisi RTH 60

50 Intensitas Aktivitas Karyawan pada RTH 60

51 Aktivitas Karyawan pada Jam Istirahat 61

52 Persepsi Terhadap Fasilitas pada RTH 62

53 Persepsi terhadap Jumlah Pohon Peneduh 62

54 Persepsi Pengaruh Penataan Pohon dalam Mengurangi Kejenuhan 62

55 Preferensi Fasilitas yang Perlu ditambahkan 62

56 Persepsi Karyawan terhadap Kriteria Lokasi Beristirahat 63

57 Karakteristik Masyarakat Berdasarkan Lamanya Tinggal 63

58 Persepsi Masyarakat terhadap Peran Industri pada Lingkungan 64

59 Karakteristik Masyarakat berdasarkan Aktivitas 64

60 Keuntungan dan Kerugian menurut Masyarakat 65

61 Persepsi Masyarakat terhadap Kawasan Industri 65

62 Persepsi Masyarakat terhadap Kenyamanan 65

63 Persepsi Masyarakat terhadap Faktor Pendorong Kenyamanan 66

64 Persepsi terhadap RTH Kawasan Industri PT KS 66

65 Persepsi Masyarakat terhadap Kondisi Lingkungan 67

66 Matriks Internal Eksternal $\quad 73$

67 Ilustrasi Taman pada Kawasan Pabrik $\quad 80$

68 Ilustrasi Green Belt $\quad 81$

69 Ilustrasi Penghijauan di Dekat Bangunan Pabrik 82

\section{DAFTAR LAMPIRAN}

1 Lembar Kuesioner Karyawan $\quad 88$

2 Lembar Kuesioner Masyarakat $\quad 91$

3 Lembar Kuesioner SWOT 94

4 Riwayat Hidup 96 


\section{PENDAHULUAN}

\section{Latar Belakang}

Industri merupakan salah satu sektor yang menghasilkan pendapatan besar bagi suatu kota atau suatu daerah. Pemerintah banyak melakukan pembebasan lahan untuk pembangunan kawasan industri. Kawasan industri merupakan suatu kawasan dengan luas tertentu yang diperuntukkan bagi kegiatan perindustrian. Menurut Dirdjojuwono (2004), kawasan industri memiliki fasilitas peralatan-peralatan pabrik, laboratorium untuk pengembangan, bangunan perkantoran, dan pertamanan (landscape). Selain memberikan keuntungan, kawasan industri juga mengasilkan kerugian bagi lingkungan, yakni penghasil polusi dan limbah.

Ruang terbuka hijau (RTH) adalah ruang yang didominasi oleh tanaman dan vegetasi guna mendukung manfaat langsung atau tidak langsung bagi manusia dan lingkungan sekitar (Purwanto 2007). Ruang terbuka hijau merupakan salah satu aspek yang harus dipenuhi oleh suatu kawasan industri karena fungsinya yang cukup besar dalam meningkatkan ataupun memperbaiki kualitas lingkungan. Dengan adanya RTH, dampak dari polusi udara dan limbah kegiatan industri dapat dikurangi. Selain itu, RTH juga diperlukan untuk rekreasi bagi karyawan. Secara tidak langsung, RTH dapat menyegarkan kembali pikiran karyawan dan mengatasi kemonotonan dari lingkungan kawasan industri.

Kota Cilegon merupakan kota di sebelah barat provinsi Banten yang merupakan salah satu kota industri besar yang berperan penting dalam pembangunan perindustrian, perekonomian dan perdagangan di Provinsi Banten. Kota Cilegon sebagian besar merupakan kawasan industri yang terintegrasi dalam Kawasan Industri Krakatau. Keberadaan ruang terbuka hijau di Kawasan Industri menjadi hal penting yang perlu dipertimbangkan karena suatu urgensi untuk meningkatkan kualitas lingkungan dan kenyamanan bagi karyawan serta masyarakat di sekitar kawasan industri.

Kawasan industri yang cukup luas serta memiliki pengaruh yang besar adalah kawasan industri PT Krakatau Steel. Intensitas kegiatan industri PT. Krakatau Steel sangat tinggi, hal ini berkaitan dengan produk utama yang dihasilkan yaitu bahan baja dan komponen dasar dari baja yang merupakan produk orientasi ekspor dan substitusi impor serta produk bahan kimia. Dari tahun 2011 hingga 2016, PT Krakatau Steel telah menanam pohon-pohon baru dalam upaya meningkatkan ruang terbuka hijau di kawasan industrinya (PT Krakatau Steel 2018).

Hingga saat ini Kawasan Industri Krakatau yang terdiri dari 84 kawasan industri di dalamnya, telah memenuhi 15\% dari RTH Kota Cilegon (PT Krakatau Steel 2018). PT Krakatau Steel sebagai kawasan industri terluas merupakan penyedia RTH terbesar di antara kawasan industri krakatau. Akan tetapi menurut PT Krakatau Steel, RTH di kawasan industri tersebut belum pernah dinilai kualitasnya. Oleh karena itu, penelitian ini bertujuan untuk mengevaluasi kesesuaian RTH secara proporsi dan fungsinya untuk meningkatkan kenyamanan termal. Jika RTH yang ada sudah cukup dan sesuai maka bisa dipertahankan. Sebaliknya jika ternyata RTH yang ada masih kurang atau belum sesuai maka perlu direkomendasikan RTH yang sesuai untuk kawasan industri tersebut. Melalui penelitian ini akan direkomendasikan suatu kondisi RTH yang baik di kawasan 
industri PT Krakatau Steel yang dapat menjadi percontohan bagi kawasan industri lainnya di Kota Cilegon dalam mengelola RTH di kawasan industri.

\section{Tujuan Penelitian}

Penelitian ini bertujuan,

1. Mengevaluasi kenyamanan termal dan kecukupan ruang terbuka hijau di kawasan industri PT Krakatau Steel

2. Mengklasifikasikan ruang terbuka hijau di kawasan industri PT Krakatau Steel

3. Mendapatkan persepsi dan preferensi karyawan dan masyarakat terhadap ruang terbuka hijau di kawasan industri PT Krakatau Steel

4. Mengidentifikasi kesesuaian kenyamanan termal dan kecukupan ruang terbuka hijau di kawasan industri PT Krakatau Steel

5. Membuat rekomendasi perbaikan RTH kawasan industri PT Krakatau Steel

\section{Manfaat Penelitian}

Penelitian ini diharapkan memberikan manfaat yaitu,

1. Menjadi bahan pertimbangan bagi pihak pengelola PT Krakatau Steel dalam pengembangan RTH di kawasan industri.

2. Memberikan wawasan bagi masyarakat mengenai peranan ruang terbuka hijau di kawasan industri.

3. Hasil penelitian menjadi rekomendasi mengenai ruang terbuka hijau di kawasan industri

\section{Kerangka Pikir}

Kota Cilegon memiliki banyak perusahaan industri yang berada dalam kawasan industri terpadu. Kawasan industri PT Krakatau Steel merupakan kawasan industri tertua dan keberadaannya mempengaruhi industri pengolahan baja lainnya. Penggunan ruang di kawasan industri harus disesuaikan dengan perundangundangan, termasuk proporsi keberadaan Ruang Terbuka Hijau. Ruang Terbuka Hijau dapat memperbaiki kualitas lingkungan dari dampak polusi dan limbah kegiatan industri. Salah satu dampak kegiatan industri yaitu peningkatan suhu udara sehingga tidak nyaman bagi manusia. Ruang Terbuka Hijau dapat menurunkan suhu udara sehingga tercapai kenyamanan termal bagi manusia. Ruang terbuka hijau juga dapat menjadi area bagi karyawan untuk menyegarkan pikiran dan menghirup udara segar. Selain itu, ruang terbuka hijau dapat berupa kawasan penyangga yang mencegah dampak kegiatan industri menjangkau lingkungan masyarakat. Melalui evaluasi ini diharapkan dapat memberikan rekomendasi ruang terbuka hijau yang sesuai bagi kawasan industri PT Krakatau Steel. Kerangka pikir permasalahan ini dapat dilihat pada Gambar 1. 


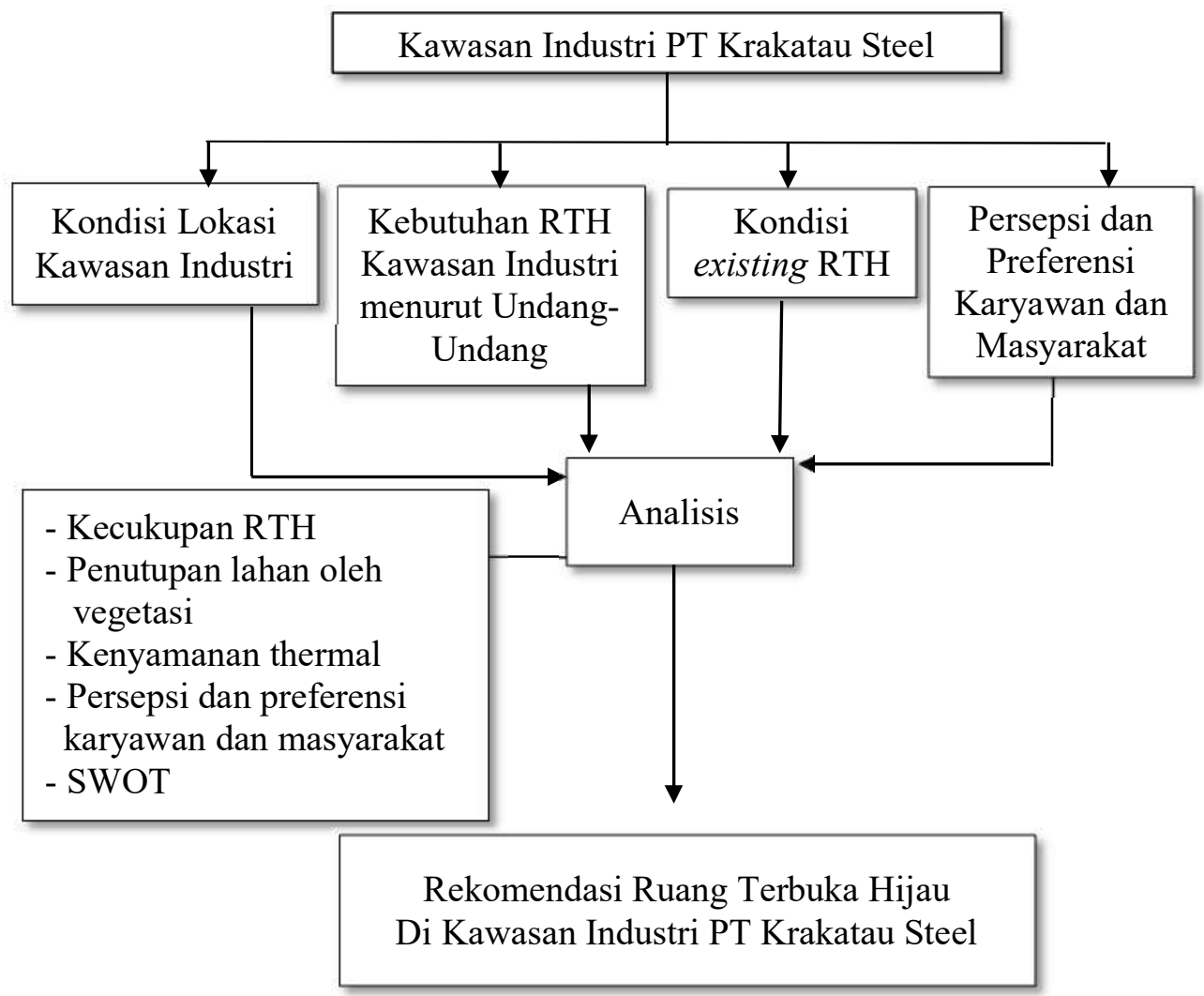

Gambar 1 Kerangka Pikir Penelitian

\section{TINJAUAN PUSTAKA}

\section{Kawasan Industri}

Menurut Peraturan Pemerintah No.24 tahun 2009, Industri adalah kegiatan ekonomi yang mengolah bahan mentah, bahan baku, bahan setengah jadi menjadi barang dengan nilai yang lebih tinggi untuk penggunaannya, termasuk kegiatan rancang bangun dan perekayasaan industri. Industri adalah aset yang berharga bagi daerah ataupun negara karena pendapatannya yang cukup besar. Pengklasifikasian kegiatan industri didasarkan pada kriteria yaitu berdasarkan bahan baku, tenaga kerja, pangsa pasar, modal, atau jenis teknologi yang digunakan (Dwiputri 2012). Berdasarkan SK Menteri Perindustrian No.19/M/I/1986 dalam Nugroho 2009, kegiatan industri diklasifkasikan menjadi empat, yaitu: industri kimia dasar (contoh: pupuk, kertas), industri mesin dan logam dasar (contoh: kendaraan bermotor, tekstil), industri kecil (contoh: minyak goreng, makanan ringan), dan aneka industri (contoh: makanan, pakaian).

Kawasan Industri adalah suatu tempat pemusatan kegiatan industri yang dilengkapi dengan prasarana dan sarana yang disediakan dan dikelola oleh 
perusahaan kawasan industri (Kwanda 2000). Menurut Peraturan Pemerintah No.24 tahun 2009, pembangunan kawasan industri bertujuan untuk:

a. Mengendalikan pemanfatan ruang.

b. Meningkatkan upaya pembangunan kawasan industri yang berwawasan lingkungan.

c. Mempercepat pertumbuhan industri di daerah.

d. Meningkatkan daya saing industri.

e. Meningkatkan daya saing investasi.

f. Memberikan kepastian lokasi dalam perencanaan dan pembangunan infrastruktur yang terkoordinasi antar sektor terkait.

Dalam merencanakan suatu kawasan industri, pemerintah melalui Menteri

Perindustrian telah menentukan Standar Teknis Kawasan Industri yaitu melalui Surat Keputusan Menteri Perindustrian Nomor: 291/M/SK/10/1989 tanggal 28 Oktober 1989. Secara garis besar standar teknis mencakup beberapa hal yaitu:

1. Komposisi penggunaan lahan

a. Kapling industri : Maximum 70\%

b. Ruang terbuka hijau termasuk daerah penyangga : Minimum $10 \%$

c. Prasarana dan sarana: Luas tanah sisa $(20 \%)$

2. Prasarana yang wajib disediakan antara lain :

a. Jaringan jalan lingkungan: satu jalur dengan dua arah, lebar perkerasan minimum 8 meter atau dua jalur dengan dua arah, lebar perkerasan minimal $2 \times 7$ meter

b. Saluran pembuangan air hujan (drainase)

c. Instalasi penyediaan air bersih bersumber dari PAM dan/atau diusahakan sendiri

d. Instalasi penyediaan dan jaringan distribusi tenaga listrik dengan sumber PLN dan/atau diusahakan sendiri

e. Jaringan telekomunikasi

f. Instalasi pengelolaan air limbah industri

g. Penerangan jalan

h. Unit perkantoran perusahaan kawasan industri

i. Unit pemadam kebakaran

Diluar prasarana yang diwajibkan, dapat pula menyediakan prasarana seperti

TPS limbah padat dan pagar kawasan industri.

3. Sarana

Sarana yang dapat disediakan yaitu: kantin, poliklinik, tempat ibadah, rumah penginapan sementara, fitness center, halte, pos keamanan, perkantoran untuk bank, pos dan wartel.

\section{Dampak Kegiatan Industri}

Kegiatan perindustrian merupakan salah satu kegiatan manusia yang sering menimbulkan dampak terhadap lingkungan yang menyebabkan kualitas lingkungan berubah. Dampak negatif akibat kegiatan industri dapat mengganggu keseimbangan lingkungan, dapat dilihat dari terjadinya masalah pencemaran udara, pencemaran air, dan pecemaran daratan. Menurut Daryanto dalam Paramitha (2013), setiap pencemaran memiliki derajat pencemaran atau tahap pencemaran yang berbeda 
berdasarkan pada: (1) konsentrasi zat pencemar, (2) waktu tercemarnya, dan (3) lamanya kontak antara bahan pencemar dan lingkungan.

Kegiatan perindustrian tidak terlepas dari sisa material buangan yang disebut limbah. Menurut Kristanto (2004), limbah adalah buangan yang kehadirannya pada suatu saat dan tempat tertentu tidak dikehendaki lingkungan karena tidak memiliki nilai ekonomi. Limbah yang mengandung bahan polutan yang memiliki sifat racun dan berbahaya dikenal dengan limbah B-3, yang dinyatakan sebagai bahan yang dalam jumlah relatif sedikit tetapi berpotensi untuk merusak lingkungan hidup dan sumberdaya. Beberapa kriteria berbahaya dan beracun telah ditetapkan, antara lain mudah terbakar, mudah meledak, korosif, bersifat sebagai oksidator dan reduktor yang kuat, mudah membusuk, dan lain-lain.

Penggunaan mesin dalam kegiatan industri tentunya menghasilkan gas buangan yang akan bercampur dengan udara. Pencemaran udara diartikan sebagai adanya bahan-bahan atau zat-zat asing di dalam udara yang menyebabkan perubahan susunan komposisi udara dari keadaan normalnya (Wardhana 2004). Kegiatan industri diperkirakan juga menimbulkan eksternalitas negatif bagi lingkungan hidup berupa pencemaran dan kerusakan lingkungan (Resosudarmo, et al. 2000).

Akibat yang ditimbulkan oleh pencemaran udara ternyata sangat merugikan. Pada umunya udara yang telah tercemar oleh partikel dapat menimbulkan berbagai macam penyakit saluran pernapasan atau pneumoconiosis (Wardhana 2004). Pencemaran tersebut tidak hanya mempunyai akibat langsung terhadap kesehatan manusia saja, akan tetapi juga dapat merusak lingkungan lainnya, seperti hewan, tanaman, bangunan gedung, dan lain sebagainya.

Sumber pencemar udara dari kegiatan industri yang dilepaskan ke udara antara lain COx, NOx, SOx, SPM (Suspended Particular Matter), Ox, dan berbagai logam berat. Berlebihnya tingkat konsentrasi zat pencemar hingga melampui ambang batas toleransi yang diperkirakan akan mempunyai dampak negatif yang berbahaya terhadap lingkungan, baik bagi manusia, tumbuh-tumbuhan, hewan, dan rusaknya benda-benda (material), serta berpengaruh terhadap kualitas air hujan (hujan asam), yang berakibat pada mata rantai berikutnya, yaitu pada ekosistem flora dan fauna (Budiyono 2001).

Dampak kesehatan yang diakibatkan oleh pencemaran udara terhadap manusia berbeda-beda antar individu. Populasi yang paling rentan adalah kelompok individu berusia lanjut dan balita. Menurut penelitian di Amerika Serikat, kelompok balita mempunyai kerentanan enam kali lebih besar jika dibandingkan dengan orang dewasa. Kelompok balita lebih rentan karena mereka lebih aktif dan dengan demikian menghirup udara lebih banyak, sehingga mereka lebih banyak menghirup zat-zat pencemar (Farida 2004).

Berdasarkan hasil penelitian Ekawati (1998) menunjukkan bahwa pencemaran udara secara nyata berpengaruh pada kerusakan (abnormalitas) sel daun beberapa jenis tanaman. Terjadinya pertambahan atau pengurangan ukuran sel merupakan indikasi terjadinya penambahan atau pengurangan massa sel. Hal ini merupakan respon tanaman untuk mempertahankan keseimbangan fungsi fisiologis, terutama pada sel daun sebagai tempat terjadinya fotosintesis. Perubahan bentuk sel, variasi penambahan atau kenaikan maupun penurunan ukuran sel, menunjukkan respon dari masingmasing sel tanaman terhadap tekanan yang diberikan oleh lingkungan berupa udara yang tercemar. 


\section{Ruang Terbuka Hijau}

Ruang terbuka hijau merupakan ruang yang tidak terbangun yang memiliki kekuatan untuk membentuk karakter suatu kota (Simonds 1983). Ruang terbuka hijau di kota harus dikembangkan untuk menjaga kualitas lingkungan sekitar. Ruang terbuka hijau menjadi pelembut suasana kota yang dipenuhi bangunan dan kendaraan yang melintas secara intensif. Tanpa adanya Ruang Terbuka Hijau (RTH), suhu kota meningkat dan menjadi urban heat island yang tidak dapat memberikan kenyamanan bagi masyarakat.

Tujuan penyelenggaraan ruang terbuka hijau (RTH) menurut Departemen PU (2008) berdasarkan Peraturan Menteri Pekerjaan Umum Nomor 5/PRT/M/2008 tentang Pedoman Penyediaan dan Pemanfaatan Ruang Terbuka Hijau di Kawasan Perkotaan adalah:

1. Menjaga ketersediaan lahan sebagai kawasan resapan air;

2. Menciptakan aspek planologis perkotaan melalui keseimbangan antara lingkungan alam dan lingkungan binaan yang berguna untuk kepentingan masyarakat;

3. Meningkatkan keserasian lingkungan perkotaan sebagai sarana pengaman lingkungan perkotaan yang aman, nyaman, segar, indah dan bersih.

RTH memiliki berbagai macam bentuk dan penggunaan. RTH tersusun dari beranekaragam spesies tanaman dan strata vegetasi yang terdiri dari jenis pohon, perdu, semak, ground cover, rumput. Menurut Undang-undang No. 26 tahun 2007 RTH dibagi berdasarkan beberapa kategori: berdasarkan bobot kealamiannya RTH dibagi menjadi RTH alami (habitat liar, kawasan lindung) dan RTH binaan (lapangan olahraga, pertamanan, pemakaman), berdasarkan sifat dan karakter ekologisnya RTH dibagi menjadi RTH kawasan dan RTH jalur, berdasarkan kawasan fungsional RTH dibagi menjadi: RTH perdagangan, RTH perindustrian, RTH pemukiman, RTH pertamanan, dan RTH kawasan khusus, berdasarkan status kepemilikannya RTH dibagi menjadi RTH publik (dikelola oleh pemerintah) dan RTH privat.

Pada dasarnya RTH dimaksudkan untuk menekan efek negatif yang ditimbulkan lingkungan terbangun seperti di perkotaan, yaitu peningkatan temperatur udara, penurunan tingkat peresapan air dan kelembaban udara, polusi dan lain sebagainya. Vegetasi memiliki peranan sangat besar dalam kehidupan. Dari berbagai peranan vegetasi dan manfaat vegetasi, maka manfaat dan fungsi penghijauan atau ruang terbuka hijau (RTH), adalah (Amir dalam Hendrawan, 2003):

a. Paru-paru kota: tanaman sebagai elemen hijau pada pertumbuhannya menghasilkan zat asam $\left(\mathrm{O}_{2}\right)$ yang sangat diperlukan bagi makhluk hidup untuk pernapasan.

b. Pengatur lingkungan (mikro): vegetasi akan menimbulkan lingkungan setempat menjadi sejuk, nyaman, dan segar.

c. Pencipta lingkungan hidup: penghijauan dapat menciptakan ruang bagi makhluk hidup di alam yang memungkinkan terjadinya interaksi secara alamiah.

d. Penyeimbang alam (edapis): merupakan pembentukan tempat hidup alami bagi satwa yang hidup di sekitarnya. 
e. Perlindungan bagi kondisi fisik alami sekitarnya: seperti angin kencang, terik matahari, gas, atau debu.

f. Mengurangi polusi udara: vegetasi dapat menyerap polutan tertentu.

g. Vegetasi dapat menyaring debu dengan tajuk dan kerimbunan dedaunannya.

h. Mengurangi polusi air: vegetasi dapat membantu membersihkan air.

i. Mengurangi polusi suara (kebisingan): vegetasi dapat menyerap suara.

j. Keindahan (estetika): unsur-unsur penghijauan yang direncanakan dengan baik dan menyeluruh akan menambah keindahan kota.

k. Kesehatan: warna dan karakter tumbuhan dapat digunakan untuk terapi mata dan jiwa.

1. Nilai pendidikan: komunitas vegetasi yang ditanam dengan keanekaragaman jenis dan karakter akan memberikan nilai ilmiah sehingga sangat bermanfaat untuk pendidikan, seperti hutan kota.

m. Sosial, politik, dan ekonomi: tumbuhan mempunyai nilai sosial yang tinggi.

n. Penghijauan perkotaan: menjadi indikator atau petunjuk bagi lingkungan, kemungkinan ada hal-hal yang membahayakan yang terjadi atas pertumbuhan dan perkembangan kota.

Menurut Hasni (2009), RTH memiliki berbagai fungsi seperti edaphis, orologis, hidrologis, klimatologis, higienis, edukatif, estetis, dan sosial ekonomis. Fungsi tersebut dapat dipenuhi oleh semua jenis RTH yang ada di perkotaan, dengan pengertian sebagai berikut

a. Fungsi edaphis yaitu sebagai tempat hidup satwa dan jasad renik lainnya, dapat dipenuhi dengan penanaman pohon yang sesuai.

b. Fungsi hidro-orologis adalah perlindungan terhadap kelestarian tanah dan air.

c. Fungsi klimatologis adalah terciptanya iklim mikro sebagai efek dari proses fotosintesis dan respirasi tanaman.

d. Fungsi protektif: melindungi dari gangguan angin, bunyi, dan terik matahari melalui kerapatan dan kerindangan pohon perdu dan semak.

e. Fungsi higienis adalah kemampuan RTH untuk mereduksi polutan baik di udara maupun di air.

f. Fungsi edukatif adalah RTH bisa menjadi sumber pengetahuan masyarakat tentang berbagai hal, misalnya macam dan jenis vegetasi, asal muasalnya, nama ilmiahnya, manfaat serta khasiatnya.

g. Fungsi estetis adalah kemampuan RTH untuk menyumbangkan keindahan pada lingkungan sekitarnya, baik melalui keindahan warna, bentuk, kombinasi tekstur, bau-bauan ataupun bunyi dari satwa liar yang menghuninya.

h. Fungsi sosial ekonomis adalah RTH sebagai tempat berbagai kegiatan sosial dan tidak menutup kemungkinan memiliki nilai ekonomi seperti pedagang tanaman hias.

\section{RTH pada Kawasan Industri}

Kegiatan industri merupakan kegiatan yang berdampak langsung terhadap lingkungan. Dampak tersebut berupa polusi udara, dan limbah baik berbentuk padat ataupun cair. Keberadaan ruang terbuka hijau di kawasan industri dapat mengurangi polusi. Tanaman mengurangi polusi udara dengan absorpsi yaitu 
melalui daun, cabang, dan tangkai serta struktur permukaan menangkap partikel yang tercuci oleh pencucian udara. Menurut Grey dan Deneke (1978), tanaman yang ditanam untuk mengurangi polusi harus memperhatikan hal berikut:

1. Tanaman harus tegak lurus arah angin

2. Pola tanaman terbuka dan permeable harus dikombinasikan dengan pembatas yang rapat

3. Tanaman harus secara konsentris mengelilingi sumber polusi

Karyawan di kawasan industri membutuhkan RTH untuk menyegarkan kembali pikiran karyawan dan mengatasi kemonotonan dari lingkungan kawasan industri. Karyawan dapat berekreasi dalam taman kawasan industri saat waktu istirahat atau selepas melakukan pekerjaan. Taman ini terlindungi secara alami dari kebisingan, debu, dan gas buangan industri serta menjadi tempat memperoleh oksigen yang diperlukan bagi pernapasan. Menurut Fakuara (1978) dalam Jahara (2002), jenis tanaman yang dipilih adalah yang mempunyai sifat berikut:

a. Jika bertujuan meredam debu udara

1. Mempunyai stomata yang banyak

2. Mempunyai tajuk yang rimbun dan rapat

3. Mempunyai daya tahan yang tinggi

b. Jika bertujuan menyerap gas

1. Mempunyai stomata yang banyak

2. Mempunyai ketahanan tinggi terhadap gas tertentu

3. Mempunyai tingkat pertumbuhan yang cepat

4. Tahan terhadap serangan angin

Kawasan industri juga tidak terlepas dari keadaan lingkungan yang berpenduduk, baik dalam bentuk permukiman, pertokoan, pertanian, dan sebagainya. Oleh karena itu, perlu dibuatnya RTH penyangga berupa green belt agar debu dan polusi dari kawasan industri sebagian besar tidak masuk ke lingkungan yang berpenduduk. Tanaman dipilih berdasarkan perhitungan gerakan angin yang bergerak di sekitar kawasan. Penanaman harus memperhatikan tinggi gerakan angin serta jarak daerah yang perlu dilindungi (Jahara 2002).

Menurut Prasetyo, et.al. dalam Tinambunan (2006), beberapa penelitian telah dilakukan untuk menguji kemampuan ruang terbuka hijau dapat mengurangi karbon dioksida. Kemampuan tanaman dalam menyerap gas karbon dioksida bermacammacam. Menurutnya, ruang terbuka hijau yang mempunyai berbagai macam tipe penutupan vegetasi memiliki kemampuan atau daya serap terhadap karbon dioksida yang berbeda. Tipe penutupan vegetasi tersebut berupa pohon, semak belukar, padang rumput, sawah. Daya serap berbagai macam tipe vegetasi terhadap polusi udara dapat dilihat pada tabel berikut ini.

Tabel 1 Daya Serap Ruang Terbuka Hijau terhadap Polusi Udara

\begin{tabular}{clc}
\hline No. & Jenis Tutupan Lahan / Vegetasi & (Ton/ha/th) \\
\hline 1 & Pohon & 569,07 \\
\hline 2 & Semak Belukar & 55 \\
\hline 3 & Padang Rumput & 12 \\
\hline 4 & Sawah & 12 \\
\hline
\end{tabular}

Sumber: Tinambunan (2006) 


\section{Hubungan RTH dengan Kenyamanan Termal}

Ruang terbuka hijau tidak hanya memberikan manfaat dalam aspek ekologi, sosial, budaya, ekonomi, dan estetika, namun juga aspek iklim mikro di wilayah tersebut. Effendy (2014) menjelaskan bahwa terjadi peningkatan suhu udara pada wilayah yang mengalami penurunan RTH. Peningkatan suhu udara mempengaruhi kenyamanan termal bagi populasi yang tinggal di wilayah tersebut. Salah satu metode yang dapat digunakan untuk mengkaji tingkat kenyamanan suatu wilayah adalah metode Temperature Humidity Index (THI). Metode ini menghasilkan suatu indeks untuk menetapkan efek dari kondisi panas terhadap kenyamanan manusia berdasarkan unsur suhu dan kelembaban udara.

Perubahan suhu, wilayah bervegetasi, dan kenyamanan termal saling berkaitan. Gomez et al. (2004) menjelaskan bahwa areal bervegetasi memiliki peranan penting dalam mempengaruhi albedo dan nilai dari radiasi surya yang sampai ke wilayah perkotaan. Hal tersebut berkorelasi positif terhadap kenyamanan manusia jika dilihat dari indeks kenyamanan yang dihasilkan.

Semakin banyak kawasan terbangun di kawasan industri berupa beton dan perkerasan lain akan menyebabkan lebih banyak energi sinar matahari yang diubah menjadi energi panas, sehingga suhu semakin meningkat. Pengurangan RTH suatu kawasan akan berdampak pada berkurangnya pepohonan yang berfungsi menyerap $\mathrm{CO} 2$ dan gas-gas polutan, mengurangi produksi O2 sehingga dapat menurunkan kesejukan dan perkerasan tidak dapat berdiri sendiri dalam suatu lanskap (Zahra et al. 2014).

Konsep mengenai zona hijau (green zone) yang mempengaruhi kenyamanan juga telah dikaji oleh Setyawati (2008) di kota Semarang. Setyawati (2008) menjelaskan bahwa tegakan vegetasi yang kurang sebagai perindang yang ditanam di sepanjang jalan menyebabkan keadaan iklim mikro yang cukup panas dan kering.

Penelititan tentang hubungan penggunaan lahan terhadap suhu udara yang dilakukan oleh Adhayani (2005) pada Kota Cibinong menunjukkan bahwa perubahan penggunaan lahan RTH menjadi pemukiman akan memberikan kontribusi terhadap peningkatan suhu udara sebesar $1.5^{\circ} \mathrm{C}$. Meskipun hasil penelitian tersebut menggolongkan Kota Cibinong kedalam kategori nyaman, tetapi jika ruang terbangun diperluas maka akan meningkatkan suhu udara yang pada akhirnya juga akan menyebabkan ketidaknyamanan terjadi.

Penelitian yang sejenis juga dilakukan di Kota Surabaya. Luas daerah Kota Surabaya yang memiliki THI lebih dari $26^{\circ} \mathrm{C}$ mengalami peningkatan dari 16.082 Ha pada tahun 1994 menjadi 31.948 pada tahun 2002. Hal tersebut disebabkan oleh pengurangan RTH sebesar 9.2\% pada periode yang sama (Tursilowati 2007).

Menurut penelitian Effendy (2014), Secara umum hasil yang diperoleh menunjukkan bahwa kawasan RTH akan memberikan pengaruh cooling effect di daerah sekitar sehingga suhu udara yang dimiliki akan lebih rendah dibandingkan dengan kawasan non-RTH. Kondisi lingkungan di RTH seperti kerapatan penutupan kanopi pohon di sekitar area, kondisi lalu lintas di sekitar RTH, dan objek di sekitar dan di dalam RTH menjadi faktor yang menyebabkan berkurangnya pengaruh cooling effect di daerah tersebut. 


\section{Evaluasi}

Evaluasi merupakan suatu tindakan yang dilakukan untuk menelaah atau menduga hal-hal yang sudah diputuskan untuk mengetahui kelemahan dan kelebihan keputusan tersebut. Selanjutnya ditentukan langkah-langkah alternatif perbaikannya bagi kelemahan tersebut (Vitasari 2004).

Porteus (1983) menyatakan bahwa evaluasi lanskap merupakan salah satu metode estetika lanskap kuantitatif yang menyertakan tenaga ahli. Dasar pemikiran evaluasi adalah bahwa seseorang dapat melakukan penilaian estetika lanskap yang berharga, fungsional dan dapat diterima umum. Evaluasi melibatkan penjelasan sejumlah faktor yang mungkin mempengaruhi variasi kualitas lanskap, skala untuk mengukur faktor tersebut dan mengembangkan suatu sistem pembobotan untuk menentukan bermacam-macam penekanan pada faktor yang berbeda-beda.

Pada hakekatnya, evaluasi diyakini sangat berperan dalam upaya meningkatkan kualitas operasional suatu program dan berkontribusi penting dalam memandu pembuat kebijakan di seluruh strata organisasi. Dengan menyusun desain evaluasi yang baik dan menganalisis hasilnya dengan tajam, kegiatan evaluasi dapat memberi gambaran tentang bagaimana kualitas operasional program, layanan, kekuatan dan kelemahan yang ada, efektivitas biaya serta arah produktif yang potensial untuk masa depan (Hidayat 2010).

\section{METODOLOGI}

\section{Lokasi Penelitian}

Penelitian ini dilaksanakan di Kawasan Industri atau Kawasan Plant PT Krakatau Steel, secara administratif terletak pada Kecamatan Cilegon dan Ciwandan, Kota Cilegon. Kawasan industri PT Krakatau Steel merupakan bagian dari Kawasan Industri Krakatau terletak di sebelah timur pesisir pulau Jawa dan dekat dengan Selat Sunda (Gambar 2 dan Gambar 3). Kawasan Industri PT Krakatau Steel terbagi dalam beberapa kawasan pabrik (plant), dan di setiap masing-masing kawasan pabrik memiliki RTH yang cukup memadai.

Lokasi yang dipilih sebagai tempat penelitian adalah RTH yang terdapat di kawasan industri tersebut yaitu taman, lapangan, jalur hijau, dan green belt. Keberadaan taman di kawasan industri berfungsi sebagai pelembut kemonotonan kawasan industri dan peningkatan kualitas estetika kawasan. Keberadaan lapangan berfungsi sebagai tempat pelaksanaan aktifitas untuk hari-hari besar serta sarana berolahraga bagi karyawan. Jalur hijau yang terdapat di kawasan tersebut yaitu jalur hijau jalan, jalur hijau sempadan sungai, dan jalur hijau rel kereta api. Green belt terdapat di setiap bagian plant, berfungsi untuk mengurangi penyebaran polusi udara, serta memodifikasi iklim mikro. Batas wilayah PT Krakatau Steel adalah sebagai berikut:

Utara : Kawasan Industri Krakatau

Selatan : Jalan Raya Anyer-Cilegon dan Permukiman

Barat : PT Krakatau Posco 
Timur $\quad$ : Kawasan Industri Krakatau

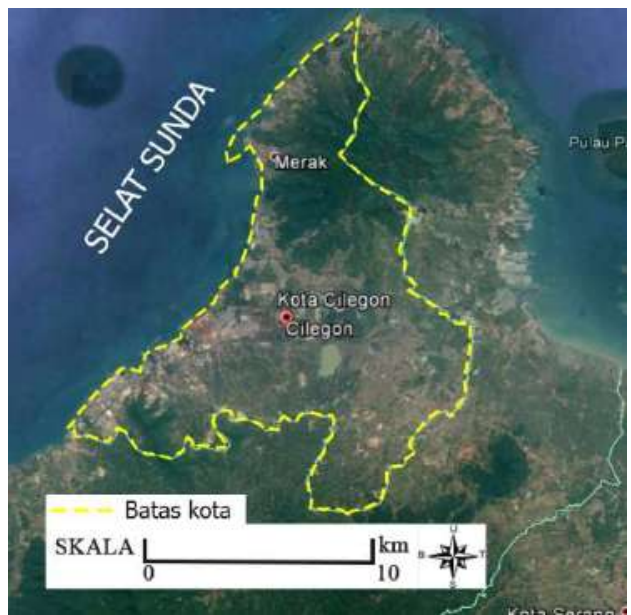

Gambar 2 Kota Cilegon

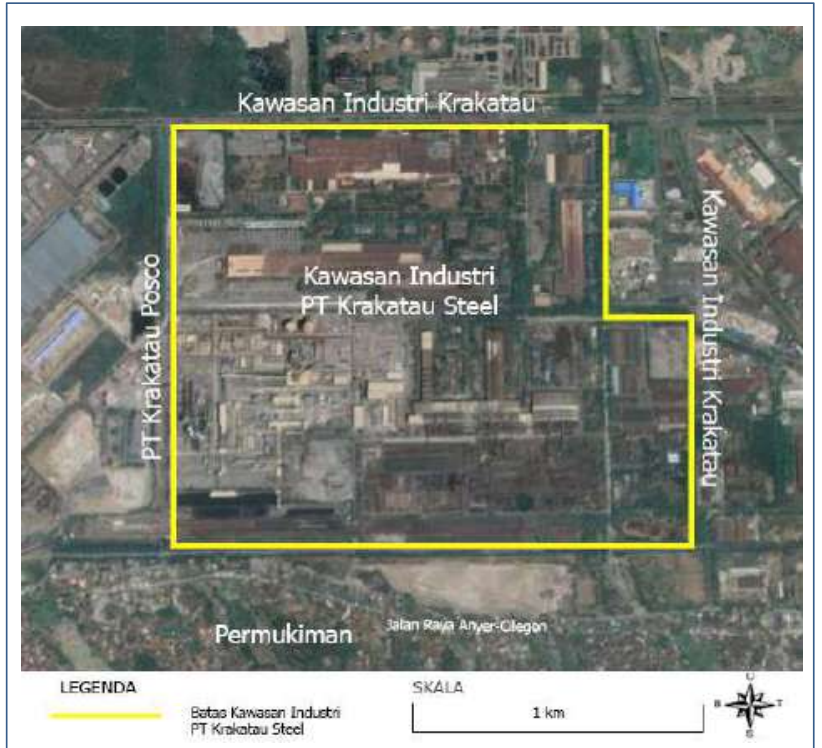

Gambar 3 Kawasan Industri PT Krakatau Steel

\section{Waktu Penelitian}

Penelitian dilakukan selama enam bulan dimulai dari bulan November 2017 sampai Mei 2018. Penelitian dimulai dari tahap persiapan penelitian hingga sintesis berupa penyusunan rekomendasi pengembangan RTH sebagaimana terinci pada tabel 2. Tahap persiapan dan studi pustaka awal pada bulan November hingga Desember 2017, pengumpulan data dilakukan pada bulan Januari hingga Februari 2018, analisis data dilakukan pada bulan Maret hingga April 2018, dan sintesis dilakukan pada bulan Mei 2018. 
Tabel 2 Jenis Kegiatan dan Waktu Pelaksanaan

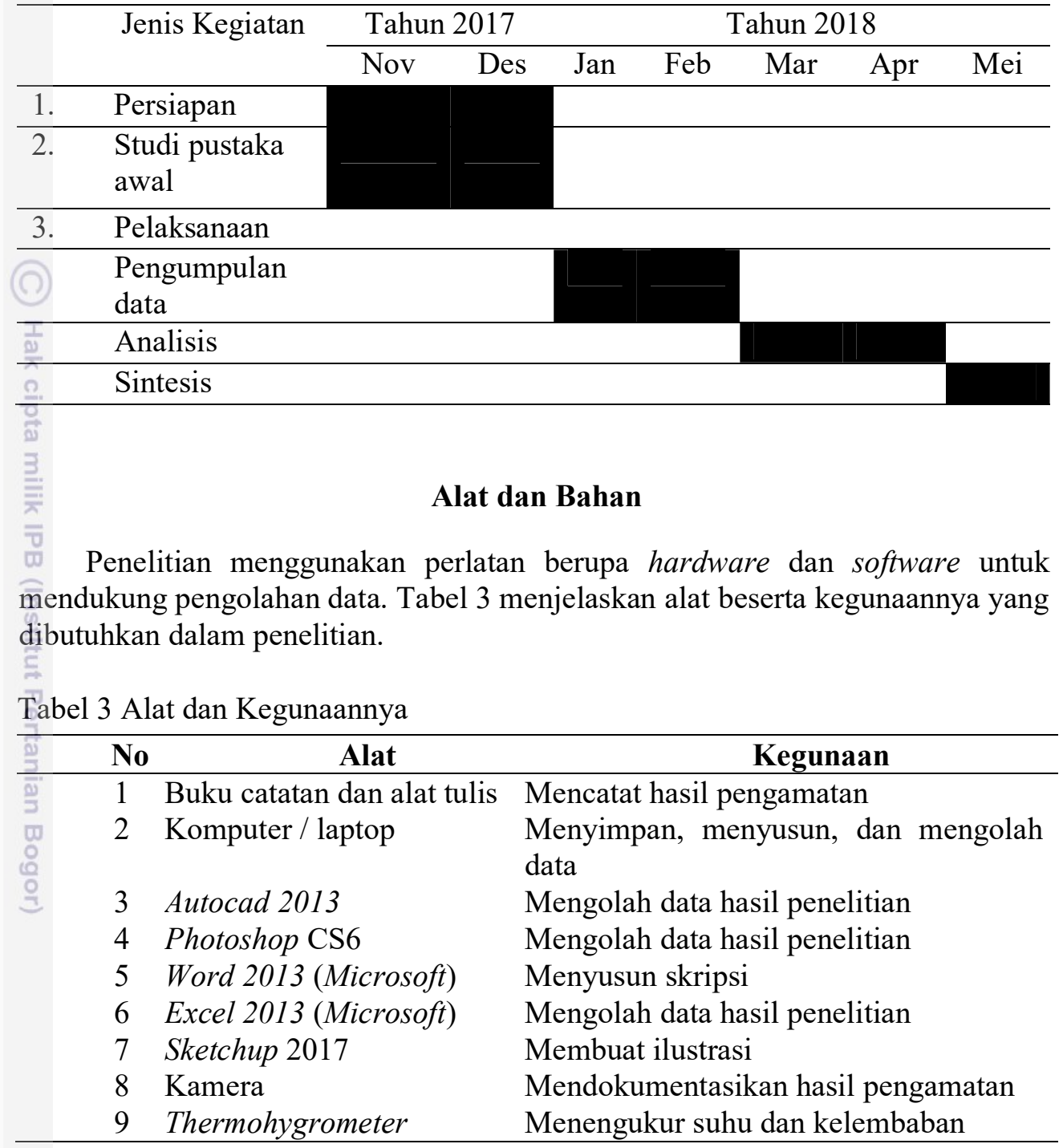

Bahan yang digunakan untuk penelitian ini terdiri dari dua sumber data yaitu data primer dan data sekunder. Data primer didapatkan dari hasil pengamatan langsung di lapangan melalui pengukuran suhu dan kelembaban serta penyebaran kuesioner sebagai bahan untuk analisis preferensi masyarakat, karyawan, dan data untuk analisis SWOT. Data sekunder didapatkan dari instansi terkait dan studi literatur. Tabel 4 menunjukkan jenis dan sumber data yang diperlukan sebagai bahan penelitian.

Tabel 4 Jenis dan Sumber Data

\begin{tabular}{llll}
\hline & No & Jenis Data & \multicolumn{1}{c}{ Sumber Data } \\
\hline & 1 & Peta Kota Cilegon & Bappeda \\
& 2 & Peta Kawasan Industri & Instansi terkait \\
& 3 & Citra Kawasan Indzaustri & Instansi terkait \\
\hline
\end{tabular}


Tabel 4 (lanjutan) Jenis dan Sumber Data

\begin{tabular}{cll}
\hline 4 & Iklim & BMKG \\
5 & Tanah & Instansi terkait \\
6 & Topografi & Instansi terkait \\
7 & Hidrologi & Instansi terkait \\
8 & Suhu dan kelembaban & Pengukuran \\
9 & Distribusi RTH & Instansi terkait, survey lapang \\
10 & Kualitas Air & Instansi terkait \\
11 & Kualitas Udara & Instansi terkait \\
12 & Limbah buangan & Instansi terkait, survey lapang \\
13 & Vegetasi & \\
14 & Masyarakat (aktivitas, persepsi dan Wawancara, kuesioner \\
& preferensi terhadap tapak, pengetahuan \\
& terhadap RTH) \\
15 & Karyawan (aktivitas, pengetahuan Wawancara, kuesioner \\
& terhadap RTH, persepsi dan preferensi \\
& terdahap RTH)
\end{tabular}

\section{Batasan Penelitian}

Penelitian dilakukan di kawasan industri PT Krakatau Steel. Penelitian dilakukan untuk mengetahui penggunaan ruang, proporsi luasan dan kondisi Ruang Terbuka Hijau (RTH), kenyamanan termal, serta persepsi dan preferensi masyarakat terhadap kawasan industri dan RTH yang ada. Pada penelitian ini dilakukan evaluasi terhadap kesesuaian RTH dilihat dari proporsi dan fungsinya untuk meningkatkan kenyamanan termal. Hasil akhir dari penelitian ini adalah usulan rekomendasi yang sesuai dengan kondisi yang ada. Jika RTH yang ada belum sesuai maka dilakukan perbaikan atau penataan kembali, sebaliknya jika RTH yang ada sudah sesuai dengan kondisi yang ada maka usulan yang diberikan lebih mengarah pada mempertahankan disertai dengan peningkatan kualitasnya.

\section{Metode Penelitian}

\section{Tahap Persiapan}

Pada tahap ini dilakukan penyusunan usulan dan tujuan penelitian, pembuatan proposal yang juga sekaligus mempersiapkan alat dan teknis kunjungan ke lokasi, serta perizinan administrasi yang terdiri dari pembuatan surat izin penelitian.

\section{Tahap Pelaksanaan}

\section{a. Pengumpulan Data}

Kegiatan ini meliputi pengumpulan data awal baik secara langsung (pada tapak) atau menggunakan data yang sudah ada dari instansi terkait. Data yang dikumpulkan dapat berupa data fisik maupun non-fisik. Data fisik berupa peta penggunaan lahan, data citra, data iklim, tanah dan geologi, topografi, hidrologi, vegetasi, serta suhu dan kelembaban. Data non-fisik berupa persepsi dan preferensi 
masyarakat dan karyawan terhadap kondisi RTH di kawasan industri PT Krakatau Steel. Data-data tersebut selanjutnya digunakan sebagai dasar analisis dan penyusunan rekomendasi RTH. Untuk metode pengambilan data dilakukan dengan cara sebagai berikut:

1. Survey lapangan yaitu melakukan pengamatan langsung kondisi kawasan industri, jenis dan tata letak bangunan, limbah industri, serta kondisi RTH yang ada.

2. Wawancara untuk memperoleh data dan informasi mengenai persepsi maupun preferensi masyarakat terhadap kawasan industri, pengetahuan mengenai RTH, dan kebutuhan RTH di kawasan industri bagi masyarakat.

3. Pengisian kuesioner oleh karyawan mengenai kondisi sekitar kawasan industri, dampak yang ditimbulkan oleh kegiatan industri, pengetahuan mengenai RTH, kebutuhan terhadap RTH, serta kondisi RTH yang ada saat ini (Lampiran 1).

4. Studi pustaka untuk mendapatkan data yang tidak bisa diambil secara langsung dan untuk mempelajari lebih jelas data yang sudah dikumpulkan.

b. Analisis data

Data yang sudah dikumpulkan selanjutnya dianaIisis untuk menilai kondisi RTH di kawasan industri PT Krakatau Steel. Analisis yang dilakukan meliputi:

1) Analisis Kecukupan Ruang Terbuka Hijau (RTH)

Analisis ini berfokus pada identifikasi luasan ruang terbuka hijau eksisting tapak, yaitu dengan membandingkan luas ruang terbuka hijau yang sudah ada dengan standar yang telah ditetapkan. Analisis terhadap RTH dilakukan secara deskriptif. Standar RTH yang ditetapkan tersebut mengacu pada:

1. UU No. 26 Tahun 2007 tentang Penataan Ruang menyatakan bahwa luasan ruang terbuka hijau kota minimal sebesar $30 \%$ dengan $20 \%$ milik publik dan $10 \%$ privat.

2. Berdasarkan Peraturan Menteri Perindustrian No.40 tahun 2016 tentang Pedoman Teknis Kawasan Industri, yaitu Ruang terbuka hijau pada kawasan yaitu minimal 10\% dari luas area. Standar RTH yang harus berada di kawasan industri berupa jalur hijau, green belt, taman, dan perimeter.

3. RTRW Kota Cilegon 2010-2030 mengenai ketentuan umum zonasi kawasan perindustrian yang menyatakan bahwa pengembangan kawasan perindustrian harus dilengkapi taman-taman lingkungan dan jalur hijau (green belt) sebagai penyangga atau buffer antar fungsi kawasan, serta sarana pengelolaan limbah.

Penilaianya yaitu hasil pengamatan lapang dan data sekunder Kawasan Industri PT Krakatau Steel mengenai proporsi luas RTH dibandingkan dengan ketentuan persyaratan RTH untuk Kawasan Industri berdasarkan Peraturan Menteri Perindustrian No.40 tahun 2016 tentang Pedoman Teknis Kawasan Industri, UU No.26 Tahun 2007 tentang Penataan Ruang, dan RTRW Kota Cilegon Tahun 20102030 Analisis dilakukan untuk menilai kesesuaian proporsi luas RTH.

\section{2) Analisis Kenyamanan Termal}

Analisis ini bertujuan untuk mengetahui tingkat kenyamanan pengguna melalui perhitungan suhu dan kelembaban. Kemudian nilai THI pada masingmasing ruang terbuka hijau akan dibandingkan antara kondisi tanpa naungan pohon dengan di bawah naungan pohon. Kenyamanan dinilai dari hasil pengukuran suhu dan kelembaban udara yang dilakukan pada enam lokasi RTH di kawasan industri yaitu pada taman Masjid HSM, taman CRM, Jalur hijau jalan, Lapangan, RTH 
Pabrik DRP, dan RTH Kantor HSE. Enam lokasi tersebut dipilih karena lokasi tersebut sering dikunjungi karyawan pada saat sebelum masuk kerja, saat waktu istirahat, ataupun pada saat setelah waktu bekerja selesai (Gambar 4). Pengambilan data suhu ini dilakukan pada tiga jenis waktu yang berbeda menyesuaikan waktu saat karyawan sering berada di RTH tersebut yaitu pagi hari pukul 06.00-08.00, siang hari pukul 12.00-14.00, dan sore hari pukul 16.00-18.00. Pengambilan data suhu dilakukan saat kondisi hari cerah dengan jumlah 3 kali ulangan yaitu hari yang berbeda pada semua lokasi pengukuran.

Selain itu untuk mengetahui pengaruh vegetasi terhadap kenyamanan, pengambilan suhu dilakukan pada tiga kondisi yang berbeda yaitu dengan kondisi berada di bawah naungan pohon, dan perkerasan di luar RTH. Vegetasi yang dipilih adalah vegetasi yang mewakili populasi pada tapak dan lokasinya dapat dijangkau oleh karyawan (Tabel 5). Sedangkan perkerasan yang dipilih yaitu perkerasan di luar RTH yang tidak dinaungi oleh tajuk pohon.

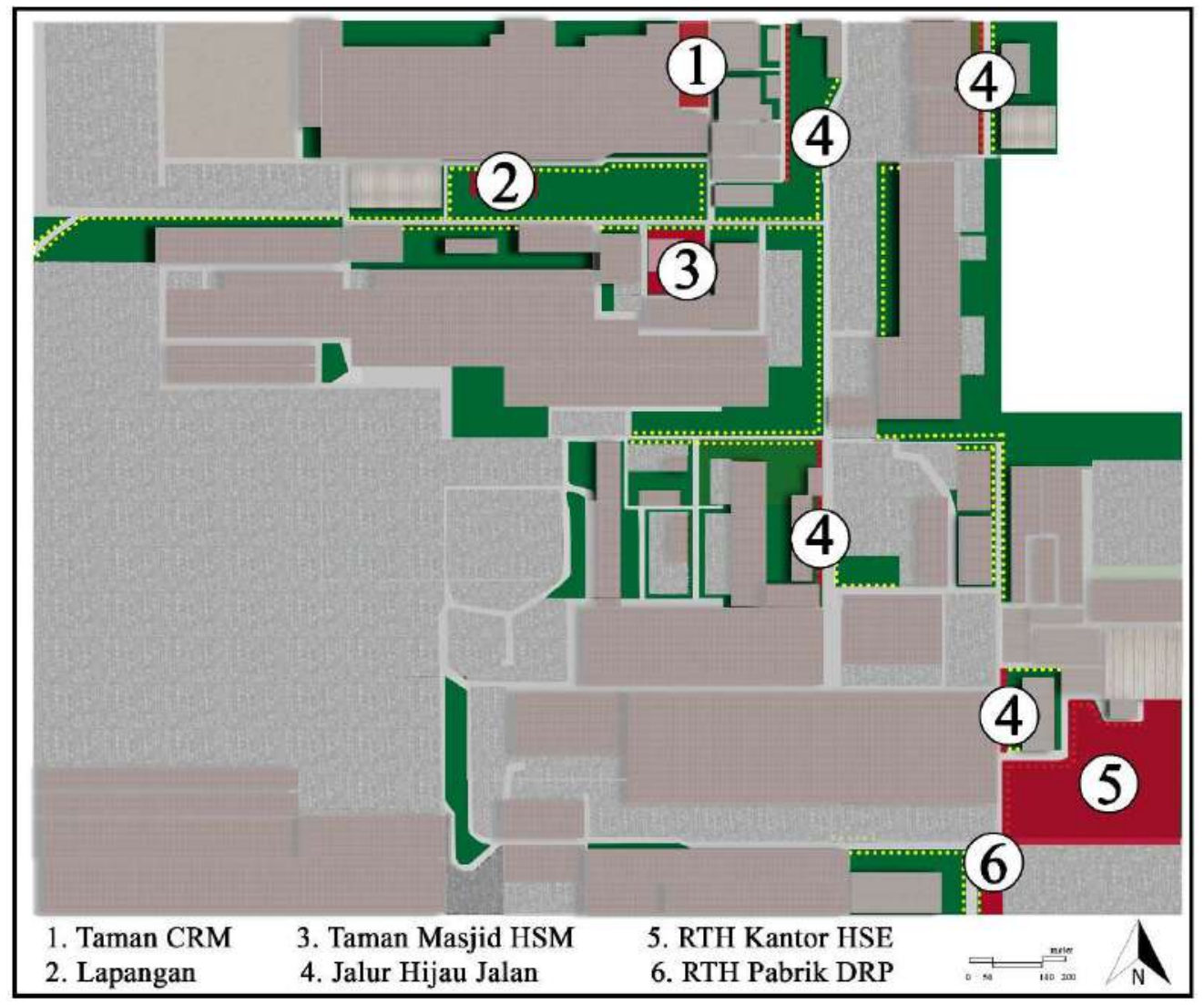

Gambar 4 Lokasi Pengukuran Suhu dan Kelembaban

Tabel 5 Jenis Vegetasi dalam Pengukuran Suhu dan Kelembaban

\begin{tabular}{|c|c|c|}
\hline No. & Lokasi Pengukuran & Di Bawah Naungan Vegetasi \\
\hline 1. & Taman CRM & $\begin{array}{ll}\text { - } & \text { Biola cantik (Ficus lyrata) } \\
\text { - } & \text { Mangga (Mangifera indica) }\end{array}$ \\
\hline
\end{tabular}


Tabel 5 (lanjutan) Jenis Vegetasi dalam Pengukuran Suhu dan Kelembaban

\begin{tabular}{|c|c|c|}
\hline 2. & Taman Masjid HSM & $\begin{array}{l}\text { - Mangga (Mangifera indica) } \\
\text { - } \text { Mahoni (Swietenia mahagoni) }\end{array}$ \\
\hline 3. & Lapangan & $\begin{array}{l}\text { - } \quad \text { Mangga (Mangifera indica) } \\
\text { - } \quad \text { Mahoni (Swietenia mahagoni) } \\
\text { - } \quad \text { Ki Hujan (Samanea saman) }\end{array}$ \\
\hline 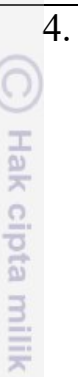 & Jalur Hijau Jalan & $\begin{array}{l}\text { - Palem Raja (Roystonea regia) di sebelah } \\
\text { barat Pabrik CRM } \\
\text { - Ki Hujan (Samanea saman) di sebelah barat } \\
\text { Pabrik WRM } \\
\text { - Glodogan Tiang (Polyathia longifolia) di } \\
\text { antara Pabrik SSP dan BSP } \\
\text { - } \text { Ki Hujan (Samanea saman) di antara Kantor } \\
\text { HSE dan Pabrik DRP }\end{array}$ \\
\hline & RTH Pabrik DRP & $\begin{array}{l}\text { - Akasia (Acacia longifolia) } \\
\text { - } \quad \text { Bambu kuning (Bambusa vulgaris) }\end{array}$ \\
\hline 6. & RTH Kantor HSE & $\begin{array}{ll}\text { - } & \text { Tanjung (Mimusops elengi) } \\
\text { - } & \text { Mahoni daun lebar (Swietenia macrophylla) } \\
\text { - } & \text { Ki Hujan (Samanea saman) }\end{array}$ \\
\hline
\end{tabular}

Dengan data suhu dan kelembaban yang sudah lengkap selanjutnya dicari rata-rata hasil pengukuran di setiap titik pengamatan. Data tersebut dibuat dalam bentuk tabulasi sehingga akan diperoleh rata-rata hasil pengukuran pada setiap waktu pengukuran dengan menggunakan rumus (Handoko 1995):

$$
\mathrm{T}=(\text { Tmaks }+\mathrm{Tmin}) / 2
$$

Keterangan :

Tmaks: suhu udara maksimum pada setiap titik pengukuran $\left({ }^{\circ} \mathrm{C}\right)$

Tmin: suhu udara minimum pada setiap titik pengukuran $\left({ }^{\circ} \mathrm{C}\right)$

Selanjutnya penghitungan suhu rata-rata pada hari tertentu berdasarkan suhu yang diamati yaitu suhu pagi hari sekitar pukul 06.00 hingga pukul 08.00, suhu siang hari sekitar pukul 12.00 hingga pukul 14.00, dan suhu sore hari sekitar pukul 16.00 hingga pukul 18.00. (Tpagi, Tsiang, Tsore). Rumus yang digunakan adalah

$$
\mathrm{T}=(2 \mathrm{Tpagi}+\mathrm{T} \text { siang }+\mathrm{T} \text { sore }) / 4
$$

Kelembaban rata-rata pada hari tertenstu dapat diketahui dengan menjumlah nilai kelembaban pada titik pengamatan pada setiap lokasi pengukuran, kemudian dibagi dengan banyaknya titik pengamatan dengan rumus:

$$
\mathrm{RH}=\mathrm{RH} \text { pagi }+\mathrm{RH} \text { siang }+\mathrm{RH} \text { sore } / 3
$$


Hubungan evaluasi kenyamanan termal menggunakan perhitungan THI (Temperature Humidity Index). Nilai THI dapat ditentukan dari nilai suhu udara dan kelembaban relatif (RH) dengan persamaan Mc Gregor dan Nieuwolt (1975):

$$
T H I=0,8 \times T+\left(\frac{R H \times T}{500}\right)
$$

Keterangan:

$\mathrm{THI}=$ Thermal Humidity Index, $\mathrm{T}=$ Suhu udara $\left({ }^{\circ} \mathrm{C}\right), \mathrm{RH}=$ Kelembaban Relatif $(\%)$

3) Analisis Persepsi dan Preferensi Karyawan dan Masyarakat

Analisis persepsi dan peferensi karyawan dan masyarakat adalah analisis berdasarkan hasil wawancara dan sebaran kuesioner. Karyawan yang akan dijadikan responden yaitu karyawan yang bekerja di kawasan industri PT Krakatau Steel, sedangkan masyarakat yang akan dijadikan responden yakni masyarakat yang tinggal di permukiman yang berdekatan dengan kawasan industri. Analisis ini untuk mengetahui persepsi karyawan terhadap kawasan industri, RTH di kawasan industri, kecukupan RTH, serta tingkat kenyamanan karyawan pada saat berada di RTH.

Penyebaran kuesioner diberikan pada 30 responden karyawan, selain itu dilakukan wawancara dilakukan terhadap 30 responden masyarakat. Wawancara dilakukan terhadap masyarakat umum di kecamatan Citangkil. Hasil wawancara dan sebaran kuesioner tersebut digunakan untuk mengetahui persepsi dan preferensi karyawan dan masyarakat terhadap kondisi kawasan industri dan RTH di dalamnya. Berikut merupakan peta lokasi permukiman masyarakat di sekitar kawasan industri PT Krakatau Steel (Gambar 5).

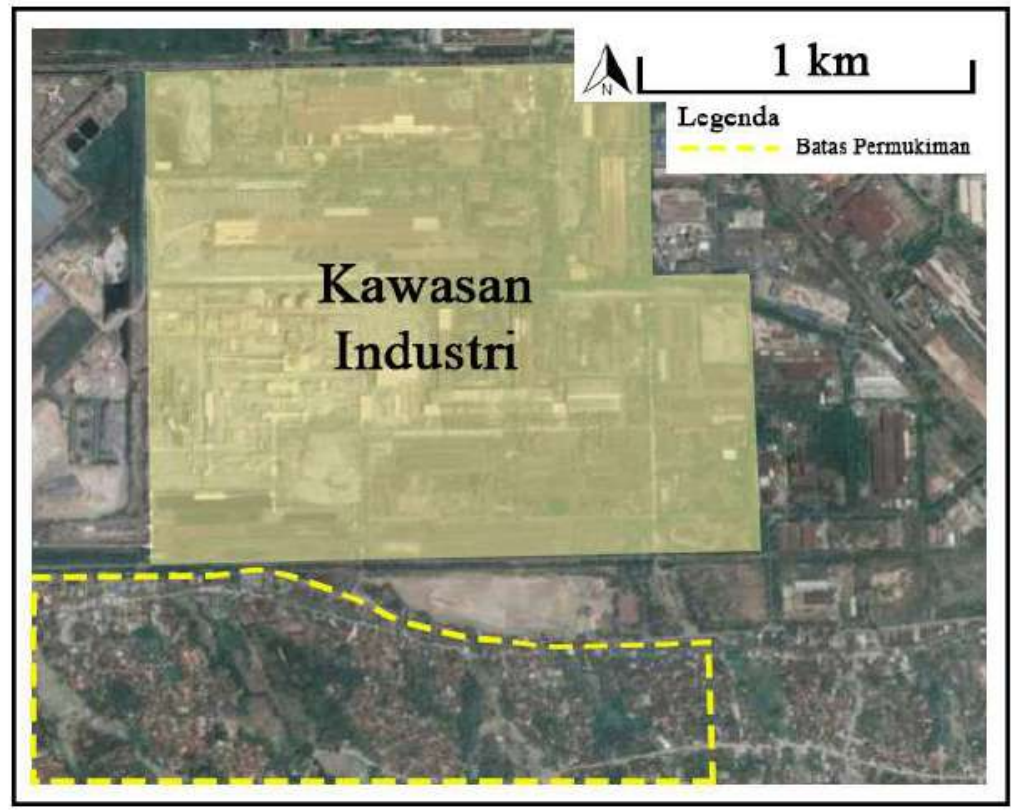

Gambar 5 Lokasi Permukiman Masyarakat 
4) Analisis SWOT

Analisis ini didasarkan pada logika yang dapat memaksimalkan kekuatan (strengths) dan peluang (opportunies), namun secara bersamaan meminimalkan kelemahan (weaknesses) dan ancaman (threaths). Analisis SWOT merupakan proses membandingkan antara faktor internal dan faktor eksternal. Faktor internal merupakan faktor yang ada di dalam kawasan industri baik berupa kekuatan (strengths) atau kelemahan (weaknesses). Sedangkan faktor eksternal merupakan faktor dari luar yang berpengaruh pada area industri baik berupa peluang (oppoortunies) maupun ancaman (threaths). Untuk melakukan analisis SWOT, langkah pertama yang dilakukan adalah menentukan faktor internal dan eksternal. Faktor ini diketahui dengan cara melakukan wawancara kepada narasumber. Narasumber yang diwawancarai oleh berjumlah 4 orang, yaitu Kepala Divisi Pengelola RTH, Ketua sub-divisi pembibitan, Ketua sub-divisi pemeliharaan RTH, dan Karyawan.

Analisis ini dimulai dengan mengidentifikasi faktor-faktor tersebut selanjutnya untuk dinilai berdasarkan tingkat kepentingannya atau besarnya pengaruh pada kawasan industri. Dari penilaian tersebut selanjutnya ditentukan strategi atau alternatif yang tepat untuk area industri sehingga industri tetap berkembang dengan baik dan lingkungan tetap terjaga. Berikut penjabaran mengenai tahapan analisis SWOT:

1. Identifikasi faktor internal-eksternal Pada tahap ini merupakan tahap pengumpulan semua data maupun informasi serta tahap pengklasifikasian praanalisis. Pada tahap ini data atau informasi yang didapatkan dibedakan menjadi dua yaitu data internal dan data eksternal. Data internal merupakan semua data yang berasal dari dalam (IFAS atau internal factor strategy) sedangkan data eksternal adalah semua data dari luar yang cukup berpengaruh atau berkaitan (EFAS atau eksternal factor strategy).

2. Penilaian faktor internal-eksternal Setelah data dikumpulkan dan diklasifikasikan berdasarkan tipenya masing-masing, selanjutnya dilakukan tahap penilaian. Tahap penilaian ini diarahkan untuk penentuan strategi melalui proses yaitu menyusun faktor-faktor IFAS atau EFAS yang telah diidentifikasi kemudian memberi bobot masing-masing faktor tersebut dengan nilai 1,00 (sangat penting) sampai dengan 0.00 (kurang penting).

Selanjutnya untuk menentukan nilai pembobotan semua faktor-faktor yang diidentifikasi diberi nilai berdasarkan pengaruhnya (Tabel 6 dan 7). Penentuan nilai setiap faktor menggunakan skala 1, 2, 3, dan 4 (David 2008), dengan ketentuan sebagai berikut:

a. nilai 1, jika faktor horizontal kurang penting dibandingkan faktor vertikal

b. nilai 2. Jika faktor horizontal sama pentingnya dengan faktor vertikal

c. nilai 3, jika faktor horizontal lebih penting dibandingkan faktor vertikal

d. nilai 4, jika faktor horizontal sangat penting dibandingkan faktor vertikal 
Tabel 6 Formulasi Pembobotan Faktor Internal

\begin{tabular}{|c|c|c|c|c|c|c|c|c|}
\hline Faktor y & Faktor $\mathrm{x}$ & S1 & S2 & W1 & W2 & W3 & Total & Bobot \\
\hline & $\mathrm{S} 1$ & & & & & & $\mathrm{X} 1$ & \\
\hline & S2 & & & & & & $\mathrm{X} 2$ & \\
\hline & W1 & & & & & & $\mathrm{X} 4$ & \\
\hline & W2 & & & & & & X5 & \\
\hline & W3 & & & & & & X6 & \\
\hline & & rotal & & & & & $\sum X n$ & \\
\hline
\end{tabular}

Sumber: Aniqa (2011)

Tabel 7 Formulasi Pembobotan Faktor Eksternal

\begin{tabular}{|c|c|c|c|c|c|c|}
\hline Faktor y & $\mathrm{O} 1$ & $\mathrm{O} 2$ & $\mathrm{~T} 1$ & T2 & Total & Bobot \\
\hline $\mathrm{O} 1$ & & & & & $\mathrm{Xl}$ & \\
\hline $\mathrm{O} 2$ & & & & & $\mathrm{X} 2$ & \\
\hline $\mathrm{Tl}$ & & & & & $\mathrm{X} 3$ & \\
\hline T2 & & & & & $\mathrm{X} 4$ & \\
\hline
\end{tabular}

Sumber: Aniqa (2011)

Bobot akhir setiap faktor diperoleh dengan menentukan nilai setiap faktor terhadap jumlah nilai keseluruhan variabel dengan menggunakan rumus (Kinnear \& Taylor 1991):

$$
a_{i}=\frac{x_{i}}{\sum x_{n}}
$$

Keterangan :

ai : nilai bobot faktor ke-n $\mathrm{x}$

$\mathrm{n}$ : total nilai keseluruhan faktor

i : variable $1,2,3, \ldots, n$.

Setelah memberi bobot pada masing-masing faktor dilakukan tahap selanjutnya yaitu pemberian rating. Perhitungan bobot dan penentuan rating (perangkingan) selanjutnya disajikan dalam tabel untuk menyajikan skor akhir (Tabel 8 dan 9).

Tabel 8 Formulasi Penilaian Faktor Internal

\begin{tabular}{llll}
\hline Faktor internal & Bobot & Rating & Skor \\
\hline Kekuatan & & & \\
\hline & & & \\
\hline Kelemahan & & \\
\hline Total & & \\
\hline
\end{tabular}

Sumber: Rangkuti (1997) 
Tabel 9 Formulasi Penilaian Faktor Eksternal

\begin{tabular}{lccc}
\hline Faktor eksternal & Bobot & Rating & Skor \\
\hline Peluang & & & \\
\hline & & \\
\hline Ancaman & & \\
\hline & & \\
\hline Total & & \\
\hline
\end{tabular}

Sumber: Rangkuti (1997)

Pemberian rangking pada masing-masing faktor berdasarkan tingkat kepentingannya atau besar pengaruhnya dengan angka 4 (sangat penting), 3 (penting), 2 (cukup penting), dan 1 (kurang penting). Kemudian bobot dan rating dikalikan untuk memperoleh skor pembobotan akhir. Hasil akhir ini berada pada kisaran 4 sampai dengan 1 yang artinya sesuai dengan tingkat kepentingannya 4 (sangat penting) dan 1 (kurang penting). Setelah penilaian ini, ditentukan strategi selanjutnya sesuai dengan penilaian tersebut. Sebelumnya, untuk mempermudah penyusunan strategi dibuat matriks internal-eksternal berdasarkan hasil skoring yang telah didapatkan (Gambar 6).

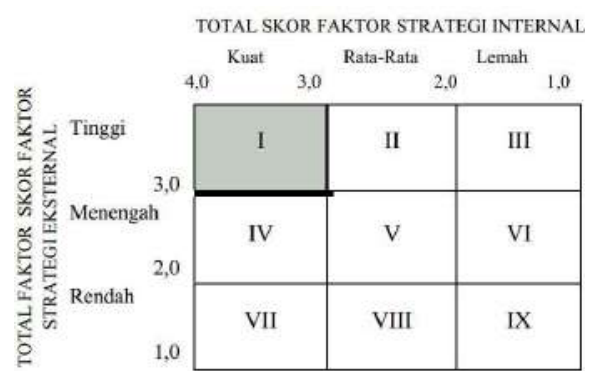

Gambar 6 Matriks Internal-Eksternal

Berdasarkan penilaian sebelumnya selanjutnya disusun strategi atau alternatif sesuai dengan kondisi yang ada. Alat yang digunakan untuk menyusun faktor-faktor yang telah diidentifikasi sebelumnya adalah matriks SWOT (Rangkuti 1997). Pada matrikss ini faktor satu dihubungkan dengan faktor yang lain untuk menentukan alternatif pada tiap-tiap hubungan faktor. Penyusunan matrik ini minimal akan menghasilkan 4 alternatif (Tabel 10).

- Strategi SO

Strategi ini dibuat dengan memanfaatkan seluruh kekuatan untuk memanfaatkan peluang sebesar-besarnya.

- Strategi ST

Strategi ini menggunakan kekuatan yang dimiliki untuk mengatasi ancaman.

- Strategi WO

Strategi ini diterapkan berdasarkan pemanfaatan peluang yang ada dengan cara meminimalkan kelemahan yang ada.

- Strategi WT

Strategi ini didasarkan ppada kegiatan yang bersifat defensif dan berusaha meminimalkan kelemahan yang ada serta menghindari ancaman. 
Tabel 10 Matriks SWOT

\begin{tabular}{|l|l|l|}
\hline \multirow{2}{*}{ Eksternal } & \multicolumn{1}{|c|}{ Strenghts (S) } & \multicolumn{1}{c|}{ Weakness (W) } \\
\cline { 2 - 3 } & $\begin{array}{l}\text { Tentukan faktor-faktor } \\
\text { kekuatan internal }\end{array}$ & $\begin{array}{l}\text { Tentukan faktor-faktor } \\
\text { kelemahan internal }\end{array}$ \\
\hline \multicolumn{1}{|c|}{ Opportunities (O) } & \multicolumn{1}{|c|}{ Strategi SO } & \multicolumn{1}{c|}{ Strategi WO } \\
\hline $\begin{array}{l}\text { Tentukan faktor-faktor } \\
\text { peluang eksternal }\end{array}$ & $\begin{array}{l}\text { Strategi yang menggunakan } \\
\text { kekuatan untuk memanfaatkan } \\
\text { peluang }\end{array}$ & $\begin{array}{l}\text { Strategi yang meminimalkan } \\
\text { kelemahan untuk } \\
\text { memanfaatkan peluang }\end{array}$ \\
\hline \multicolumn{1}{|c|}{ Threats (T) } & \multicolumn{1}{|c|}{ Strategi ST } & \multicolumn{1}{c|}{ Strategi WT } \\
\hline $\begin{array}{l}\text { Tentukan faktor-faktor } \\
\text { ancaman eksternal }\end{array}$ & $\begin{array}{l}\text { Strategi yang menggunakan } \\
\text { kekuatan untuk mengatasi } \\
\text { ancaman }\end{array}$ & $\begin{array}{l}\text { Strategi yang meminimalkan } \\
\text { kelemahan dan menghindari } \\
\text { ancaman }\end{array}$ \\
\hline
\end{tabular}

\section{4) Penyusunan rekomendasi}

Hasil analisis selanjutnya dievaluasi kemudian disusun rekomendasi untuk pengembangan RTH di Kawasan Industri PT Krakatau Steel. Penyusunan rekomendasi adalah tahap akhir dari penelitian ini berdasarkan hasil analisis dan sintesis. Rekomendasi ini menyesuaikan pada hasil analisis dan sintesis dimana jika hasilnya menunjukkan bahwa kondisi ruang terbuka hijau di kawasan industri tersebut tidak sesuai maka diberikan usulan atau rekomendasi untuk melakukan perbaikan. Sebaliknya, jika sesuai maka diberikan usulan untuk mempertahankan serta tetap meningkatkan kualitas RTH yang ada untuk menjadi lebih baik. Salah satunya yaitu dsengan memberikan rekomendasi penataan ruang terbuka hijau yang disajikan dalam bentuk deskripsi maupun gambar.

\section{KONDISI UMUM}

\section{Kondisi Fisik Kota Cilegon}

Kota Cilegon dengan luas 17.550 Ha merupakan bagian dari Propinsi Banten dan berada di bagian ujung barat dari Pulau Jawa, terbagi kedalam 8 kecamatan dan 41 kelurahan (Gambar 6). Secara geografis, Kota Cilegon terletak

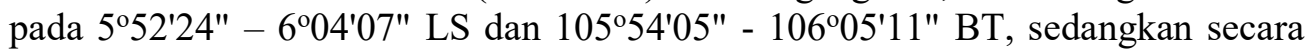
administratif Kota Cilegon memiliki batas - batas sebagai berikut:

- Sebelah utara berbatasan dengan Kecamatan Bojonegara (Kabupaten

Serang),

- Sebelah barat berbatasan dengan Selat Sunda,

- Sebelah selatan berbatasan dengan Kecamatan Anyar dan Kecamatan

Mancak (Kabupaten Serang), dan

- Sebelah timur berbatasan dengan Kecamatan Kramatwatu (Kabupaten Serang)

Secara umum keadaan morfologi Kota Cilegon terbagi atas tiga kelompok besar yaitu morfologi mendatar, morfologi perbukitan landai-sedang dan morfologi perbukitan terjal. Fisik daerahnya sangat bervariasi ditinjau dari ketinggian maupun lereng. Morfologi dataran pada umumnya terdapat pada wilayah tengah dan timur kota dan dan wilayah pantai barat kota dengan 17 kemiringan kecil berkisar 0-2\% 
dan 2-7 \%. Morfologi landai sedang terdapat di wilayah tengah kota. Morfologi perbukitan terjal terdapat di sebagian wilayah utara dengan kemiringan lebih dari $30 \%$ dan sebagian kecil wilayah selatan kota. Topografi Kota Cilegon sangat bervariasi namun relatif landai dan didominasi tanah dataran sekitar $76.66 \%$. Bagian Utara dan Selatan kota, tanah cenderung berbukit (15.85\%) dan 35.1 ha $(0.20 \%)$ merupakan tanah pegunungan dan pesisir pantai $(7.26 \%)$ dari luas kota (BPS Kota Cilegon 2018). Berikut adalah peta Kota Cilegon (Gambar 7)

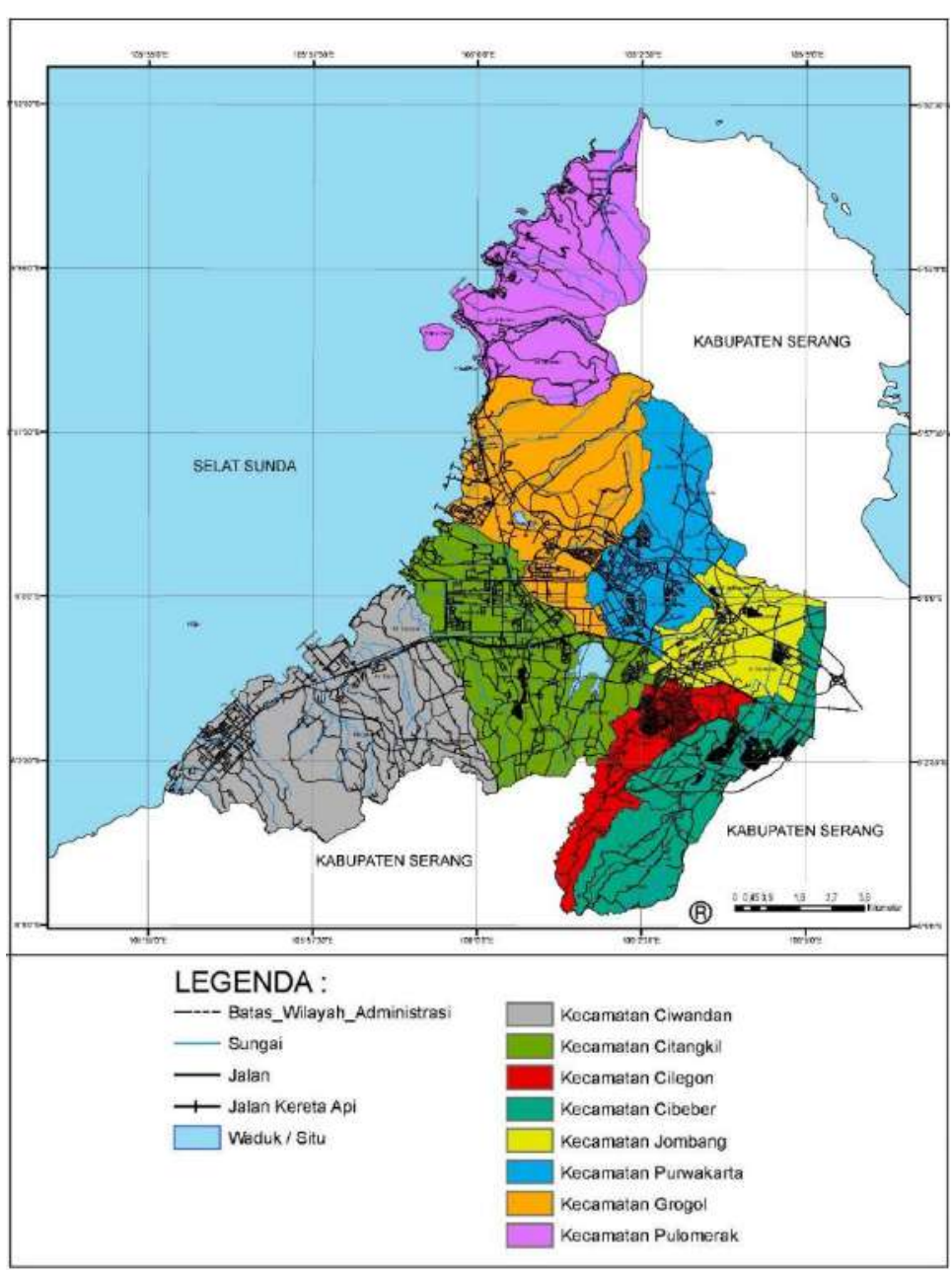

Gambar 7 Peta Kota Cilegon Sumber: Bappeda Kota Cilegon (2018)

Kondisi fungsi-fungsi ruang kawasan kota Cilegon adalah sebagai berikut:

a. Kawasan perumahan terkonsentrasi pada pusat kota, atau lebih tepatnya berada di Kecamatan Cilegon, Kecamatan Jombang, Kecamatan Citangkil dan Kecamatan Purwakarta.

b. Kawasan pertanian dan tegalan terdistribusi di daerah peralihan kota atau pinggiran pusat kota. 
c. Kawasan Industri terkonsentrasi pada bagian timur kota. Jalur hijau, kawasan lindung/waduk terkonsentrasi pada bagian utara kota.

d.Kawasan pemerintahan dan perkantoran serta pelayanan umum, terkonsentrasi pada pusat kota.

e. Kawasan olah raga/open space/ taman dan kawasan wisata terkonsentrasi pada kawasan terbuka dan sepanjang pantai.

Kawasan industri di Kota Cilegon terintegrasi dalam Kawasan Industri Krakatau. Semua pabrik dan kawasan industri yang berada di Kota Cilegon berada di dalam kawasan tersebut dan tidak boleh berada di luar kawasan. Luas Kawasan Industri Krakatau yaitu 2771,5 Ha atau 15,9\% dari total penggunaan wilayah Kota Cilegon. Pengelola dalam Kawasan Industri Krakatau adalah PT Krakatau Industrial Estate Cilegon (PT KIEC). Dalam hal ini, PT KIEC menyediakan lahan industri bagi para investor. Saat ini hampir semua lahan PT KIEC habis karena banyaknya investor yang membangun kawasan industri baru. Untuk meminimalisir dampak dari pembangunan kawasan industri baru, PT KIEC mewajibkan seluruh perusahaan menambah RTH di kawasan industrinya. Hingga saat ini, RTH di dalam Kawasan Industri Krakatau luasnya mencapai 15\% dari keseluruhan RTH di Kota Cilegon.

\section{Sejarah PT Krakatau Steel}

PT Krakatau Steel yang berlokasi di Cilegon merupakan industri pengolahan baja terbesar di Indonesia. Presiden Soekarno pada tahun 1960 merencanakan proyek Besi Baja Trikora untuk meletakkan dasar industri nasional yang tangguh. Setelah studi kelayakan selesai disusun, Cilegon dipilih sebagai tempat proyek tersebut yaitu pengolahan dan produksi hasil olahan bijih besi karena terdapat lahan luas yang tidak mengalihfungsikan lahan pertanian, terdapat sumber air yang melimpah, serta aksesnya yang terjangkau dari berbagai pulau karena dekat dengan pelabuhan Merak. Kemudian pada 31 Agustus 1970, berdirilah PT. Krakatau Steel yang memanfaatkan kembali peralatan-peralatan dari proyek itu yang berbentuk pabrik kawat baja, pabrik baja tulangan dan pabrik baja profil. Pada 1977, Presiden Soehartoo meresmikan mulai beroperasinya PT Krakatau Steel.

Pada tahun 1979, diresmikan penggunaan fasilitas-fasilitas Pabrik Besi Spons, Pabrik Batang Kawat Baja, serta fasilitas infrastrukur berupa pusat Pembangkit Listrik Tenaga Uap 400 MW, Pusat Penjernihan Air, Pelabuhan Cigading, serta Sistem Telekomunikasi. Pada tahun 1983 diresmikan beroperasinya Pabrik Slab Baja dan Pabrik Baja Lembaran Panas. Pada tahun 1991 Pabrik Baja Lembaran Dingin yang merupakan pabrik baja perusahaan patungan yang berada di kawasan industri Cilegon bergabung menjadi unit produksi PT Krakatau Steel, melengkapi pabrik-pabrik baja lain yang telah ada.

PT Krakatau Steel pada tahun 2003 telah memperoleh Sertifikasi ISO 9001. SGS International juga telah memberikan Sertifikasi ISO 14001 terhadap PT Krakatau Steel sejak 1997 atas komitmen Perseroan terhadap kesadaran lingkungan dan keselamatan kerja. Pada 10 November 2010, di tengah kondisi pasar yang masih bergejolak, PT Krakatau Steel berhasil menjadi perusahaan terbuka dengan melaksanakan penawaran umum perdana (IPO) dan mencatatkan sahamnya di Bursa Efek Indonesia. Hingga tahun 2017, PT Krakatau Steel telah memasarkan produknya untuk konsumen domestik dan luar negeri. 


\section{Kondisi Fisik Lokasi Penelitian}

\section{Lokasi}

Lokasi kawasan industri PT Krakatau Steel berada di Jalan Industri 5, Kota Cilegon, Provinsi Banten. Kawasan industri PT Krakatau Steel merupakan bagian dari Kawasan Industri Krakatau (Krakatau Industrial Estate). Luas keseluruhan PT Krakatau Steel mencapai 285 ha. Bagian utara, timur, dan barat berbatasan dengan Kawasan Industri Krakatau. Bagian selatan berbatasan langsung dengan permukiman penduduk.

Kawasan industri Krakatau Steel berada di daerah pesisir dekat dengan Selat Sunda (Gambar 8). Lokasi yang strategis tersebut mempermudah dalam pengiriman barang antar pulau serta mancanegara melalui pelabuhan Cigading. Keberadaan laut yang sangat dekat membuat kawasan ini mudah mendapatkan air untuk kegiatan industrinya. Lokasi kawasan industri juga dilalui jalur kereta api yang dapat memudahkan pengiriman barang melalui jalur darat.

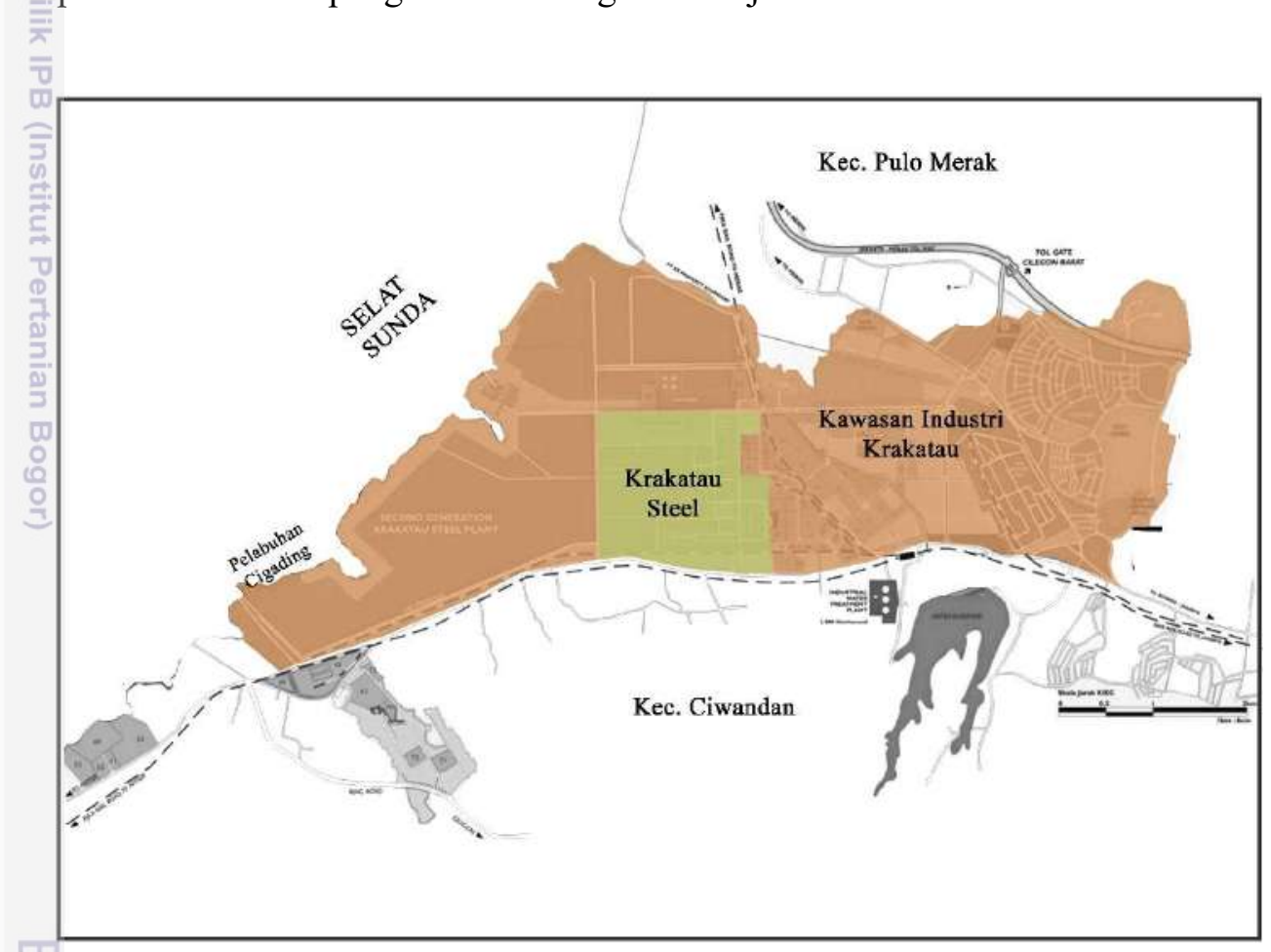

Gambar 8 Lokasi PT Krakatau Steel

\section{Iklim}

Berdasarkan data yang diperoleh dari Badan Meteorologi Klimatologi dan Geofisika, Stasiun Meteorologi Kelas I Serang pada tahun 2017, diketahui bahwa temperatur udara rata-rata bulanan pada tapak tidak mengalami fluktuasi secara signifikan, bahkan cenderung stabil, dengan temperatur rata-rata sekitar $26,9^{\circ} \mathrm{C}$ $28,1^{\circ} \mathrm{C}$, temperatur tertinggi sebesar $35,4^{\circ} \mathrm{C}$ dan temperatur terendah sebesar $21,3^{\circ} \mathrm{C}$. Kelembaban udara pada tapak cukup tinggi, yaitu antara $77-85 \%$. Lama penyinaran matahari sebesar 35-75\% dengan lama penyinaran terbesar pada bulan Juli. Arah 
angin rata-rata pada tapak umumnya berasal dari arah barat, dan utara dengan kecepatan angin rata-rata sebesar 1,1-2,4 knot (Gambar 9). Kecepatan angin terbesar sebesar 14 knot dengan arah angin dari utara. Curah hujan pada tahun 2017 rata-rata $150,3 \mathrm{~mm} /$ bulan dengan rata-rata hari hujan 16,8 hari dan curah hujan terbesar di bulan Januari serta curah hujan terkecil di bulan Agustus.

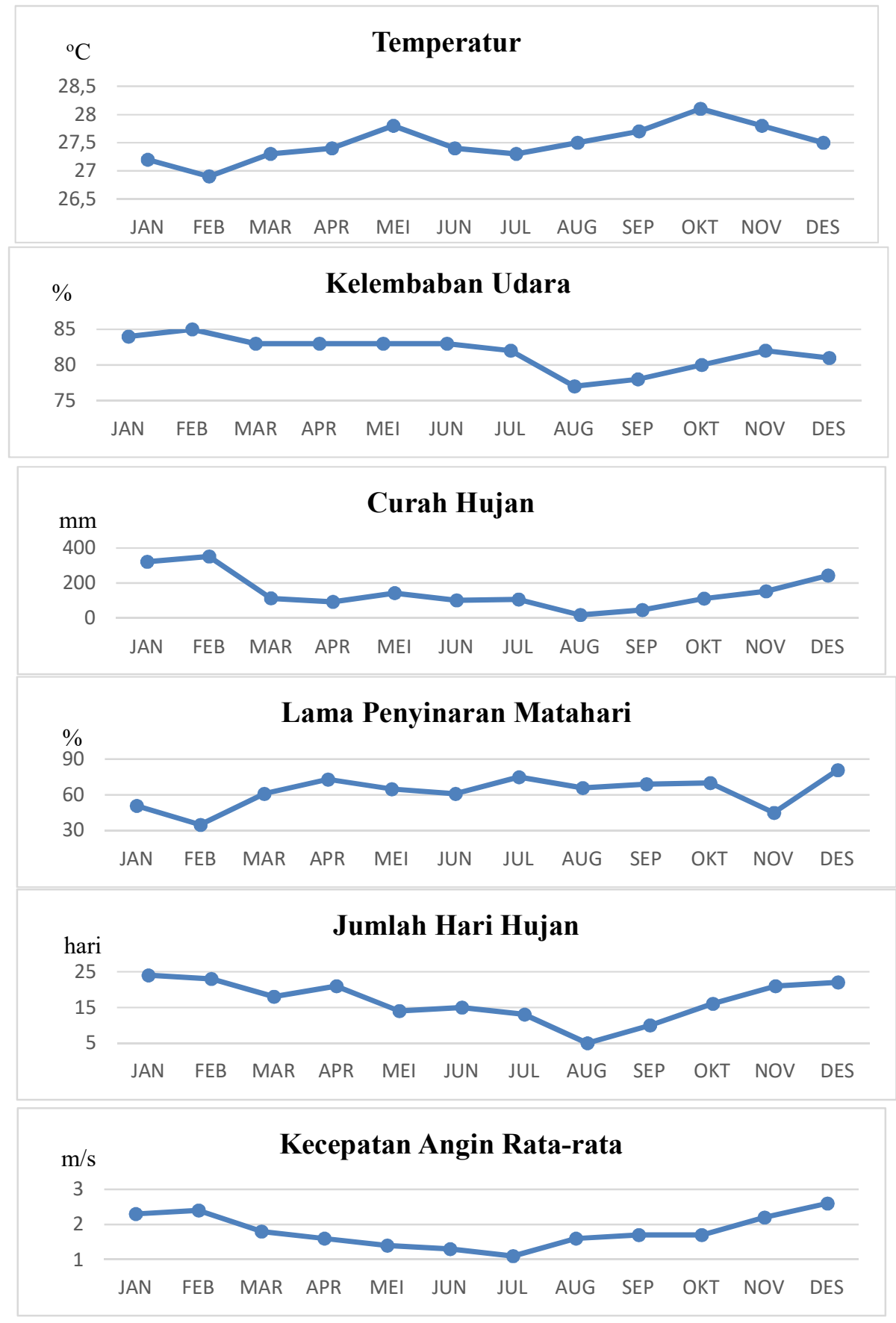

Gambar 9 Grafik Beberapa Unsur Iklim Bulanan

Sumber: Badan Meteorologi Klimatologi dan Geofisika, Stasiun Meteorologi Klas I Serang (2018) 


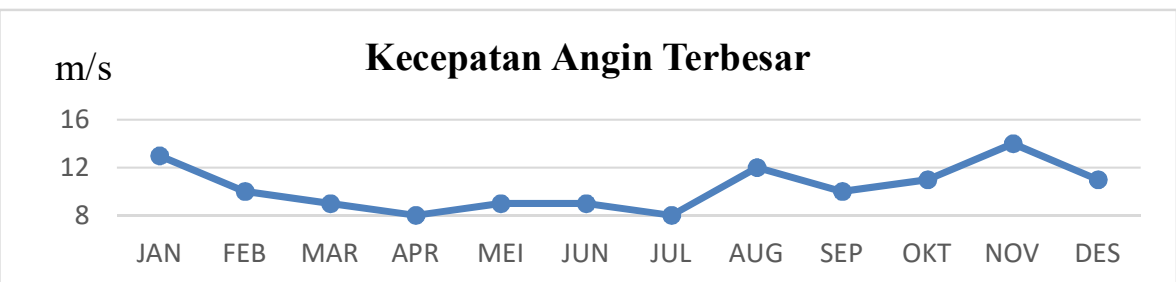

Gambar 9 (lanjutan) Grafik beberapa unsur iklim bulanan Sumber: Badan Meteorologi Klimatologi dan Geofisika, Stasiun Meteorologi Klas I Serang (2018)

Tanah

Berdasarkan peta Jenis tanah yang bersumber dari Badan Perencanaan Pembangunan Daerah (Bappeda) Kota Cilegon, jenis tanah di kawasan industri PT Krakatau Steel adalah Regosol dengan kedalaman efektif tanah $<90 \mathrm{~cm}$ dengan tekstur halus (Gambar 10). Umumnya makin halus tekstur tanah regosol maka tanah tersebut makin produktif. Tanah Regosol pada umumnya berasal dari abu vulkanik hasil erosi gunung berapi. Tanah ini pembentukan lapisannya kurang signifikan karena kondisi iklim kering. Selain Tanah Regosol, sebagian besar tanah yaitu jenis tanah alluvial dengan kedalaman efektif tanah $>90 \mathrm{~cm}$ dengan tekstur kasar. Sifat tanah berdasarkan hasil analisis PT KIEC (2010) dapat dilihat pada Tabel 11.

Tabel 11 Jenis dan Sifat Tanah di PT Krakatau Steel

\begin{tabular}{|c|c|c|}
\hline Jenis Tanah & Sifat Tanah & Analisis \\
\hline $\begin{array}{ll}\text { Regosol dan } \\
\text { Alluvial }\end{array}$ & $\begin{array}{l}\text { - Tekstur halus sampai kasar } \\
\text { (lempung liat berpasir-pasir } \\
\text { berlempung) } \\
\text { - Kemasaman (Netral sampai } \\
\text { sedikit basa (pH H} \mathrm{H}_{2} \mathrm{O} 6,92 \text { - } \\
7,92 \text { ) } \\
\text { - Zat organik : rendah (0,1 - 1,2 } \\
\text { \% ) } \\
\text { - Porositas dan permeabilitas : } \\
\text { sedang - cepat (7,8 cm / jam) } \\
\text { - KTK: rendah sampai sedang } \\
\text { 0,583 - 2,748 me/100gr } \\
\text { - KB : rendah - tinggi (30-84\%) }\end{array}$ & $\begin{array}{l}\text { - Tanah bertekstur kasar } \\
\text { memiliki aerasi dan } \\
\text { drainase yang baik } \\
\text { namun tidak mempunyai } \\
\text { kemampuan menjerap } \\
\text { hara dan air. Sedangkan } \\
\text { jika bertekstur halus } \\
\text { menahan air sehingga } \\
\text { menyebabkan } \\
\text { penggenangan } \\
\text { - Permeabilitas dan } \\
\text { porositas yang cepat akan } \\
\text { menyebabkan }\end{array}$ \\
\hline
\end{tabular}

Sumber : PT Krakatau Steel, dalam Jahara (2002) 


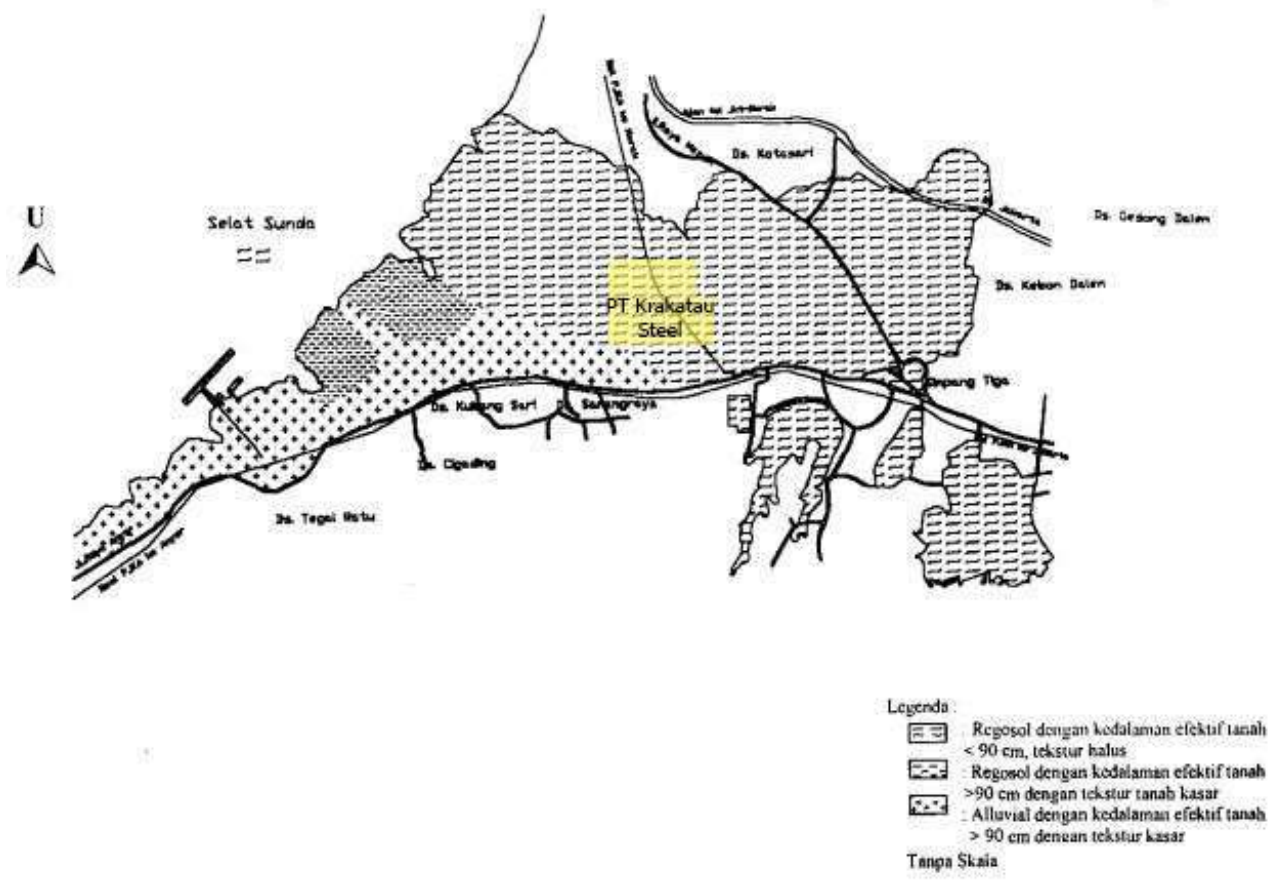

Gambar 10 Peta Tanah di Kawasan Industri Krakatau Sumber: PT Krakatau Steel, dalam Jahara (2002)

\section{Topografi}

Berdasarkan laporan AMDAL PT Krakatau Steel seluruh kawasan industri berada di ketinggian 1,5-3 meter di atas permukaan laut (dpl). Secara umum tapak penelitian memiliki topografi datar dengan kemiringan lahan sebesar 0-3\%. Topografi yang datar sesuai untuk lokasi kawasan industri karena dapat memudahkan pengangkutan barang menuju daerah lain. Tetapi topografi yang datar pada tapak menimbulkan kendala yang menimbulkan masalah drainase seperti terjadinya penggenangan saat terjadi hujan di area terbuka di pabrik.

\section{Hidrologi}

Air baku yang digunakan di kawasan industri merupakan air yang diambil sungai Cidanau. Air sungai tersebut berasal dari danau bernama Rawa Dano, yang di sekelilingnya terdapat hutan lindung yang dijaga oleh masyarakat. Air tersebut kemudian diolah di PT Krakatau Tirta Industri dan disalurkan ke PT Kratatau Steel. Air baku yang telah dipakai untuk kegiatan industri baja dan telah menjadi uap diolah kembali di Waste Water Treatment Plant (WTP).

Waste Water Treatment Plant yang berfungsi untuk menetralisir dan menghilangkan bahan pencemar sebelum dibuang ke saluran air. Oil Separator dipasang pada ujung saluran air sebelum keluar kesaluran umum berfungsi untuk memisahkan minyak yang terkandung dalam air limbah yang ikut terbuang ke saluran air. Sisa air yang tidak terpakai kemudian dibuang ke saluran pembuangan menuju ke laut. 


\section{Tata Guna Lahan}

PT Krakatau Steel memiliki luas keseluruhan 285 ha. Penggunaan lahan pada kawasan dibagi menjadi dua, yaitu area terbangun dan area terbuka. Area terbangun terdiri dari area plant (pabrik), kantor, kantin, gudang, masjid, dan penggunaan lainnya. Area terbuka terdiri dari area terbuka hijau yang ditanami pepohonan, taman, lapangan, area parkir, dan lahan terbuka untuk penyimpanan produk baja. Area terbuka didominasi oleh area terbuka hijau yang ditanami tanaman yang berada pada kawasan pabrik dengan luas 34 ha. Area terbangun memiliki proporsi lebih besar dibandingkan ruang terbuka hijau, dengan luas 218 ha. Perbandingan area terbuka dan terbangun adalah 1:6 dengan area terbuka didominasi oleh area pepohonan.

\section{Pembagian Kawasan Industri}

PT Krakatau Steel merupakan industri yang menghasilkan baja setengah jadi dengan berbagai macam ukuran dengan proses pengolahan yang berbeda. Terdapat enam kawasan pabrik yang terintegrasi menjadi satu kesatuan dalam menghasilkan produk (Gambar 10). Adapun keenam pabrik di PT Krakatau Steel (PT KS) adalah sebagai berikut:

1. Pabrik Besi Spons (Direct Reduction Plant / DRP)

Direct Reduction Plant merupakan pabrik besi spons yang mereduksi langsung bahan baku bijih besi (pellet) sebesar biji kelereng menjadi bahan baku untuk membuat baja bagi pabrik lainnya. Pabrik ini mulai beroperasi tahun 1978 dan terdiri dari empat modul dengan kapasitas terpasang masing-masing 500.000 ton per tahun. Aktivitas pabrik ini sangat intensif beroperasi pada bulan tertentu saja karena pabrik ini menghasilkan barang baku untuk semua kawasan pabrik di PT Krakatau Steel.

2. Pabrik Baja Billet (Billet Steel Plant / BSP)

Billet Steel Plant menghasilkan baja batangan. Pabrik ini memiliki empat dapur yang masing-masing berkapasitas 65 ton dan mesin Continous Casting. Kapasitas yang terpasang mencapai 500.000 ton pertahun. Aktivitas pabrik ini intensif setiap harinya.

3. Pabrik Besi Slab (Slab Steel Plant / SSP)

Slab Steel Plant mulai berproduksi pada tahun 1983. Pabrik ini menggunakan besi spons sebagai bahan baku untuk dijadikan slab (lempengan). Pabrik baja slab dilengkapi dengan enam buah electric furnace. Kapasitas produksi slab yang terpasang mencapai 1 juta ton pertahun.

4. Pabrik Batangan Kawat (Wire Rod Plant / WRP)

Pabrik Baja Billet menghasilkan baja batangan kawat. Pabrik ini memiliki empat dapur yang berkapasitas 65 ton dan kapasitas yang terpasang mencapai 500.000 ton. Aktivitas pabrik ini sangat intensif dan menghasilkan debu yang cukup banyak.

5. Pabrik Plat Baja Canai Panas (Hot Strip Mill / HSM)

Pabrik ini memproduksi baja lembaran dengan pengerolan panas, berkapasitas 2,5 juta ton pertahun dan bahan baku yang digunakan adalah slab baja dari Slab Steel Plant (SSP). Pabrik ini menghasilkan kebisingan dan tekanan panas 
yang tinggi di banding pabrik lainnya. Temperatur di dalam pabrik berkisar 600$1500^{\circ} \mathrm{C}$. Karyawan di pabrik ini wajib menggunakan peralatan keselamatan kerja seperti helm, kacamata, dan earplug.

6. Pabrik Plat Baja Canai Dingin (Cold Rolling Mill / CRM)

Bahan baju pabrik ini berasal dari Pabrik Plat Baja Canai Panas (HSM). Hasil produksi pabrik ini mencapai 850.000 ton pertahun. Dari baja lembaran tersebut dapat diolah menjadi kaleng kemasan makanan atau produk lainnya. Aktivitas pabrik ini cukup intensif dan menghasilkan tekanan panas tinggi, karyawan wajib menggunakan peralatan keselamatan kerja saat memasuki pabrik, seperti helm, kacamata, dan earplug.

Kawasan pabrik saat ini terdiri menjadi enam pabrik, tetapi terdapat satu pabrik yang sedang dalam pembangunan yaitu project blast furnace. Selain pabrik, di kawasan industri juga terdapat area lainnya, diantaranya

1. Area penerimaan dengan fasilitas yang ada pada area ini yaitu main sign PT $\mathrm{KS}$, tempat parkir motor dan mobil, pos jaga, serta portal yang berfungsi mengontrol kendaraan yang dapat keluar masuk kawasan.

2. Area perkantoran yang lokasinya tersebar dalam kawasan industri mulai dari kantor direktur, kantor logistik, laboratorium, Kantor Divisi General Affair, dan kantor Divisi K3LH / Human Service and Environment (HSE). Kantor direktur merupakan kantor yang digunakan oleh direktur-direktur PT KS, kantor logistik merupakan kantor bagi karyawan divisi logistik, laboratorium terdiri dari laboratorium kimia dan mekanik yang berfungsi untuk mengontrol kualitas baja dan meneliti kerusakan pada baja, kantor divisi general affair yaitu kantor bagi divisi yang berkonsentrasi dalam menyediakan barang dan jasa yang dibutuhkan untuk kegiatan operasional perusahaan serta pengelolaan $\mathrm{RTH}$, kantor divisi K3LH merupakan kantor yang terdiri dari laboratorium lingkungan untuk mengontrol kualitas udara, air, dan limbah yang terdapat di kawasan industri serta lingkungan sekitar di luar kawasan industri.

3. Area pelayanan yang penempatannya terpisah-pisah, tidak terpusat pada suatu area. Fasilitas pelayanan pada kawasan terdiri dari kantin, masjid, dan lapangan basket yang berada dekat gedung kantor.

Keenam kawasan pabrik di PT Krakatau Steel, Pabrik CRM, HSM, WRM, DRP, BSP, SSP, dan HSE masing-masing memiliki RTH yang tertata dengan baik. Basemap kawasan industri dapat dilihat pada Gambar 11. 


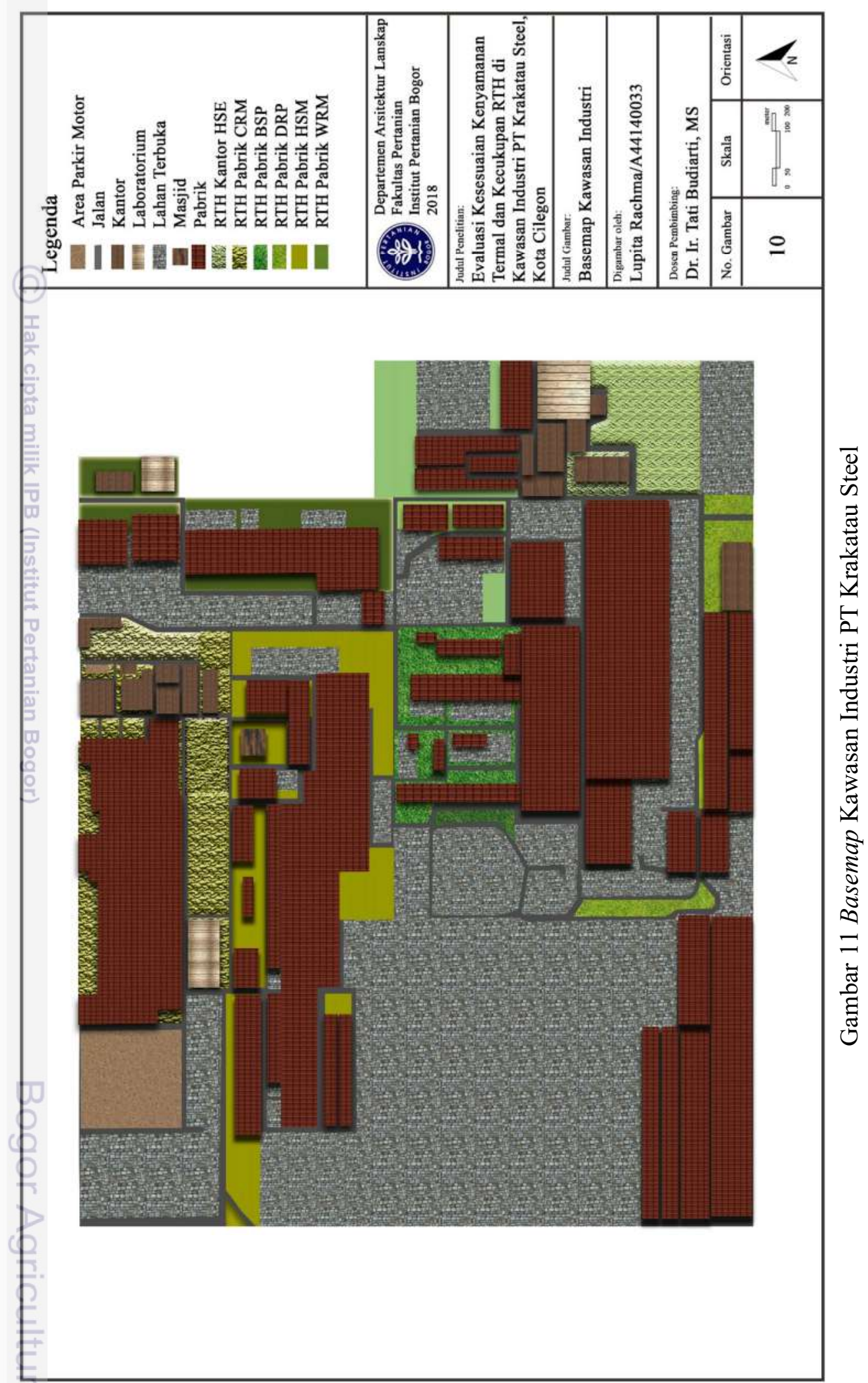




\section{Kualitas Udara}

Kualitas udara pabrik dipengaruhi oleh aktvitas pabrik serta asap kendaraan pengangkut barang. Aktivitas pabrik berupa proses pengolahan baja terpadu yang menghasilkan emisi udara. Emisi udara dikeluarkan melalui cerobong asap dari masing-masing pabrik, tetapi sebelum keluar melalui cerobong asap terdapat alat filter dusting yang berfungsi memfilter debu emisi sehingga konsentrasi zat berbahaya yang tersebar ke udara menjadi seminim mungkin.

Pengontrolan kualitas udara dilakukan oleh Divisi Health, Services, and Environment (HSE) atau K3LH setiap sebulan sekali. Pengontrolan ini dilakukan agar dapat mengingatkan setiap pabrik yang debu emisinya melebihi ambang batas atau baku mutu yang ditetapkan pemerintah. Berikut adalah hasil pengukuran konsentrasi emisi udara yang dilakukan di laboratorium lingkungan oleh bagian Divisi Health, Services, and Environment di PT KS pada Januari 2018 (Tabel 12)

Tabel 12 Konsentrasi Polusi Udara di Lingkungan Industri PT KS

\begin{tabular}{ccc}
\hline Parameter & Konsentrasi (mg/M3) & Baku Mutu (mg/M3) \\
\hline $\mathrm{SO}_{2}$ & $<50$ & 500 \\
\hline $\mathrm{NO}_{2}$ & 100 & 1000 \\
\hline $\mathrm{Debu}$ & $<50$ & 150 \\
\hline
\end{tabular}

Sumber: Divisi HSE/K3LH PT Krakatau Steel (2018)

Tabel tersebut menunjukkan emisi udara yang dihasilkan pada pabrik tidak melewati nilai ambang batas yang ditetapkan pemerintah. Kualitas udara di lingkungan pabrik masih tergolong aman bagi manusia, tetapi akan lebih baik jika emisi udara tersebut dapat dikurangi agar kualitas udara di lingkungan pabrik menjadi lebih baik. Berbagai upaya terus dilakukan setiap pabrik di PT KS agar dapat mengurangi emisi udara tersebut, seperti peningkatan teknologi untuk memfilter debu dan penanaman tanaman yang dapat menyaring debu.

\section{Limbah}

Limbah cair merupakan limbah berbentuk cairan yang merupakan sisa dari pengolahan baja terpadu di pabrik. Kandungan limbah cair yang dihasilkan PT KS yakni terdiri dari besi terlarut, mangan terlarut, tembaga, seng, krom, timbal, nikel, kobalt, cadmium, sianida, klorin bebas, nitrat, nitrit, sulfida, fenol, dan amonia. Seluruh kandungan limbah cair tersebut nilainya $<0,05$ masih di bawah baku mutu air. Namun, $\mathrm{pH}$ pada limbah cair pada kawasan tergolong tidak terlalu rentan yaitu sebesar 7-8 tetapi di khusus di pabrik CRM pHnya hampir mencapai 9 karena pengolahannya banyak menghasilkan senyawa basa. Kondisi $\mathrm{pH}$ air di kawasan industri PT KS masih belum melewati ambang batas, karena baku mutu pH yang ditetapkan sebesar 6-9. 


\section{HASIL DAN PEMBAHASAN}

\section{Analisis Kecukupan Ruang Terbuka Hijau}

Menurut analisis citra yang dilakukan oleh perusahaan tahun 2017, di dalam Kawasan Industri PT KS terdapat ruang terbuka hijau (RTH) dengan total luas 34 Ha dari total luas kawasan industri 285 Ha. Jika dilihat dari luasannya, kawasan industri sudah cukup baik karena walapun dengan kepadatan bangunan dan area terbangunnya saat ini, area industri sudah memiliki RTH seluas $12 \%$ dari total lahan dan sudah memenuhi kewajiban RTH minimum $10 \%$ dari total lahan. Hal ini sesuai dengan UU No. 26 Tahun 2007 dan Peraturan Menteri Perindustrian No.40 tahun 2016 yang mengharuskan bahwa RTH minimal kawasan industri yaitu 10\% dari luas area.

Seluruh ruang terbuka hijau dengan luas 34 ha tersebut dikelola oleh Divisi General Affair. Divisi tersebut salah satu tugas utamanya untuk mengontrol kondisi tanaman dan kerapihan RTH, serta melakukan pembibitan tanaman. Pembibitan tanaman tersebut berlokasi di pembibitan khusus di luar kawasan industri. Tanaman di pembibitan ini diperbanyak untuk kemudian ditanam di kawasan industri, yang terdiri dari jenis tanaman pohon dan tanaman hias. Jenis tanaman yang telah berhasil di semai sebanyak 47 jenis, dengan jenis yang paling banyak yaitu ekaliptus dan sengon, karena jenis tersebut dapat tumbuh dengan baik di kawasan industri serta fungsinya cukup baik dalam menyerap polutan.

Jenis ruang terbuka hijau yang terdapat di kawasan industri ini terdiri dari empat jenis RTH yaitu taman, lapangan, jalur hijau jalan, dan daerah penyangga (Buffer zone) (Gambar 12). RTH yang berfungsi buffer zone mendominasi kawasan industri dengan total luas $30 \mathrm{Ha}$. Buffer zone ditanami tegakan pohon dan ground cover. Sedangkan pada taman-taman didominasi oleh jenis tanaman pohon dan tanaman hias. Kawasan industri hanya memiliki dua taman yang berlokasi di pabrik CRM dan pabrik HSM, sedangkan pabrik-pabrik lainnya tidak memiliki taman. Pabrik ini juga memiliki satu lapangan, serta jalur hijau yang berada pada jalan utama di kawasan industri.

Di sebelah selatan kawasan industri terdapat lahan terbuka milik pemerintah kota yang belum dimanfaatkan dengan baik. Untuk saat ini, lahan terbuka tersebut sebagian kecil digunakan warga secara ilegal untuk ditanami tanaman pisang, atau menggembalakan hewan ternak seperti sapi atau kambing karena terdapat banyak rumput-rumputan. Lahan terbuka tersebut dapat dioptimalkan untuk digunakan sebagai green belt yang dapat berfungsi untuk mengurangi dampak industri terhadap jalan raya dan permukiman yang berlokasi di sebelah selatan kawasan industri. 


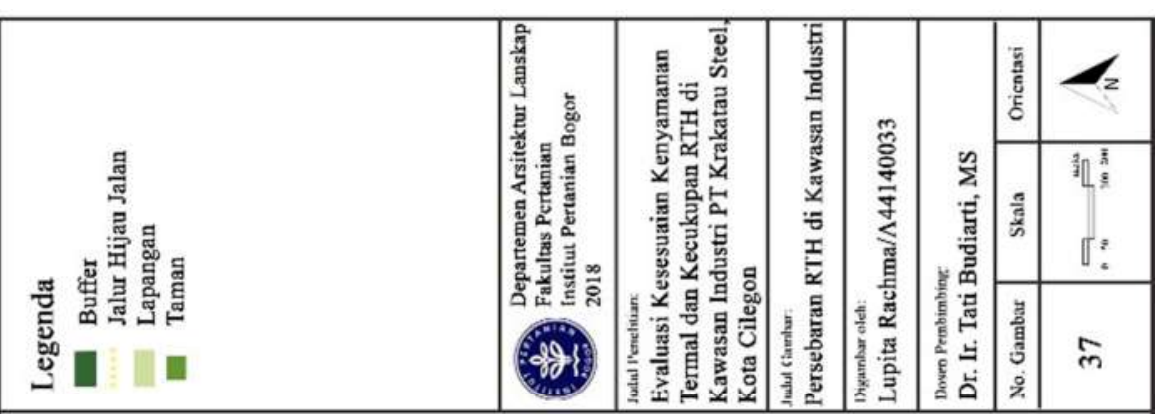

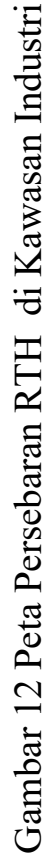




\section{Jenis RTH di Kawasan Industri}

1. Taman CRM

Taman ini berada di samping Pabrik Cold Rolling Mill (CRM) yang berbatasan langsung dengan pabrik tersebut (Gambar 35). Taman terdiri dari tiga bagian yang dipisahkan oleh jalan masuk menuju gedung pabrik CRM (Gambar 13 dan 14). Luas taman pertama $27 \times 15 \mathrm{~m}^{2}$ dan taman kedua $27 \times 25 \mathrm{~m}^{2}$. Kemudian taman lainnya merupakan taman kebugaran dengan luas 27x15 m² (Gambar 15). Di dekat taman terdapat shelter untuk parkir mobil serta di seberang taman sebuah gazebo yang sering digunakan karyawan untuk beristirahat (Gambar 16 dan 17).

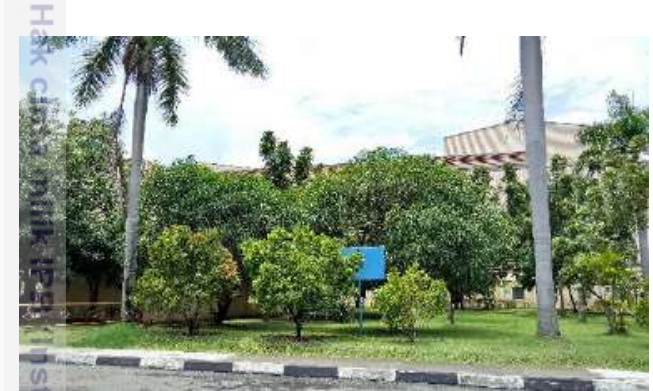

Gambar 13 Taman CRM 1

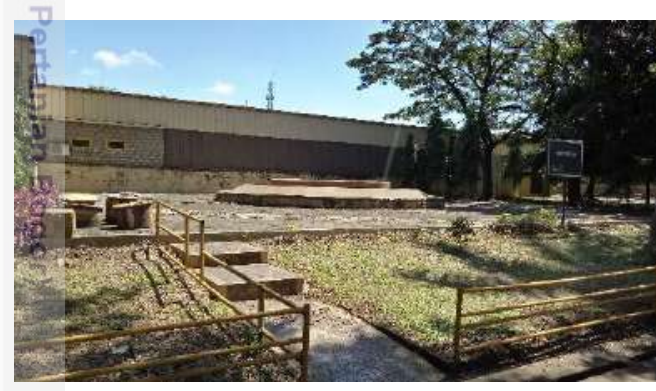

Gambar 15 Taman Kebugaran

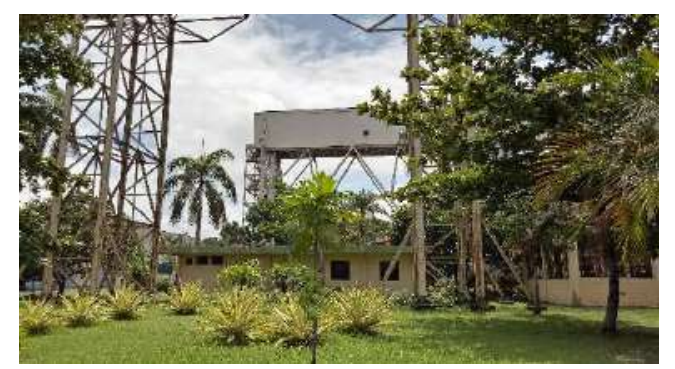

Gambar 14 Taman CRM 2

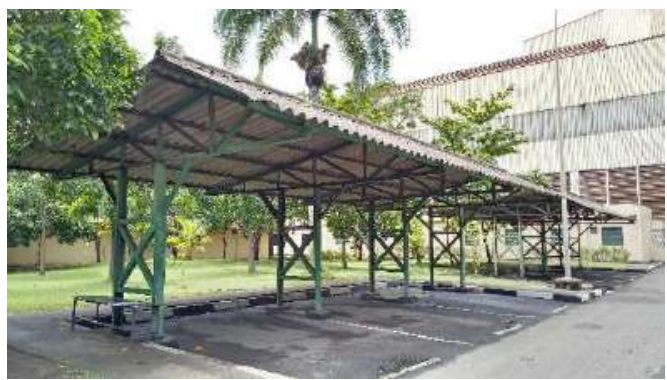

Gambar 16 Shelter untuk Parkir Mobil

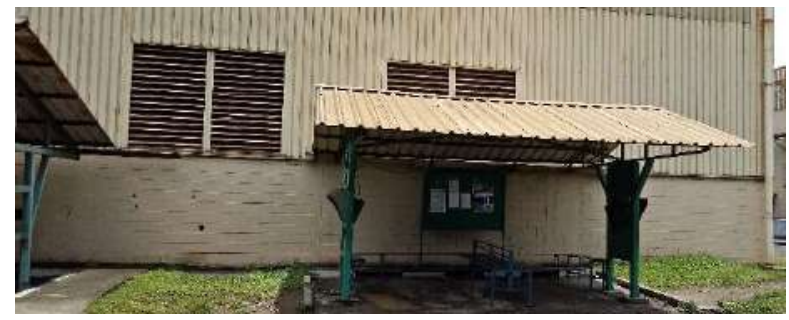

Gambar 17 Gazebo Tempat Karyawan beristirahat

Taman pertama terlihat lebih teduh karena penanaman tanaman yang rapat, terutama dengan adanya keberadaan pohon. Menurut Zahra et al. (2014), penutupan elemen vegetasi yang rimbun pada suatu kawasan lanskap, memberi kesan yang sejuk dan nyaman. Suryowinoto (1997) mengungkapkan bahwa masyarakat cenderung menyukai lanskap dengan kondisi nyaman, teduh, dan adanya naungan tanaman. Keberadaan taman memberi keindahan dan pelembut bagi lingkungan sekitarnya yang terdiri dari bangunan dan perkerasan. Taman CRM ini sering 
dikunjungi karyawan terutama Taman Kebugaran yang banyak dikunjungi karyawan pada pagi hari sebelum mulai kerja. Taman ini ditumbuhi berbagai macam tanaman serta rumput. Berikut daftar tanaman yang ada di Taman CRM (Tabel 13).

Tabel 13 Jenis dan Jumlah Tanaman di Taman CRM

\begin{tabular}{|c|c|c|c|c|}
\hline No. & Nama Latin & Nama Lokal & Jumlah & Satuan \\
\hline 1. & Aerva sanguinolenta & Sambang colok & 25 & Polybag \\
\hline 2. & $\begin{array}{c}\text { Agave angustifolia } \\
\text { marginata }\end{array}$ & Agave & 13 & Polybag \\
\hline 3. & Artocarpus altilis & Sukun & 2 & Pohon \\
\hline 4. & Axonopus compressus & Rumput gajah & 1080 & $\mathrm{~m}^{2}$ \\
\hline 5. & Chlorophytum sp. & Lili paris & 30 & Polybag \\
\hline 6. & Codiaeum sp. & Puring & 1 & Polybag \\
\hline 7. & Cyrtostachis renda & Palem merah & 2 & Pohon \\
\hline 8. & Dictyosperma album & Hurricane palm & 2 & Pohon \\
\hline 9. & Ficus lyrata & Biola cantik & 4 & Pohon \\
\hline 10. & Mangifera indica & Mangga & 7 & Pohon \\
\hline 11. & $\begin{array}{c}\text { Ptychosperma } \\
\text { macarthurii }\end{array}$ & Palem jepang & 1 & Pohon \\
\hline 12. & Roystonea regia & Palem Raja & 4 & Pohon \\
\hline 13. & Swietenia mahagoni & Mahoni & 6 & Pohon \\
\hline 14. & Syzigium oleana & Pucuk merah & 4 & Pohon \\
\hline 15. & Wodyetia bifurcata & Palem ekor tupai & 5 & Pohon \\
\hline
\end{tabular}

Sumber: survei lapang penulis (2018)

\section{Lapangan}

Lapangan merupakan lapangan yang sering dijadikan tempat upacara bagi seluruh karyawan pada tanggal 4 setiap bulan atau pada saat acara peringaatan hari tertentu. Lapangan ini juga digunakan untuk karyawan berolahraga pada hari Jumat, seperti jogging atau sepak bola. Lapangan ditanami rumput bermuda (Cynodon dactilon), dan di sekeliling lapangan terdapat beberapa pohon mangga (Mangifera indica), mahoni (Swietenia mahogany), dan ki hujan (Samanea saman). Menurut Booth (1990), pohon dapat meningkatkan kualitas udara, mencegah erosi, meningkatkan kualitas air, dan memodifikasi iklim. Selain itu keberadaan pohon juga mampu menghadirkan kenyamanan pengguna.

Rumput Bermuda (Cynodon dactylon) banyak digunakan di lapangan Indonesia yang awalnya dirancang untuk lapangan golf. Cynodon dactylon merupakan rumput perennial musim hangat yang tumbuh pada iklim tropis dan subtropis. Rumput Bermuda memiliki karakteristik hijau keabu-abuan, bertekstur halus, mempunyai $1 \frac{1}{4}$-inchwide, daun berbulu tajam, bercabang, dan penyebarannya cepat. Rumput Bermuda cukup mudah tumbuh dan dapat berfungsi sebagai penutup tanah pada lapangan 2 golf, lapangan sepak bola, halaman rumah, dan dapat memperindah lanskap (Turgeon 2002). Keadaan rumput di lapangan sangat hijau ketika penulis pertama kali mengunjungi tapak, tapi dua minggu kemudian sebagian rumput sudah mati (Gambar 18 dan Gambar 19). Hal ini bisa disebabkan karena iklim maupun irigasi yang kurang baik. 


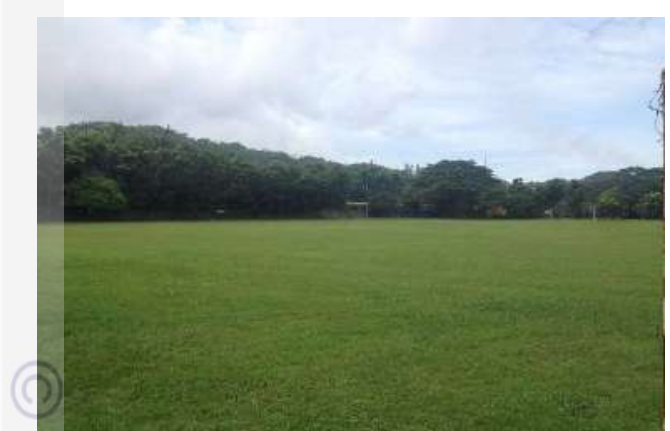

Gambar 18 Kondisi Awal Lapangan

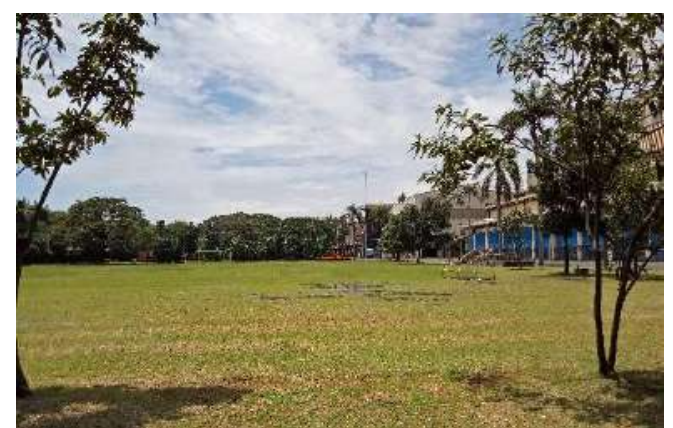

Gambar 19 Kondisi Lapangan Dua Minggu Kemudian

Rumput lapangan yang kering dalam jangka waktu yang sangat cepat tentunya karena pengaruh iklim, tetapi irigasi yang kurang baik juga menjadi faktor penentu. Ramadani (2013), Irigasi dibutuhkan untuk memperbaiki toleransi rumput untuk hidup pada lapangan. Hal ini dikarenakan pertumbuhan rumput terdiri dari lebih dari 75 persen dari berat air. Penyiraman yang baik yaitu menggunakan sprinkler yang dikendalikan secara otomatis dengan satelit kontrol yang dapat diatur waktunya. Menurut Ramadani (2013), sistem sprinkler otomatis paling baik digunakan untuk mengairi seluruh jenis rumput pada lapangan.

Menurut Ramadani (2013), waktu yang paling efisien untuk menyiram ialah antara pukul 22.00 dan pukul 08.00 karena membatasi jumlah jaringan daun tetap lembab dan mengurangi penguapan. Waktu penyiraman rumput lapangan ini sebaiknya dilakukan pada waktu tersebut. Selain itu, pihak pengelola perlu mengatur volume air untuk irigasi rumput tersebut. Menurut Turgeon (2002), kesesuaian volume air irigasi dapat ditentukan dari kedalaman akar rumput menembus tanah dan volume dari perakaran tersebut. Panjang akar yang semakin panjang dapat menjadi indikator kesuburan dan kekuatan rumput karena mampu memegang media dan menyerap unsur hara lebih baik.

\section{Taman Masjid HSM}

Taman ini berada di samping Pabrik Hot Strip Mill (HSM) yang berbatasan langsung dengan pabrik tersebut (Gambar 36). Taman berada di sekeliling masjid. Di dalam taman terdapat jembatan dan badan air berupa kolam (Gambar 20 dan 21). Keberadaan badan air dapat mendinginkan suhu udara di sekitarnya yang meningkatkan kenyamanan di dalam taman tersebut. Bagian samping kanan masjid terdapat tegakan pohon mangga dengan penanaman yang cukup rapat dan memberi keteduhan tetapi kondisinya masih kurang rapi (Gambar 22). Taman masjid ini dilengkapi pedestrian track, tetapi kondisinya kurang baik (Gambar 23).

Masjid HSM merupakan salah satu dari dua masjid yang berada di Kawasan Industri PT KS, yang sering digunakan sebagai tempat beribadah karyawan yang beragama islam, terutama saat ibadah Sholat Jumat. Banyak karyawan yang menghabiskan waktu istirahatnya di masjid HSM karena kondisinya yang nyaman, tetapi taman hanya menjadi display saja karena belum terdapat fasilitas yang memadai seperti tempat duduk, serta kebersihan dan kerapihan taman tersebut masih minim. Dari bagian depan, taman terlihat rapi dan bersih, dengan penanaman 
yang tertata (Gambar 24 dan 25). Luas taman HSM yaitu $500 \mathrm{~m}^{2}$ dan luas masjid yaitu $500 \mathrm{~m}^{2}$. Berikut daftar tanaman yang ada di Taman CRM (Tabel 14).

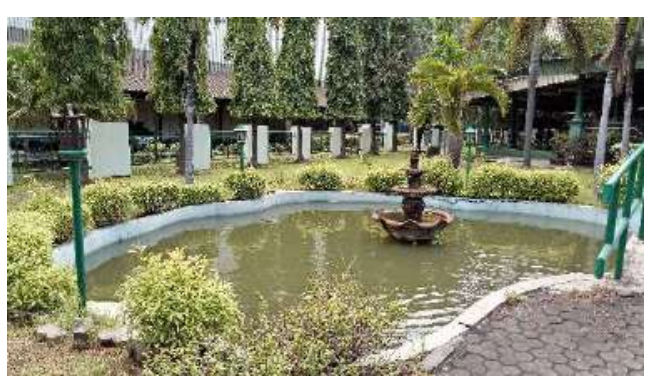

Gambar 20 Badan Air di Taman HSM

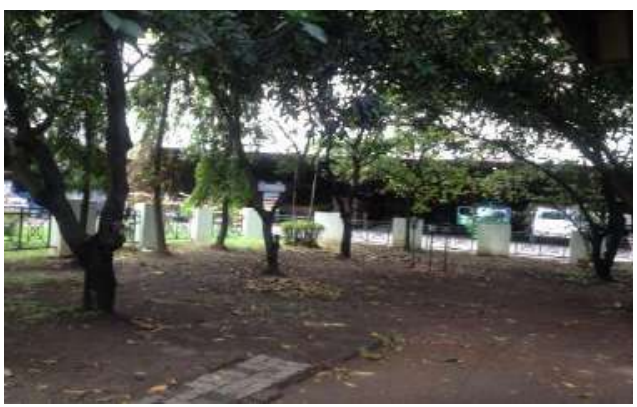

Gambar 22 Kondisi Bagian Samping

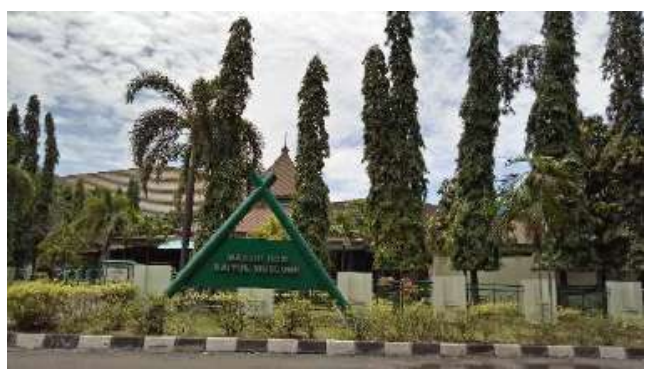

Gambar 24 Tampak Depan Masjid

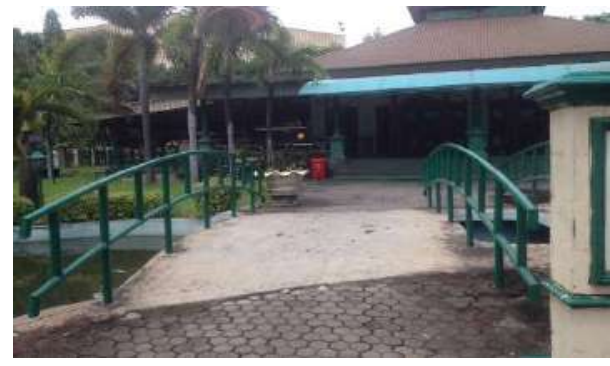

Gambar 21 Jembatan di Taman HSM

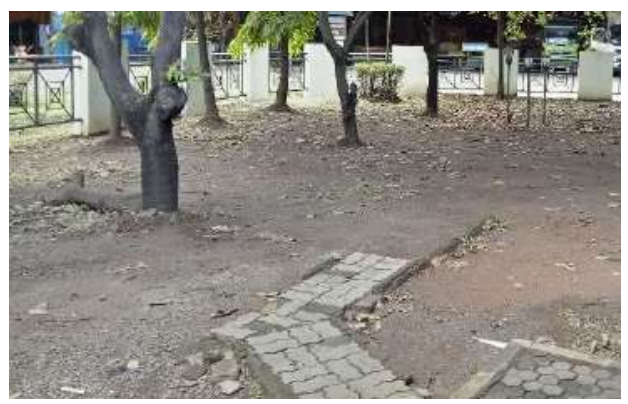

Gambar 23 Kondisi Pedestrian Track

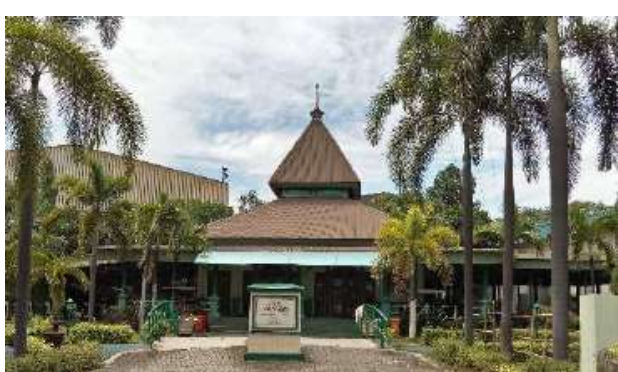

Gambar 25 Masjid HSM

Tabel 14 Jenis dan Jumlah Tanaman di Taman Masjid HSM

\begin{tabular}{ccccc}
\hline No. & Nama Latin & Nama Lokal & Jumlah & Satuan \\
\hline 1. & Acalypha macrophylla & Teh-tehan & 28 & Polybag \\
\hline 2. & Axonopus compressus & Rumput gajah & 35 & $\mathrm{~m}^{2}$ \\
\hline 3. & Corphya utan & Gebang & 3 & Pohon \\
\hline 4. & Dictyosperma album & Hurricane palm & 1 & Pohon \\
\hline 5. & Ixora javanica & Soka jawa & 10 & Polybag \\
\hline 6. & Mangifera indica & Mangga & 12 & Pohon \\
\hline 7. & Mascarena legeniaulis & Palem botol & 3 & Pohon \\
\hline
\end{tabular}


Tabel 14 (lanjutan) Jenis dan Jumlah Tanaman di Taman Masjid HSM

\begin{tabular}{ccccc}
\hline 8. & Polyathia longifolia & Glodogan tiang & 25 & Pohon \\
\hline 9. & Roystonea regia & Palem raja & 10 & Pohon \\
\hline 10. & Swietenia mahogany & Mahoni & 3 & Pohon \\
\hline 11. & Wodyetia bifurcata & Palem ekor tupai & 9 & Pohon \\
\hline \multicolumn{2}{l}{ Sumber: survei lapang penulis (2018) }
\end{tabular}

4. Jalur Hijau Jalan

Jalur hijau jalan dapat berperan untuk menaungi jalan, pengarah, serta mengurangi polusi akibat emisi dari kendaraan, yang antara lain berbentuk gas pencemar dan partikel padat. Seperti disebutkan oleh Grey dan Deneke (1978), tanaman dapat mengurangi konsentrasi polutan di udara melalui pelepasan oksigen dan pencampuran antara udara tercemar dengan udara bersih. Tanaman dapat mengurangi polusi udara melalui penyerapan gas pencemar dan penjerapan partikel. Karena itu, perkembangan jalan juga perlu memperhatikan pengembangan jalur hijau jalan. Jalur hijau jalan pada tapak terdapat di sebagian besar jalan utama di kawasan industri PT Krakatau Steel (Gambar 37). Vegetasi pada jalur penanaman tepi jalan meliputi jenis-jenis pohon. Vegetasi yang digunakan terdiri dari tanaman Glodokan Tiang (Polyathia longifolia), Ki hujan (Samanea saman), atau Palm Raja (Roystonea regia). Konfigurasi tanaman ini dapat menangui jalan, memofifikasi iklim mikro dan memberi kenyamanan kepada pengguna jalan. Berikut jalur hijau jalan di HSE (Gambar 26), CRM (Gambar 27), HSM (Gambar 28), WRM (Gambar 29).

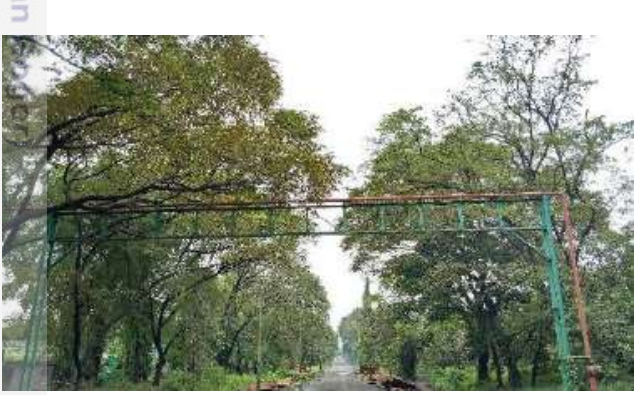

Gambar 26 Jalur Hijau Jalan di HSE

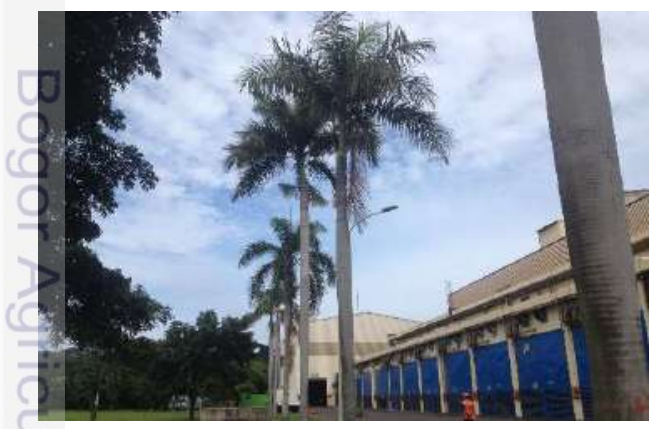

Gambar 28 Jalur Hijau Jalan di HSM

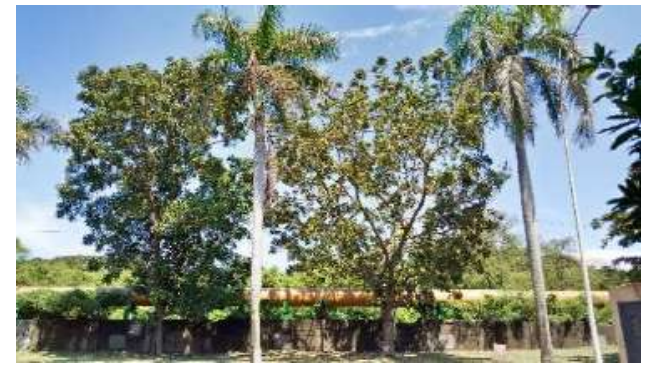

Gambar 27 Jalur hijau Jalan di CRM

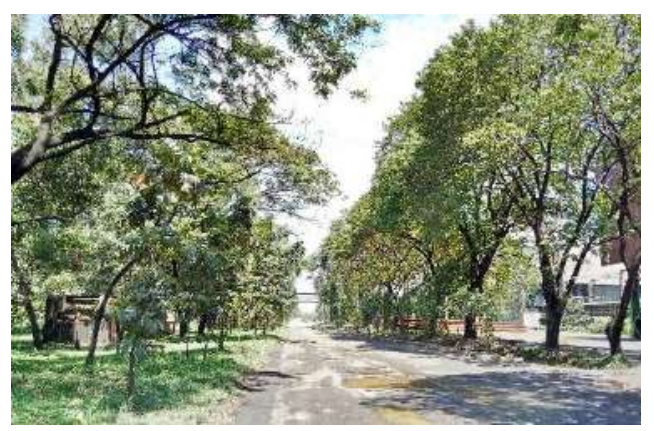

Gambar 29 Jalur Hijau Jalan di WRM 
5. Daerah penyangga (Buffer zone)

Daerah penyangga mengelilingi setiap keenam pabrik yang berfungsi sebagai daerah jerapan polusi udara dan debu yang berasal dari pabrik (Gambar 38). Daerah penyangga ini terdiri dari vegetasi berupa tegakan pohon yang rata-rata berumur lebih dari 20 tahun. Jarak penanaman antar tanaman yaitu 4 hingga 5 meter. Luas daerah penyangga seluas $30 \mathrm{Ha}$. Daerah penyangga ini sudah direncanakan dalam Master Plan kawasan industri sebelum pembangunan kawasan industri. Akan tetapi perbanyakan penanaman pohon di daerah penyangga mulai dilakukan sejak tahun 2011 untuk mewujudkan target PT KS menjadi green industry. Semenjak pabrik ini beroperasi terdapat beberapa tanaman yang mati dan kemudian diganti dengan tanaman yang baru yang berasal dari pembibitan milik PT KS. Dari hasil pengamatan, daerah penyangga ini juga memiliki masalah yaitu kondisi beberapa tanaman dengan daun yang terkena penyakit. Terdapat juga alih fungsi lahan yang menyebabkan lahan daerah penyangga beralih fungsi menjadi pabrik-pabrik baru, yaitu project blast furnace yang hingga saat ini masih dalam tahap pembangunan. Berikut daftar jenis pohon yang terdapat pada daerah penyangga (Tabel 15).

Tabel 15 Jenis Tanaman di Daerah Penyangga Kawasan Industri

\begin{tabular}{cccc}
\hline No. & Nama Latin & Nama Lokal & Satuan \\
\hline 1. & Adenanthera pavonina & Saga & Pohon \\
\hline 2. & Acacia longifolia & Akasia & Pohon \\
\hline 3. & Albizia chinensis & Sengon & Pohon \\
\hline 4. & Bambusa vulgaris & Bambu kuning & Pohon \\
\hline 5. & Casuarina junghuhniana & Cemara angin & Pohon \\
\hline 6. & Eucalyptus spp. & Ekaliptus & Pohon \\
\hline 7. & Ficus benjamina & Beringin & Pohon \\
\hline 8. & Mimusops elengi & Tanjung & Pohon \\
\hline 9. & Polyathia longifolia & Glodogan & Pohon \\
\hline 10. & Pterocarpus indicus & Angsana & Pohon \\
\hline 11. & Samanea saman & Ki hujan & Pohon \\
\hline 12. & Swietenia macrophyla & Mahoni daun besar & Pohon \\
\hline 13. & Swietenia mahogany & Mahoni daun kecil & Pohon \\
\hline \multicolumn{5}{r}{} & Jumlah Tanaman & & $\mathbf{6 4 . 7 6 8}$ Pohon \\
\hline
\end{tabular}

Sumber: Divisi General Affair PT Krakatau Steel (2018)

Daerah penyangga ini terdiri dari RTH Buffer Pabrik HSM, RTH Buffer Pabrik WRM, RTH Buffer Pabrik DRP, RTH Buffer Pabrik BSP, dan RTH Kantor HSE. RTH Pabrik CRM terdiri dari tanaman Sengon (Albizia chinensis), Beringin (Ficus benjamina), Angsana (Polyathia longifolia), Ki hujan (Samanea saman), dan Mahoni (Swietenia mahagoni). RTH Pabrik HSM terdiri dari tanaman Ki hujan 
(Samanea saman), Mahoni (Swietenia mahagoni) dan Glodogan (Polyathia longifolia) yang ditanam secara rapat dan mengisi sebagian area terbuka pabrik HSM (Gambar 30). RTH Pabrik WRM terdiri dari tanaman Ki hujan (Samanea saman), Ekaliptus (Eucalyptus spp.), dan Mahoni daun lebar (Swietenia macrophyla). yang berada di antara pabrik dan jalan pabrik HSM (Gambar 31). RTH Pabrik DRP ditengahnya dilewati parit buatan untuk keperluan aktivitas pabrik (Gambar 32), terdiri dari tanaman Akasia (Acacia longifolia), Bambu (Bambusa vulgaris), Cemara angin (Casuarina junghuhniana), dan Ki hujan (Samanea saman). RTH Pabrik BSP ditanami Saga (Adenanthera pavonina), Angsana (Pterocarpus indicus) dan Ki hujan (Samanea saman) (Gambar 33). Pada RTH HSE ditanami Mahoni daun lebar (Swietenia macrophyla), Mahoni (Swietenia mahogany), dan Tanjung (Mimusops elengi) yang cukup luas dan ditengahtengahnya terdapat hamparan rumput (Gambar 34).

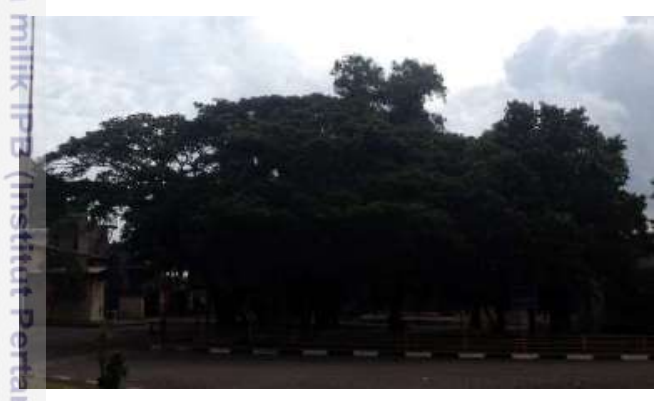

Gambar 30 RTH Pabrik HSM

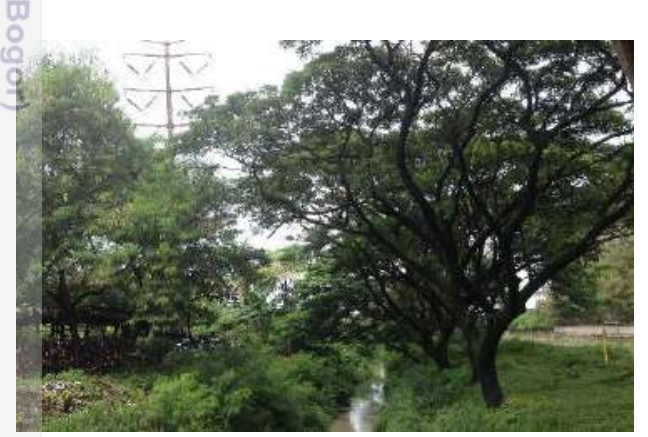

Gambar 32 RTH Pabrik DRP

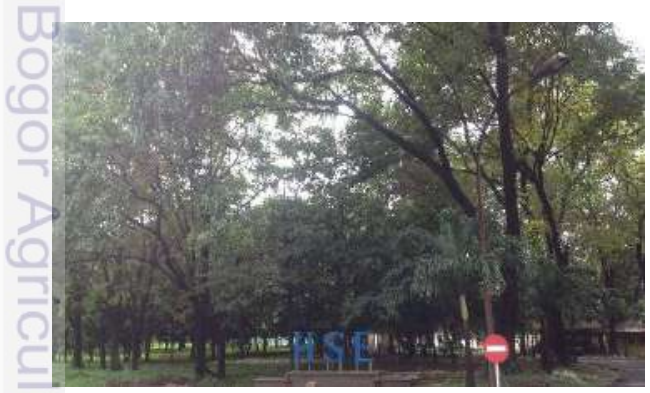

Gambar 34 RTH Kantor HSE

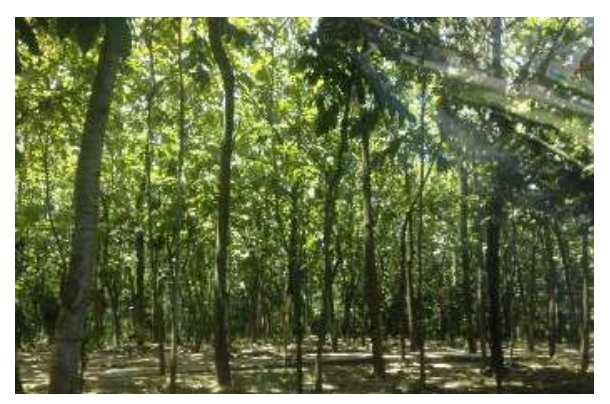

Gambar 31 RTH Pabrik WRM

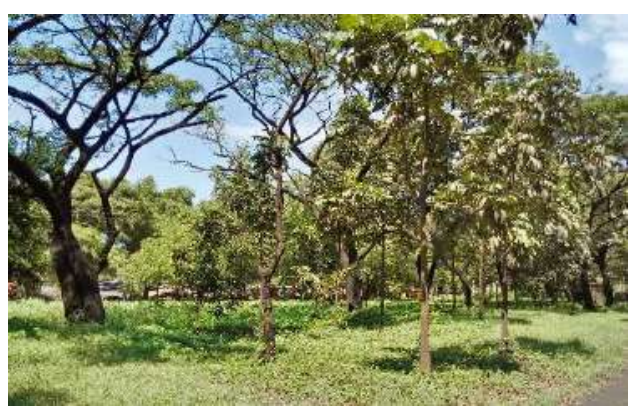

Gambar 33 RTH Pabrik BSP 


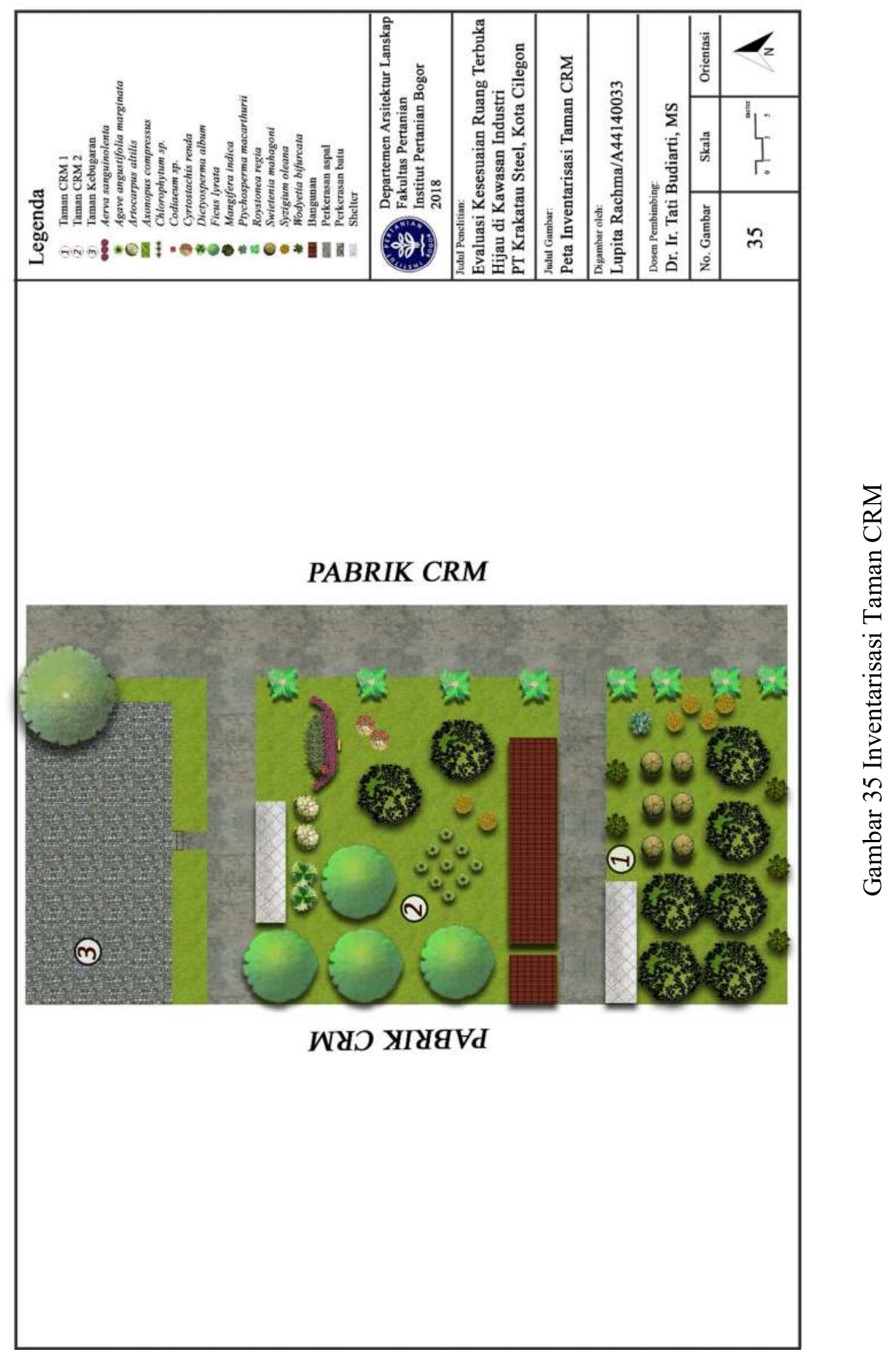



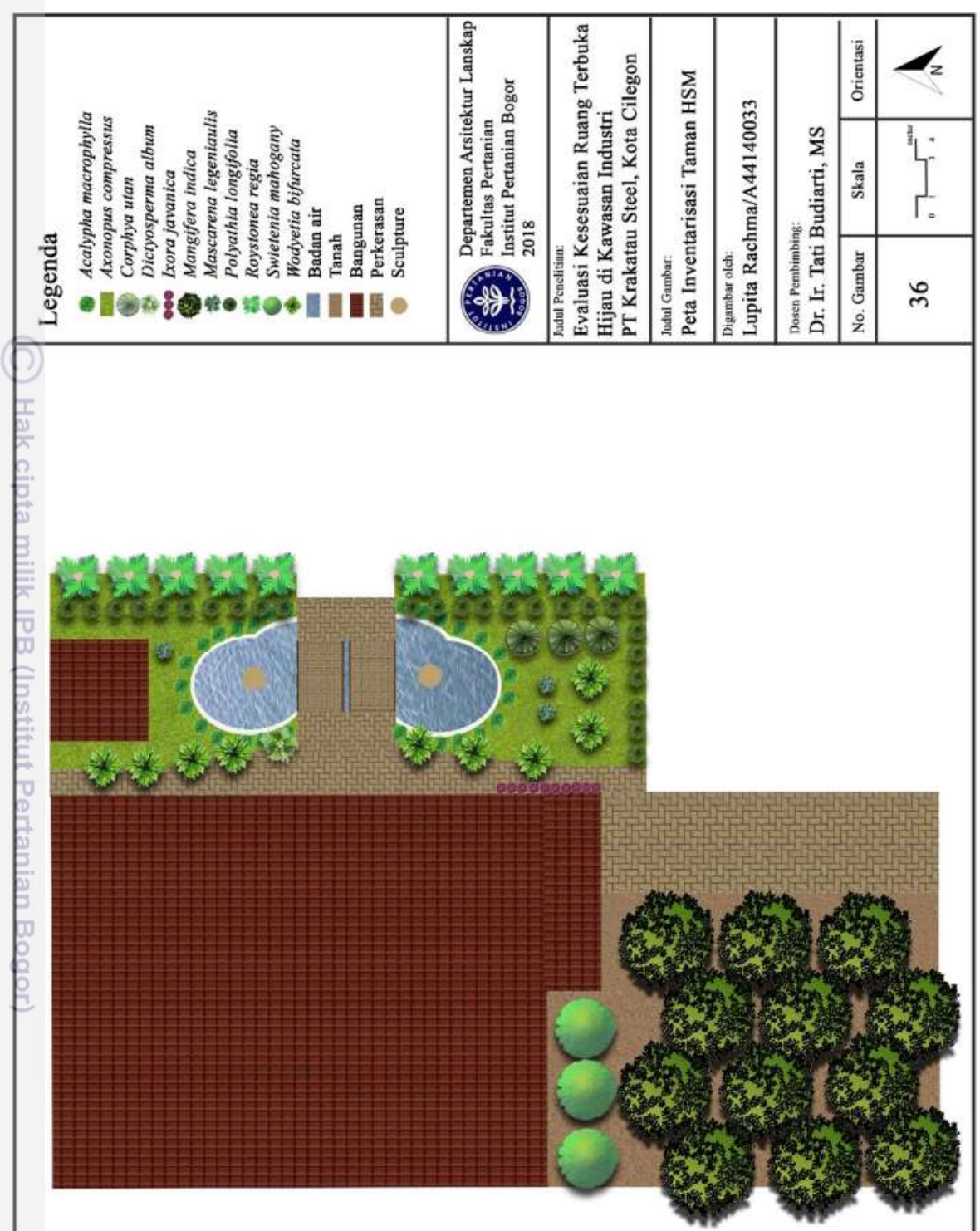

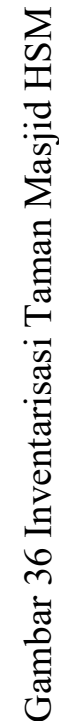




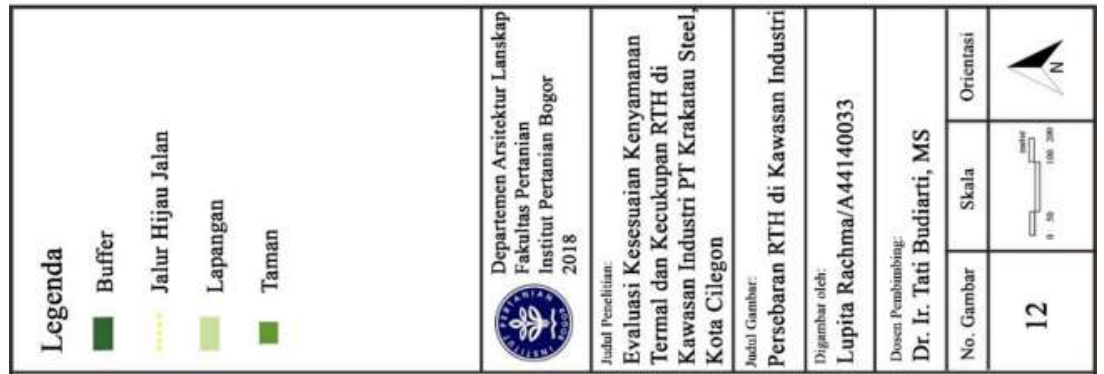

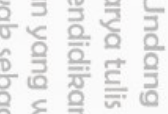

을을 홍
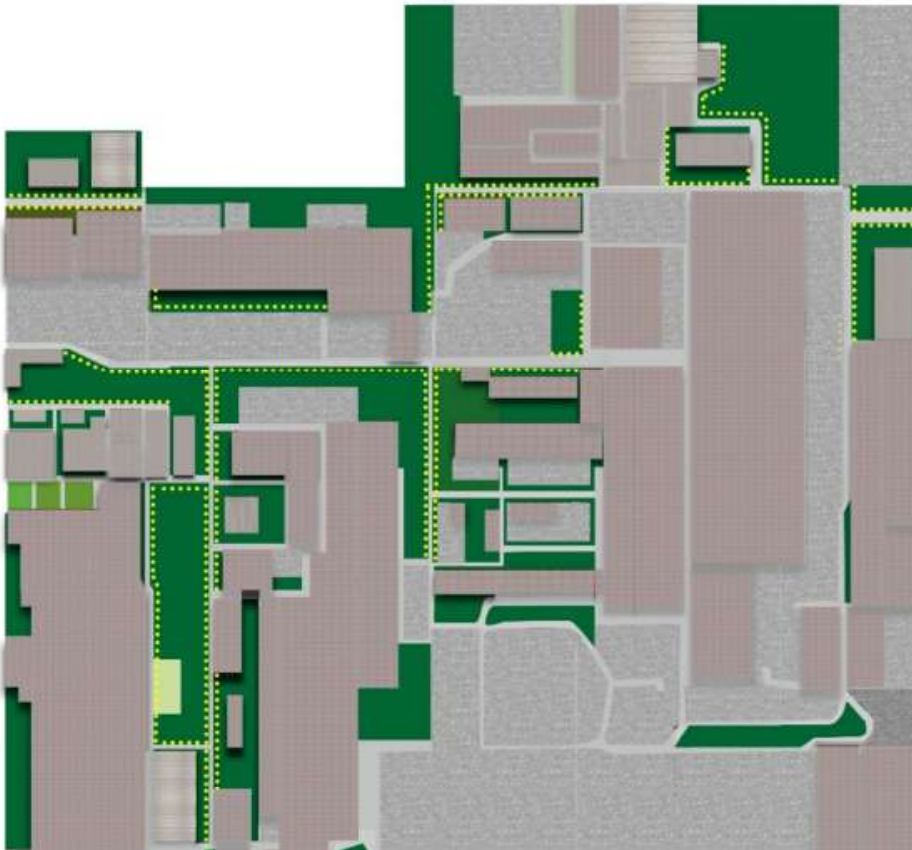

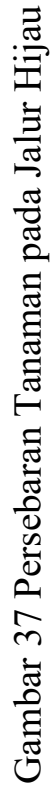



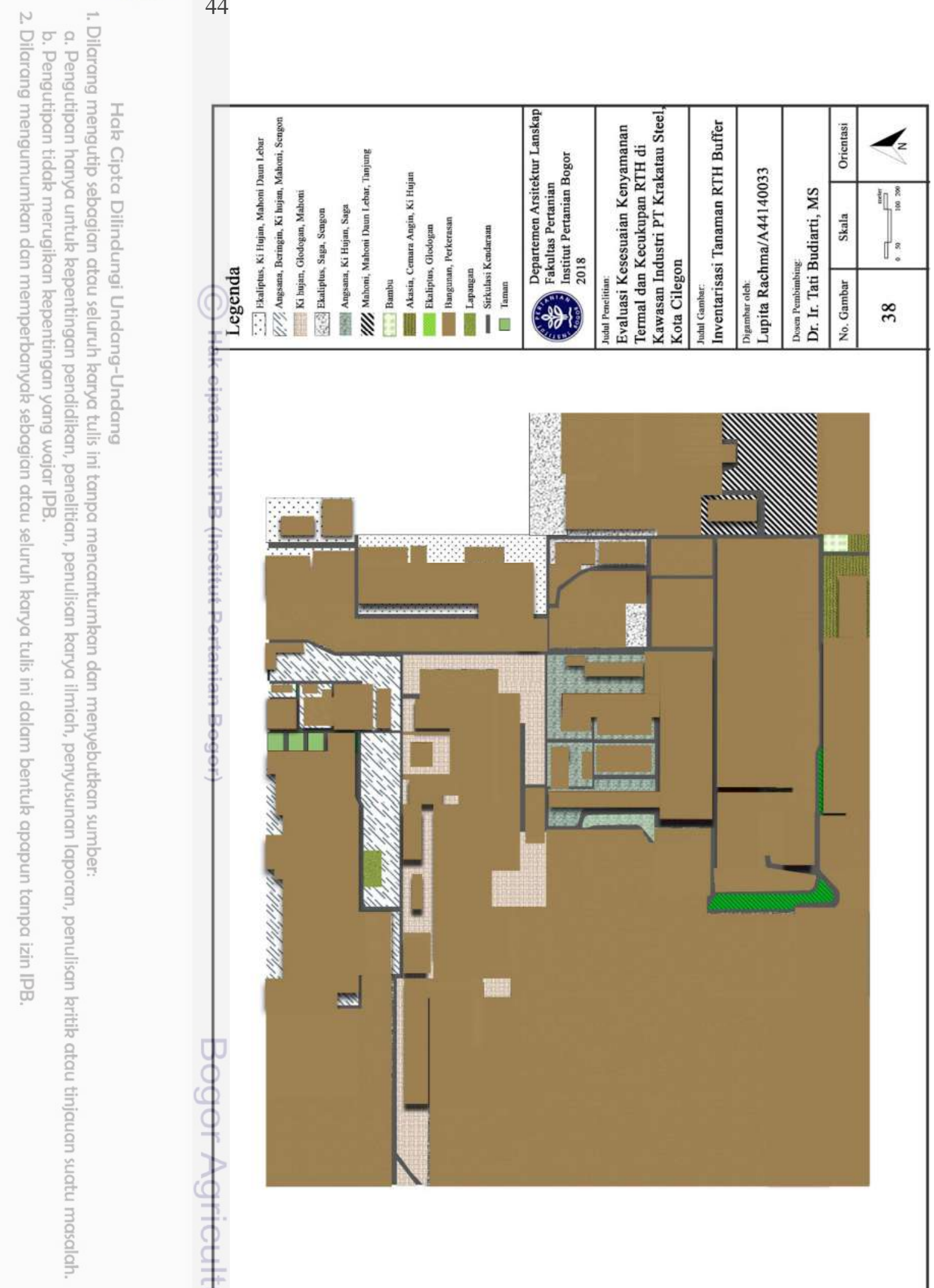

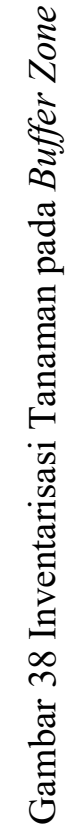




\section{Analisis Kenyamanan Termal}

Analisis kenyamanan termal dilakukan untuk mengetahui tingkat kenyamanan di kawasan industri PT KS. Kenyamanan dinilai dari suhu dan kelembaban udara sekitar. Suhu berbanding terbalik dengan kelembaban udara untuk menciptakan kenyamanan. Semakin tinggi suhu udara di sekitar maka kelembaban udara semakin kecil. Nilai kenyamanan secara termal dapat diukur dengan alat yang disebut termohigrometer. Pengukuran dilakukan di enam lokasi yaitu Taman CRM, Taman Masjid HSM, Jalur hijau jalan, RTH Pabrik DRP, Lapangan dan RTH Kantor HSE.

Pengukuran dilakukan dengan kondisi naungan pohon dan tanpa naungan pohon, dengan waktu pengukuran pagi, siang, dan sore hari pada kondisi di dalam RTH yaitu di bawah naungan dan di luar RTH yaitu di perkerasan. Setelah didapatkan hasil pengukuran suhu, selanjutnya dihitung nilai Temperature Humidity Index (THI) untuk menganalisis kenyamanannya. THI diperoleh dari hasil perhitungan dengan menggunakan rumus Nieuwolt yang telah dijelaskan dalam metodologi. Hasil pengukuran suhu dan perolehan nilai THI dapat dilihat pada tabel 16, 17, 18, 19, 20, dan 21 .

Tabel 16 Pengukuran Suhu, Kelembaban, dan Nilai THI pada Taman CRM

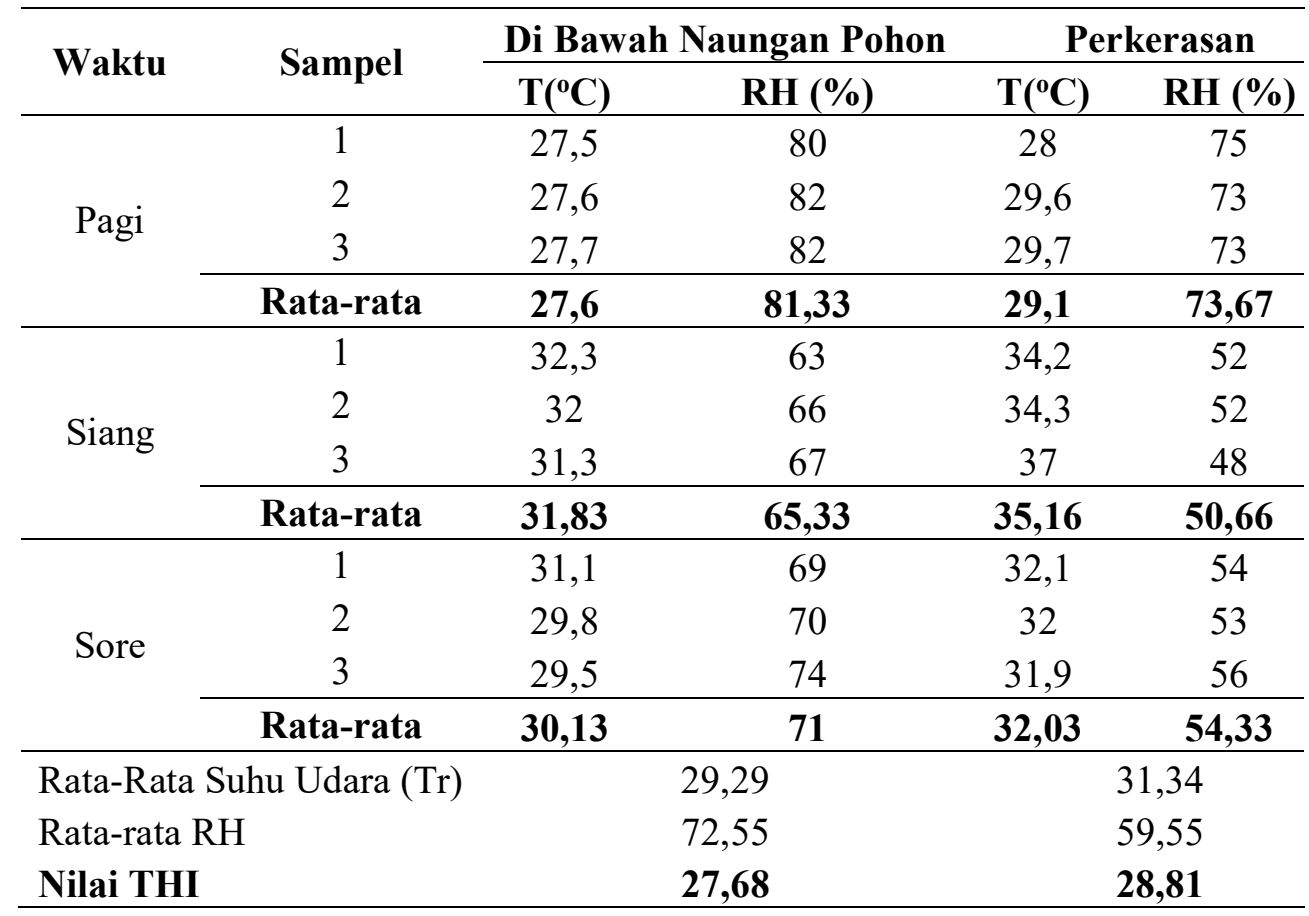


Tabel 17 Pengukuran Suhu, Kelembaban, dan Nilai THI pada Taman Masjid HSM

\begin{tabular}{|c|c|c|c|c|c|}
\hline \multirow{2}{*}{ Waktu } & \multirow{2}{*}{ Sampel } & \multicolumn{2}{|c|}{ Di Bawah Naungan Pohon } & \multicolumn{2}{|c|}{ Perkerasan } \\
\hline & & $\mathbf{T}\left({ }^{\circ} \mathrm{C}\right)$ & RH (\%) & $\mathbf{T}\left({ }^{\circ} \mathbf{C}\right)$ & RH (\%) \\
\hline \multirow{4}{*}{ Pagi } & 1 & 28,6 & 78 & 28,9 & 75 \\
\hline & 2 & 27,8 & 81 & 29,9 & 73 \\
\hline & 3 & 27,6 & 82 & 30,6 & 73 \\
\hline & Rata-rata & 28 & 80,33 & 29,8 & 72,67 \\
\hline \multirow{4}{*}{ Siang } & 1 & 31,8 & 53 & 32,8 & 52 \\
\hline & 2 & 30,9 & 58 & 32,6 & 57 \\
\hline & 3 & 30,8 & 60 & 33,1 & 50 \\
\hline & Rata-rata & 31,16 & 57 & 32,5 & 53 \\
\hline \multirow{4}{*}{ Sore } & & 30,7 & 59 & 31,4 & 60 \\
\hline & & 30,2 & 59 & 32,6 & 52 \\
\hline & & 30,1 & 60 & 32,3 & 54 \\
\hline & Rata-rata & 30,3 & 59,33 & 32,10 & 55,33 \\
\hline \multicolumn{2}{|c|}{ Rata-Rata Suhu Udara (Tr) } & \multicolumn{2}{|r|}{30,93} & \multicolumn{2}{|c|}{31,05} \\
\hline \multicolumn{2}{|c|}{ Rata-rata RH } & \multicolumn{2}{|r|}{65,55} & \multicolumn{2}{|c|}{60,33} \\
\hline \multicolumn{2}{|l|}{ Nilai THI } & \multicolumn{2}{|r|}{28,79} & \multicolumn{2}{|c|}{28,58} \\
\hline
\end{tabular}

Tabel 18 Pengukuran Suhu, Kelembaban, dan Nilai THI pada Jalur Hijau Jalan

\begin{tabular}{|c|c|c|c|c|c|}
\hline \multirow{2}{*}{ Waktu } & \multirow{2}{*}{ Sampel } & \multicolumn{2}{|c|}{ Di Bawah Naungan Pohon } & \multicolumn{2}{|c|}{ Perkerasan } \\
\hline & & $\mathbf{T}\left({ }^{\circ} \mathbf{C}\right)$ & RH (\%) & $\mathbf{T}\left({ }^{\circ} \mathrm{C}\right)$ & RH (\%) \\
\hline \multirow{4}{*}{ Pagi } & 1 & 27,9 & 77 & 28,5 & 75 \\
\hline & 2 & 27,9 & 79 & 29,2 & 75 \\
\hline & 3 & 28 & 78 & 29,6 & 75 \\
\hline & Rata-rata & 27,93 & 78 & 29,1 & 75 \\
\hline \multirow{4}{*}{ Siang } & 1 & 32 & 56 & 32,7 & 55 \\
\hline & 2 & 31,8 & 52 & 33,4 & 52 \\
\hline & 3 & 32,7 & 54 & 33,9 & 51 \\
\hline & Rata-rata & 32,16 & 54 & 33,33 & 52,66 \\
\hline \multirow{4}{*}{ Sore } & 1 & 31,5 & 58 & 32,3 & 55 \\
\hline & 2 & 31,0 & 61 & 32,0 & 56 \\
\hline & 3 & 31,9 & 55 & 32,7 & 54 \\
\hline & Rata-rata & 31,46 & 58 & 32,3 & 55 \\
\hline \multicolumn{2}{|c|}{ Rata-Rata Suhu Udara (Tr) } & \multicolumn{2}{|c|}{29,87} & \multicolumn{2}{|c|}{30,95} \\
\hline \multicolumn{2}{|c|}{ Rata-rata $\mathrm{RH}$} & \multicolumn{2}{|c|}{63,33} & \multicolumn{2}{|c|}{60,88} \\
\hline \multicolumn{2}{|c|}{ Nilai THI } & \multicolumn{2}{|c|}{27,67} & \multicolumn{2}{|c|}{28,53} \\
\hline
\end{tabular}


Tabel 19 Pengukuran Suhu, Kelembaban, dan Nilai THI pada RTH Pabrik DRP

\begin{tabular}{|c|c|c|c|c|c|}
\hline \multirow{2}{*}{ Waktu } & \multirow{2}{*}{ Sampel } & \multicolumn{2}{|c|}{ Di Bawah Naungan Pohon } & \multicolumn{2}{|c|}{ Perkerasan } \\
\hline & & $\mathbf{T}\left({ }^{\circ} \mathrm{C}\right)$ & RH (\%) & $\mathbf{T}\left({ }^{\circ} \mathrm{C}\right)$ & RH (\%) \\
\hline \multirow{4}{*}{ Pagi } & 1 & 27,3 & 79 & 29,1 & 77 \\
\hline & 2 & 27,2 & 80 & 29,7 & 78 \\
\hline & 3 & 28,1 & 80 & 29,5 & 77 \\
\hline & Rata-rata & $\mathbf{2 7 , 5 3}$ & 79,67 & 29,43 & 77,33 \\
\hline \multirow{4}{*}{ Siang } & 1 & 32,6 & 56 & 32 & 56 \\
\hline & 2 & 30,7 & 59 & 33 & 54 \\
\hline & 3 & 30,6 & 58 & 34,1 & 50 \\
\hline & Rata-rata & 31,3 & 57,67 & 33 & 53,33 \\
\hline \multirow{4}{*}{ Sore } & 1 & 31 & 60 & 31,1 & 59 \\
\hline & 2 & 30 & 65 & 32,3 & 56 \\
\hline & 3 & 30,5 & 70 & 32,6 & 54 \\
\hline & Rata-rata & 30,5 & 65 & 32 & 56,33 \\
\hline \multicolumn{2}{|c|}{ Rata-Rata Suhu Udara (Tr) } & \multicolumn{2}{|c|}{29,21} & \multicolumn{2}{|c|}{30,96} \\
\hline \multicolumn{2}{|c|}{ Rata-rata $\mathrm{RH}$} & \multicolumn{2}{|c|}{67,44} & \multicolumn{2}{|c|}{62,33} \\
\hline \multicolumn{2}{|c|}{ Nilai THI } & \multicolumn{2}{|c|}{27,31} & \multicolumn{2}{|c|}{28,63} \\
\hline
\end{tabular}

Tabel 20 Pengukuran Suhu, Kelembaban, dan Nilai THI pada RTH Kantor HSE

\begin{tabular}{|c|c|c|c|c|c|}
\hline \multirow{2}{*}{ Waktu } & \multirow{2}{*}{ Sampel } & \multicolumn{2}{|c|}{ Di Bawah Naungan Pohon } & \multicolumn{2}{|c|}{ Perkerasan } \\
\hline & & $\mathbf{T}\left({ }^{\circ} \mathrm{C}\right)$ & RH (\%) & $\mathrm{T}\left({ }^{\circ} \mathrm{C}\right)$ & RH (\%) \\
\hline \multirow{4}{*}{ Pagi } & 1 & 27,9 & 80 & 27,5 & 75 \\
\hline & 2 & 26,9 & 82 & 27,3 & 77 \\
\hline & 3 & 26,6 & 84 & 27,3 & 78 \\
\hline & Rata-rata & 27,13 & 82 & 27,36 & 79,67 \\
\hline \multirow{4}{*}{ Siang } & 1 & 32 & 60 & 32,2 & 53 \\
\hline & 2 & 30,6 & 69 & 32,8 & 50 \\
\hline & 3 & 30,1 & 71 & 32,7 & 52 \\
\hline & Rata-rata & 30,9 & 66,67 & 32,56 & 51,67 \\
\hline \multirow{4}{*}{ Sore } & 1 & 29,2 & 73 & 30 & 60 \\
\hline & 2 & 29 & 74 & 30,9 & 58 \\
\hline & 3 & 28,4 & 76 & 29,8 & 57 \\
\hline & Rata-rata & 28,86 & 74,33 & 30,23 & 58,33 \\
\hline \multirow{2}{*}{\multicolumn{2}{|c|}{$\begin{array}{l}\text { Rata-Rata Suhu Udara (Tr) } \\
\text { Rata-rata RH }\end{array}$}} & \multicolumn{2}{|c|}{28,50} & \multicolumn{2}{|c|}{29,38} \\
\hline & & & & \multicolumn{2}{|c|}{63,22} \\
\hline \multicolumn{2}{|c|}{ Nilai THI } & \multicolumn{2}{|c|}{27} & & 7,16 \\
\hline
\end{tabular}


Tabel 21 Pengukuran Suhu, Kelembaban, dan Nilai THI pada Lapangan

\begin{tabular}{|c|c|c|c|c|c|c|}
\hline \multirow{2}{*}{\multicolumn{2}{|c|}{ Waktu }} & \multirow{2}{*}{ Sampel } & \multicolumn{2}{|c|}{ Di Bawah Naungan Pohon } & \multicolumn{2}{|c|}{ Perkerasan } \\
\hline & & & $\mathbf{T}\left({ }^{\circ} \mathbf{C}\right)$ & RH (\%) & $\mathbf{T}\left({ }^{\circ} \mathrm{C}\right)$ & RH (\%) \\
\hline \multirow{4}{*}{\multicolumn{2}{|c|}{ Pagi }} & 1 & 27,9 & 71 & 30,7 & 60 \\
\hline & & 2 & 26,9 & 75 & 29,9 & 62 \\
\hline & & 3 & 26,6 & 77 & 29,7 & 62 \\
\hline & & Rata-rata & 27,13 & 74,33 & 30,1 & 61,33 \\
\hline \multirow{4}{*}{\multicolumn{2}{|c|}{ Siang }} & 1 & 30,9 & 60 & 34,3 & 46 \\
\hline & & 2 & 30,5 & 62 & 34 & 46 \\
\hline & & 3 & 30 & 62 & 33,33 & 45 \\
\hline & & Rata-rata & 30,46 & 68,33 & 33,86 & 45,67 \\
\hline$\frac{\overline{\bar{\lambda}}}{\overline{\bar{\lambda}}}$ & \multirow{4}{*}{ Sore } & 1 & 30,7 & 60 & 32 & 50 \\
\hline 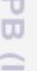 & & 2 & 29,9 & 62 & 30,6 & 52 \\
\hline $\bar{c}_{\substack{n\\
}}$ & & 3 & 29,7 & 62 & 30,1 & 53 \\
\hline 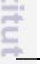 & & Rata-rata & 30,1 & 68,33 & 30,9 & 51,66 \\
\hline \multicolumn{3}{|c|}{ Rata-Rata Suhu Udara (Tr) } & \multicolumn{2}{|c|}{28,70} & \multicolumn{2}{|c|}{31,24} \\
\hline \multicolumn{3}{|c|}{ Rata-rata RH } & \multicolumn{2}{|c|}{70,33} & \multicolumn{2}{|c|}{58,44} \\
\hline \multicolumn{3}{|c|}{ Nilai THI } & \multicolumn{2}{|c|}{27} & \multicolumn{2}{|c|}{28,64} \\
\hline
\end{tabular}

\section{Analisis RTH terhadap Suhu Udara}

Berdasarkan hasil pengukuran suhu di enam titik lokasi terdapat perbedaan suhu pada keenam lokasi pengukuran, perbedaan antara waktu pengukuran di pagi hari, siang hari, dan sore hari pada suhu udara yang didapatkan, serta terdapat perbedaan pada area pengukuran dengan area di bawah naungan pohon dan area perkerasan.

Hasil pengukuran pada area yang menunjukkan suhu di bawah naungan pohon lebih rendah dibandingkan dengan suhu tanpa naungan pohon. Kondisi naungan pohon suhu rata-rata pada seluruh lokasi pengukuran tidak terlalu berbeda, terutama pada pagi hari (Gambar 39) dengan nilai rata-rata suhunya $\leq 28^{\circ} \mathrm{C}$. Kemudian rata-rata suhu di bawah naungan pohon pada Taman CRM merupakan yang tertinggi pada siang hari jika dibandingkan RTH lainnya, dengan nilai $35,16^{\circ} \mathrm{C}$. Tetapi rata-rata suhu harian taman masjid HSM merupakan yang paling tinggi dibanding semua lokasi, dengan suhu sebesar $30,93^{\circ} \mathrm{C}$. Sedangkan RTH Kantor HSE memiliki suhu rata-rata harian yang paling rendah di antara lokasi studi lainnya dengan suhu sebesar $28,50^{\circ} \mathrm{C}$.

Perubahan suhu udara keenam lokasi menunjukkan meningkat dari pagi hari hingga mencapai puncaknya pada siang hari. Kemudian suhu kembali menurun seiring berkurangnya intensitas sinar matahari pada sore hari (Gambar 39). Kondisi tersebut dikarenakan posisi matahari yang berbeda antara pagi, siang, dan sore hari. Menurut Handoko (1995), suhu udara dapat mencapai nilai maksimum pada saat siang hari (13.00 waktu setempat) dan akan turun kembali hingga mencapai suhu minimum di pagi hari (sekitar pukul 05.00 waktu setempat). 
Hal ini terjadi karena setelah suhu maksimum tercapai maka radiasi yang keluar akan lebih besar dari radiasi yang datang sehingga radiasi yang datang dan digunakan untuk memanaskan suhu udara di sore hari akan menjadi semakin sedikit dibandingkan pada siang hari. Suhu udara di sore hari pada ruang terbuka hijau lebih rendah karena adanya pengaruh dari naungan vegetasi (Handoko et al. 2015). Menurut Maimun (2007), setiap pohon yang ditanam mempunyai kapasitas mendinginkan udara sama dengan rata-rata 5 pendingin udara atau air conditioner, yang dioperasikan 20 jam terus menerus setiap harinya. Setiap 1 ha pepohonan juga mampu menetralkan $\mathrm{CO}_{2}$ yang dikeluarkan 20 kendaraan.

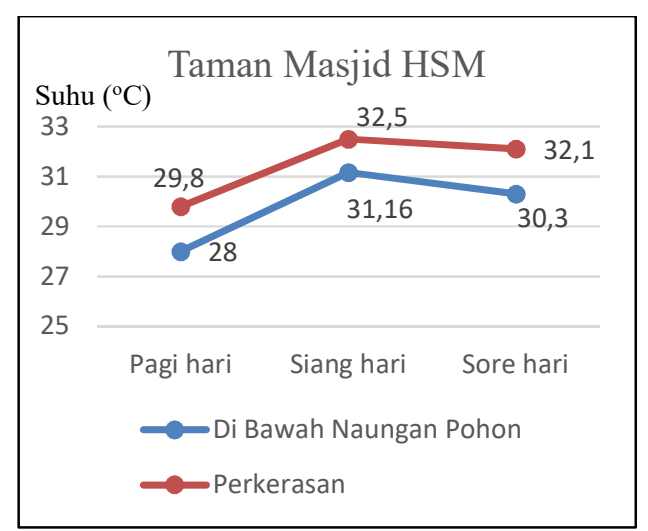

(a)

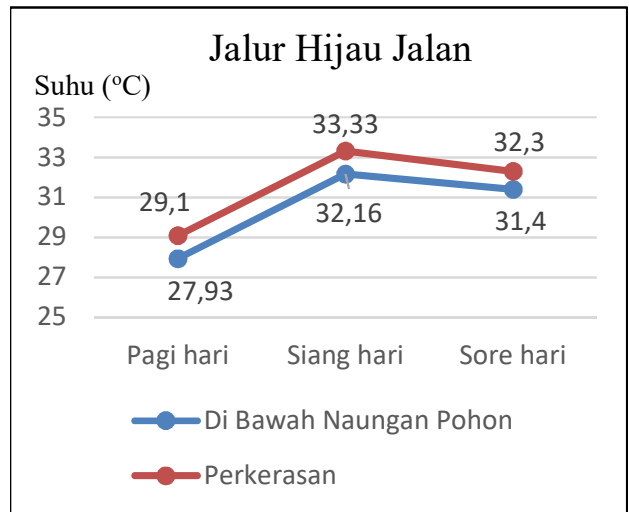

(c)

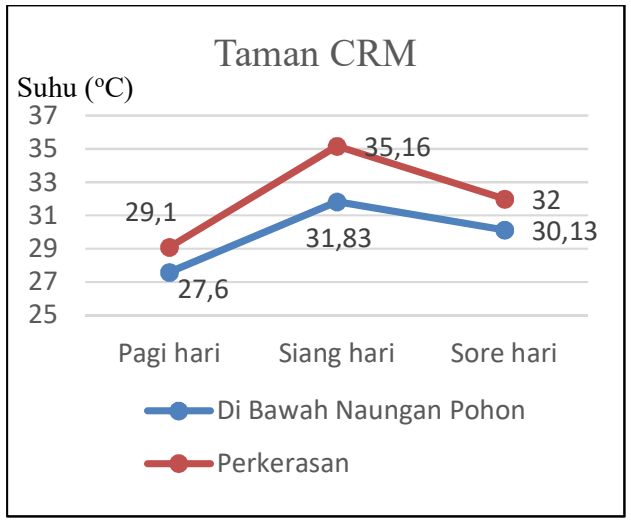

(b)

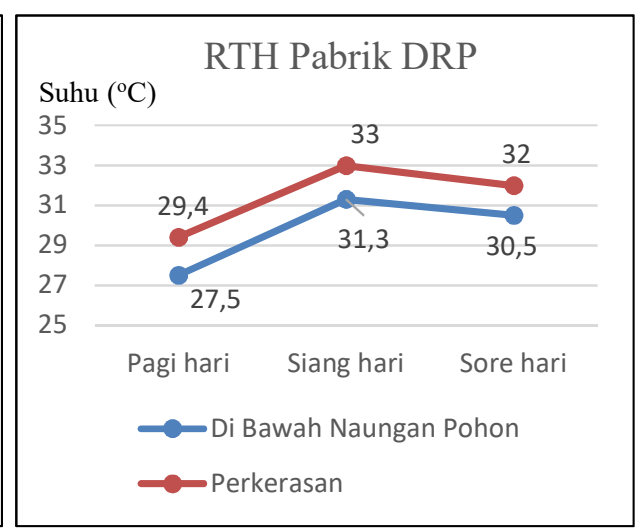

(d)

Gambar 39 Grafik Perubahan Suhu Udara (a. Taman CRM; b. Taman Masjid HSM; c. Jalur Hijau; d. RTH Pabrik DRP) 


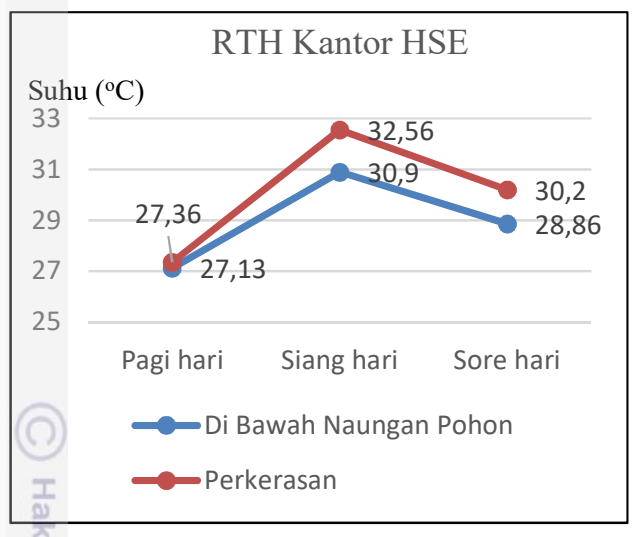

(e)

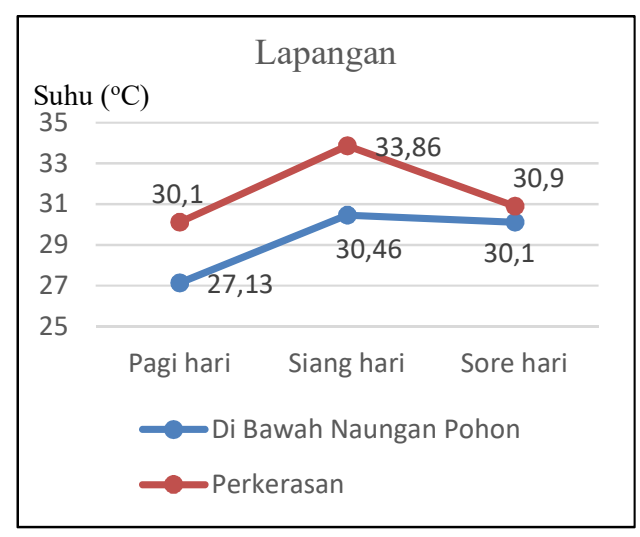

(f)

Gambar 39 (lanjutan) Grafik Perubahan Suhu Udara

(e. RTH Kantor HSE; f. Lapangan)

Suhu maksimum pada keenam lokasi studi, pada umumnya terjadi pada siang hari tanpa naungan pohon dan suhu minimum terjadi pada pagi hari di bawah naungan pohon. Suhu maksimum yaitu $35,16^{\circ} \mathrm{C}$ pada Taman $\mathrm{CRM}$ dan suhu minimum yaitu $27,13^{\circ} \mathrm{C}$ pada pagi hari di RTH Kantor HSE. Radiasi matahari dapat meningkatkan panas benda, seperti elemen yang terdapat pada suatu tapak. Semakin licin dan terang permukaan suatu material, maka akan semakin banyak radiasi matahari yang dipantulkan. Pohon yang memiliki kanopi dan menghasilkan bayangan, mampu mencegah dan menyerap radiasi matahari hingga $90 \%$. Kanopi pohon yang padat berfungsi sebagai penghalang (obstruction) radiasi matahari, sedangkan kanopi yang terbuka berfungsi sebagai penyaring (filtration) radiasi matahari.

Perbedaan suhu antara setiap lokasi pengukuran juga dipengaruh oleh parameter berupa aktivitas pabrik di dekatnya. Pada Taman CRM lokasinya bersebelahan dengan pabrik sehingga suhu udara di luar dipengaruhi oleh aktivitas pabrik yang membutuhkan temperatur sangat panas sekitar $800-1600^{\circ} \mathrm{C}$ dalam pengolahan produk. Otomatis suhu tersebut menyebar ke area taman dan menyebabkan suhu rata-rata taman menjadi sangat tinggi. Berbeda dengan lokasi pengukuran Taman Masjid HSM yang dekat dengan lokasi pabrik namun pada taman tersebut lokasi taman berjarak 20 meter dari pabrik sehingga suhu rata-rata taman tersebut tidak terlalu tinggi seperti di taman CRM.

Pada siang hari suhu di perkerasan taman CRM merupakan yang paling tinggi karena tanaman yang berada pada taman CRM sebagian besar jenis tanaman hias, jenis pohon peneduh cukup banyak tetapi kebanyakan masih berukuran kecil. Berbeda dengan taman masjid HSM yang pada bagian samping masjid dipenuhi tanaman peneduh dengan kerapatan yang tinggi hingga saling bersinggungan, hal tersebut dapat mempengaruhi suhu di perkerasan menjadi menurun. Pada RTH Pabrik DRP suhu juga dipengaruhi oleh aktivitas pabrik. Namun RTH tersebut berjarak sepuluh meter dari pabrik sehingga suhunya lebih rendah dibandingkan taman CRM. Dengan demikian terbukti bahwa jarak berpengaruh terhadap penurunan suhu.

Jalur hijau jalan pada area pengukuran perkerasan maupun di bawah naungan pohon hanya sedikit perbedaanya. Hal tersebut karena vegetasi pada RTH tersebut 
penanamannya tidak terlalu rapat. Perbedaan yang sangat signifikan terdapat di lokasi pengukuran RTH kantor HSE yang letaknya jauh dari pabrik dan dekat dengan perkantoran. Rata-rata suhu di RTH tersebut merupakan yang paling rendah dibandingkan dengan lokasi pengukuran lainnya, karena lokasinya yang cukup jauh dari pabrik. Keberadaan vegetasi yang melimpah dalam RTH tersebut membantu terciptanya suhu lingkungan yang lebih baik akibat adanya proses evaporasi dan transpirasi yang dilakukan oleh vegetasi di dalam RTH. Kondisi ini dapat memberikan efek yang baik bagi kondisi lingkungan sekitarnya baik dalam menjamin sistem hidrologi maupun bagi kesehatan udara di lingkungan sekitar (Handoko et al. 2015).

\section{Analisis RTH terhadap Kelembaban Udara}

Berdasarkan hasil pengukuran kelembaban pada enam area ukur di pagi hari, siang hari, dan sore hari didapatkan nilai kelembaban sebesar 50,66 \% sampai dengan 81,33 \% di Taman CRM, 53 \% sampai dengan 80,33 \% di Taman Masjid HSM, 52,66 \% sampai dengan $78 \%$ di Jalur Hijau, 51,67 \% sampai dengan $82 \%$ di RTH Kantor HSE, 53,33 \% sampai dengan 79,67 \% di RTH Pabrik DRP, dan $45,67 \%$ sampai dengan $74,33 \%$ di Lapangan. Nilai rata-rata hasil pengukuran kelembaban dari tiga lokasi penelitian disajikan pada Gambar 40.

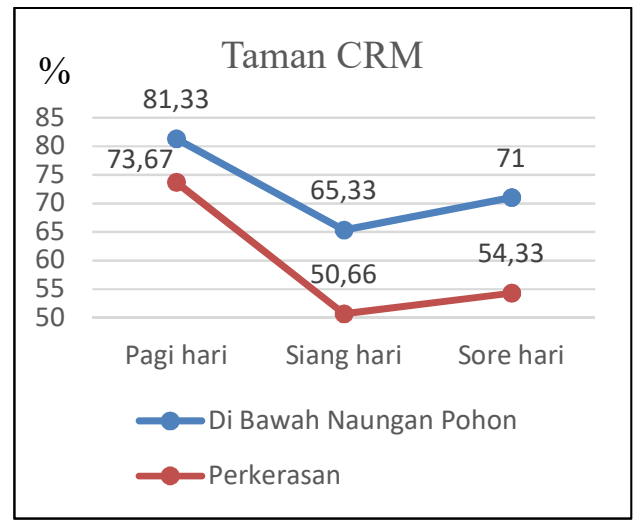

(a)

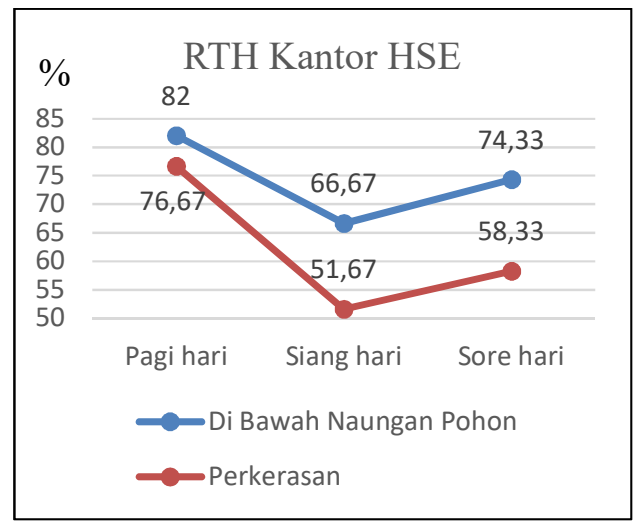

(c)

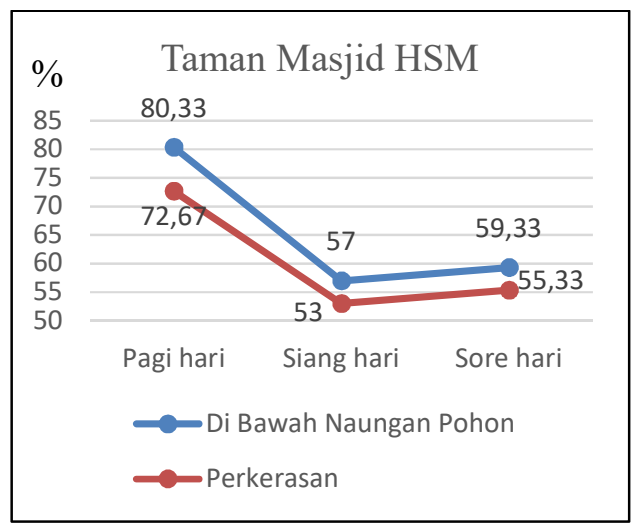

(b)

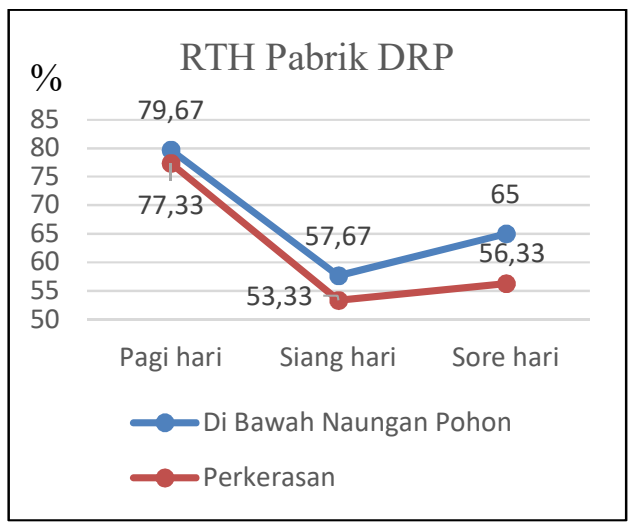

(d)

Gambar 40 Grafik Perubahan Kelembaban Udara

(a. Taman CRM; b. Taman Masjid HSM; c. RTH Kantor HSE; d. RTH Pabrik DRP) 


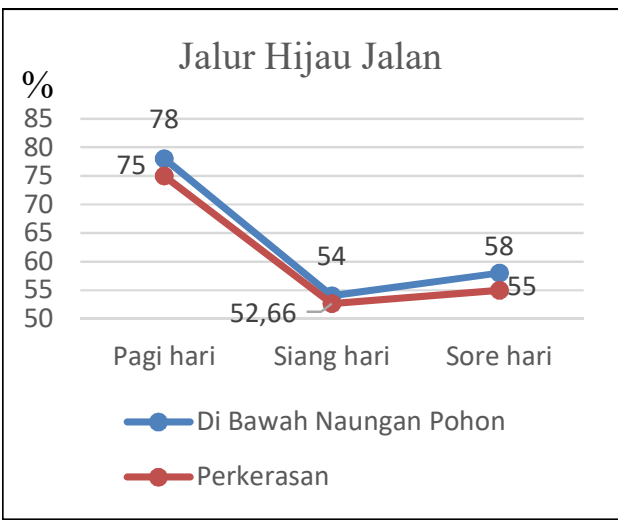

(e)

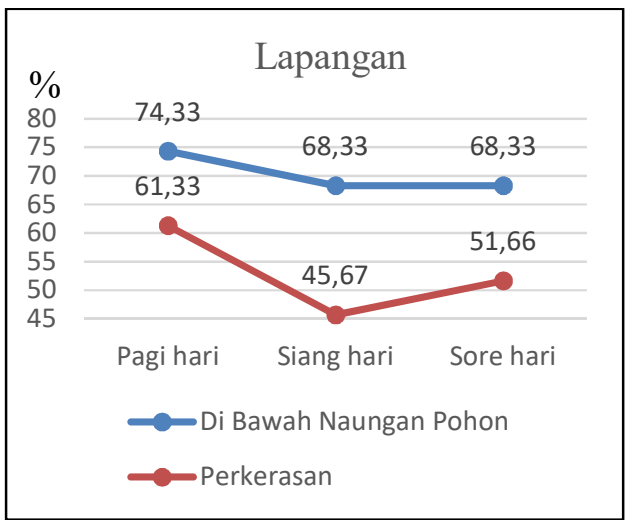

(f)

Gambar 40 (lanjutan) Grafik Perubahan Kelembaban Udara (a. Jalur Hijau Jalan; e. Lapangan)

Gambar 40 menunjukan bahwa nilai kelembaban rata-rata paling tinggi berada pada area Taman CRM di bawah naungan pohon saat pengukuran pagi hari. Nilai rata-rata kelembaban pada area di bawah naungan pohon saat pagi hari sebesar $81,33 \%$ pada Taman CRM, 80,33 \% pada Taman Masjid HSM, $78 \%$ pada Jalur Hijau, 79,67 \% pada RTH Pabrik DRP, dan 74,33 \% pada Lapangan. Taman CRM memiliki kelembaban yang tinggi karena lokasi ini pada pagi hari dilakukan pengukuran kelembaban udara saat aktivitas pabrik belum dimulai.

Nilai kelembaban rata-rata paling tinggi berada pada area Lapangan di bawah naungan pohon saat pengukuran siang hari. Nilai rata-rata kelembaban pada area di bawah naungan pohon saat siang hari sebesar 65,33\% pada Taman CRM, $57 \%$ pada Taman Masjid HSM, 54 \% pada Jalur Hijau Jalan, 57,67\% pada RTH Pabrik DRP 57,67 \% pada RTH HSE, dan 68,33 \% pada Lapangan. Hal ini disebabkan oleh lokasi Lapangan tidak terlalu dekat dengan pabrik dan adanya jumlah vegetasi pohon di pinggir lapangan yang cukup banyak dan rapat. Menurut Asiani (2007), lokasi dengan jumlah vegetasi yang lebih banyak memiliki kelembaban udara yang lebih tinggi, sedangkan lokasi dengan vegetasi yang lebih sedikit memiliki kelembaban udara yang lebih rendah.

Menurut Laurie (1985), kelembaban udara ideal bagi manusia adalah 40-75\%. Dari hasil pengukuran, kelembaban udara pada semua titik pengamatan di pagi hari lebih besar dari $75 \%$. Kelembaban udara yang terlalu tinggi menggangu kenyamanan pengguna. Dalam penelitian Lestari dan Kencana (2008), kelembaban udara yang baik untuk tanaman adalah antara 60-90\% untuk 50 tanaman hutan hujan tropis. Kelembaban udara sangat berpengaruh dalam proses penguapan tanaman atau transpirasi. Kelembaban yang tinggi akan menggangu keseimbangan unsur air dan cahaya yang dibutuhkan tanaman dalam bertumbuh. Menurut Carpenter et al. (1975) dan Grey et al. (1978), tanaman berdaun jarum/berdaun kasar, berpola percabangan horizontal, dan bertekstur batang kasar mampu mengontrol kelembaban udara di suatu wilayah. 


\section{Analisis RTH Terhadap Kenyamanan Manusia}

Indeks kenyamanan manusia yang ditentukan di penelitian ini diukur berdasarkan thermal comfort dengan metode Temperature Humidity Index (THI) yang menerapkan suhu udara dan kelembaban relatif. Nilai indeks yang dihitung berdasarkan persamaan Nieuwolt menghasilkan tiga kategori yaitu nyaman, cukup nyaman, dan tidak nyaman. Kategori Nyaman yaitu $21 \leq \mathrm{THI} \leq 24$, Cukup nyaman yaitu $24<\mathrm{THI} \leq 26$, dan Tidak nyaman yaitu $\mathrm{THI}>26$. Berikut adalah hasil perhitungan THI (Gambar 41).

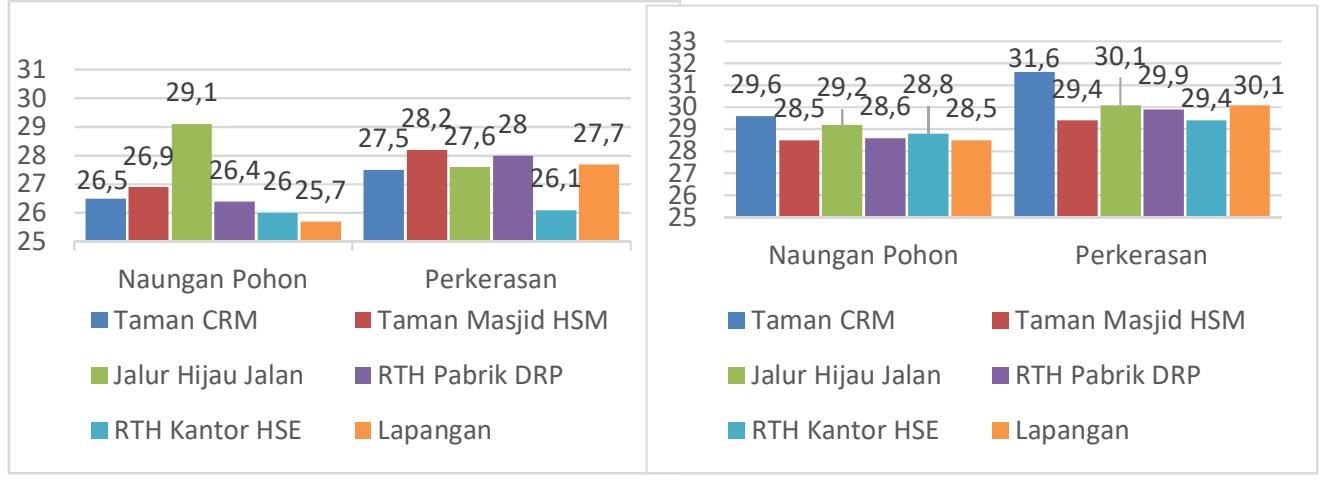

(a)

(b)

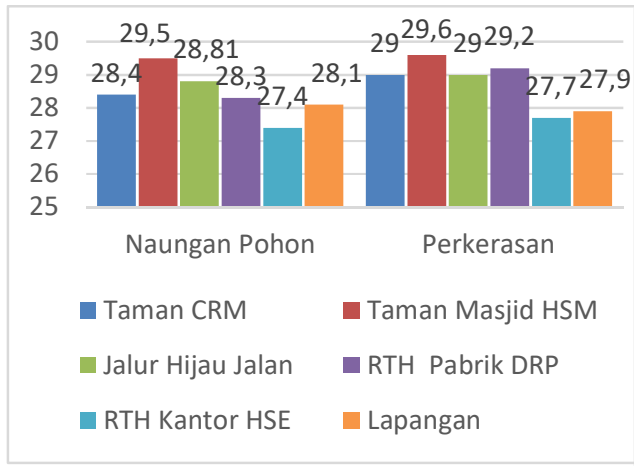

(c)

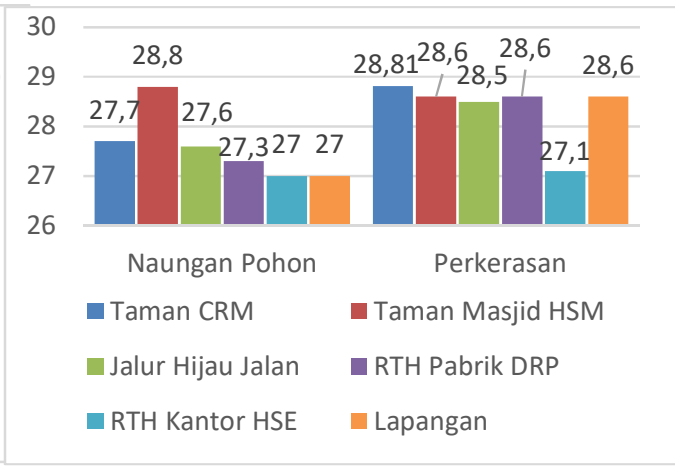

(d)

Gambar 41 Hasil Perhitungan Temperatur Humidity Index (THI)

(a. Pagi Hari; b. Siang Hari; c. Sore Hari; d. Harian) 


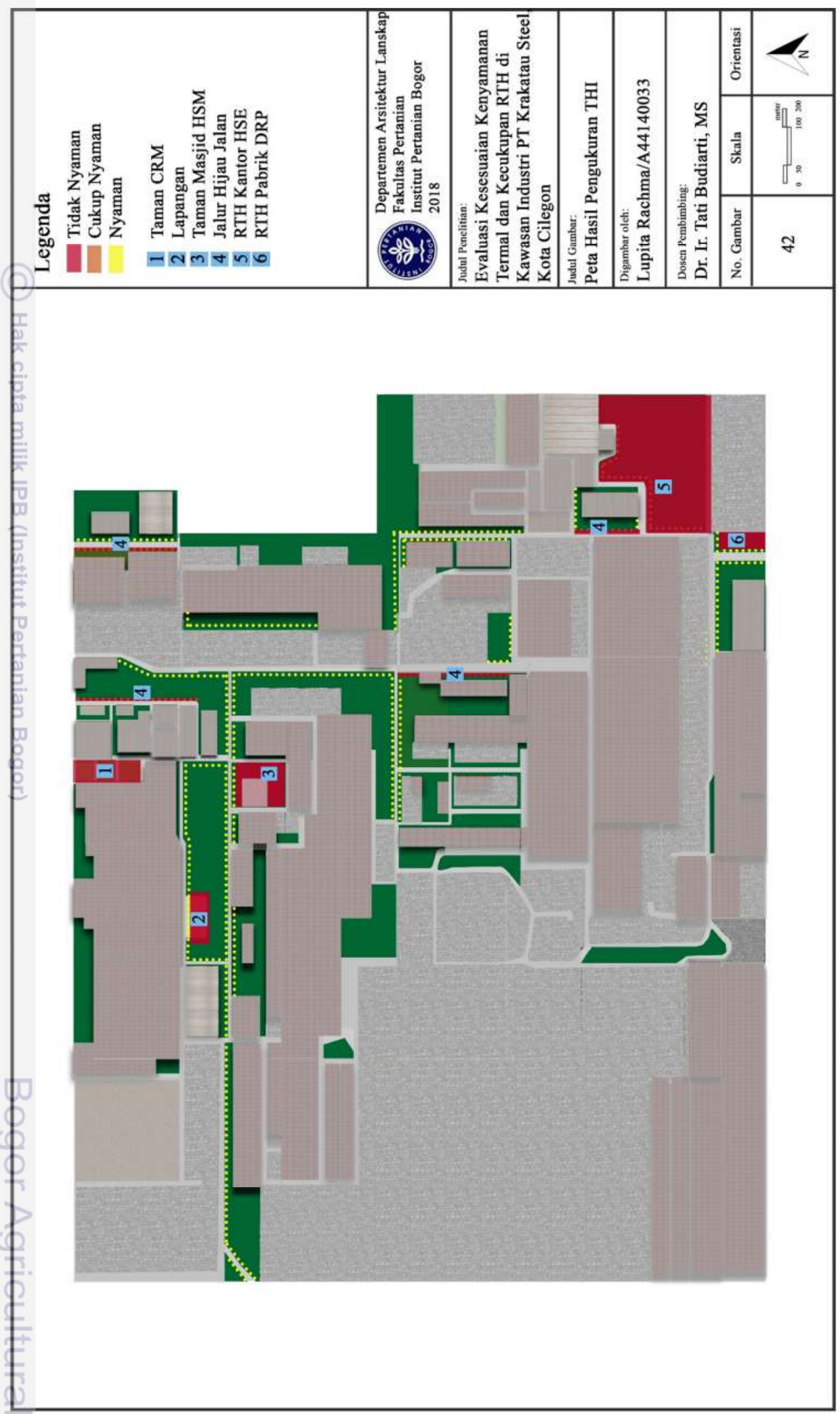

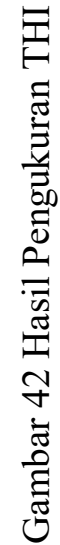


Dari hasil analisis, diperoleh hasil bahwa seluruh nilai Temperature Humidity Index (THI) lebih besar dari 26 (Gambar 41). Hal ini berarti pada seluruh lokasi studi yaitu Taman CRM, Taman Masjid HSM, RTH Kantor HSE, RTH Pabrik DRP, Jalur Hijau Jalan, Lapangan baik di bawah naungan pohon atau pun tanpa naungan pohon kurang memberikan kenyamanan termal bagi manusia. Pagi hari di sebagian besar lokasi pengamatan baik di area ukur di bawah naungan pohon maupun perkerasan termasuk ke dalam kategori tidak nyaman, namun pada area ukur RTH Kantor HSE dan Lapangan memiliki nilai terendah karena nilai THI harian sebesar 27. Hal tersebut dapat disebabkan vegetasi di sekeliling lapangan yang cukup rapat sehingga dapat meningkatkan kenyamanan. Sedangkan di area ukur RTH Kantor HSE tidak terdapat pabrik, sedangkan THI di area ukur lainnya dipengaruhi oleh aktivitas pabrik yang menghasilkan panas dan dapat mempengaruhi lingkungan sekitarnya.

Kenyamanan pada siang hari menunjukkan nilai pada rentang tidak nyaman pada setiap area ukur. Area di bawah naungan pohon nilai THI $\geq 28$ dan nilai THI di perkerasan THI $>29$. Area dengan naungan pohon lebih memberikan kenyamanan dibandingkan dengan kawasan perkerasan yang tidak ternaungi. Suhu udara di siang hari meningkat disebabkan radiasi matahari yang meningkat menyebabkan kenaikan suhu udara serta penurunan kelembaban udara (RH). Intensitas aktivitas produksi di pabrik juga semakin meningkat jika dibandingkan dengan pagi hari. Hal tersebut dapat memperburuk kondisi kenyamanan pada semua lokasi pengamatan.

Pada sore hari seluruh lokasi pengamatan termasuk dalam kategori tidak nyaman. Suhu udara di sore hari akan menjadi lebih rendah dibandingkan dengan siang hari sehingga keadaan suhu pada sore hari akan lebih baik dibandingkan pada siang hari. Namun karena aktivitas pabrik di siang hari terus intensif hingga sore hari, maka nilai THI pada sore hari tidak terlalu berubah. Pada sore hari pada area ukur taman masjid HSM memiliki nilai THI tertinggi yakni mencapai 29,5. Hal ini disebabkan oleh arah angin dari utara ke selatan, angin tersebut membawa panas dari setiap pabrik CRM yang berlokasi di sebelah utara menuju ke arah taman masjid HSM.

Namun dalam penelitian ini terjadi sebuah anomali, lazimnya di bawah naungan pohon memberikan kenyamanan yang lebih baik dibandingkan di perkerasan, namun hal tersebut tidak terjadi di Taman Masjid HSM. Pada taman tersebut, nilai THI di bawah naungan lebih tinggi dibandingkan di perkerasan. Hal tersebut dikarenakan kelembaban pada lokasi pengukuran di bawah naungan pohon cukup tinggi dibandingkan di area perkerasan, sedangkan suhunya tidak terlalu berbeda. Menurut Rahmawati (2014), kelembaban lebih mudah berubah dibandingkan suhu sehingga dapat mempengaruhi hasil kenyamanan termal yang diperoleh. Pada taman Masjid HSM, pohon-pohon ditanam secara rapat dan tajuknya saling bersinggungan sehingga dapat mengurangi radiasi matahari yang sampai ke permukaan tanah sehingga mengurangi penguapan serta mempercepat peningkatkan kelembaban dibandingkan di area perkerasan.

Penelitian ini menunjukkan hasil yang sama yaitu pada area yang pohonnya yang ditanam secara berkelompok akan menghasilkan suhu udara yang lebih rendah, sehingga tingkat kenyamanan yang diperoleh pun akan menjadi lebih baik. Contohnya pada lapangan dan RTH Kantor HSE yang memiliki nilai THI harian cukup nyaman yaitu ditanam secara rapat dan berkelompok, bentuk tajuk pohon menyebar yaitu pohon mahoni daun lebar (Swietenia macrophyla), dan ki hujan 
(Samanea saman). Nilai THI dengan nilai harian tertinggi yaitu di RTH Pabrik DRP, dengan tajuk vegetasi yang tidak menaungi yaitu Bambu Kuning (Bambusa vulgaris). Hasil penilaian pada indeks kenyamanan harian memperlihatkan bahwa seluruh kawasan memiliki kategori tidak nyaman. Tajuk pepohonan di RTH dapat mengurangi radiasi matahari di RTH sehingga nilai suhu udara di kawasan RTH akan lebih rendah dibandingkan dengan kawasan luar RTH. Semakin sedikitnya radiasi yang diterima pada kawasan RTH akan memungkinkan terjadinya penurunan suhu udara dan peningkatan kelembaban relatif di sekitar sehingga dapat memperbaiki kenyamanan termal manusia. Panas yang lebih tinggi di luar RTH ditambah dengan suhu tinggi dari pabrik akan menyebabkan kenyamanan termal yang lebih buruk dibandingkan di dalam RTH. Kategori kenyamanan pada siang hari menunjukkan nilai pada rentang tidak nyaman untuk area perkerasan.

Kenyamanan udara suatu lokasi dipengaruhi besarnya suhu udara, kelembaban udara, kecepatan angin, dan radiasi matahari. Namun indeks kenyamanan pada penelitian ini dilihat dari dua faktor yakni suhu dan kelembaban udara. Tingkat kenyamanan termal merupakan hasil penilaian yang hasilnya berupa serangkaian kondisi dengan semakin tinggi suhu udara dan rendah kelembaban udara menyebabkan nilai THI menjadi tinggi dan kenyamanan berkurang, begitu pula sebaliknya. Secara keseluruhan dapat dilihat bahwa indeks kenyamanan di luar RTH (perkerasan) memiliki nilai yang selalu lebih tinggi dibandingkan di dalam RTH (naungan pohon). Suhu udara yang lebih panas pada kawasan luar RTH menjadi faktor yang dapat memberikan kenyamanan yang lebih buruk dibandingkan dengan kawasan yang memiliki RTH pada siang hari. Hal tersebut terjadi karena tidak adanya penghalang sinar matahari pada kawasan luar RTH, sehingga sinar matahari langsung diterima oleh permukaan.

\section{Analisis Persepsi dan Preferensi Karyawan}

Persepsi dan preferensi karyawan didapatkan dari hasil penyebaran kuesioner. Responden berjumlah 30 karyawan tetap PT KS yang berasal dari dua pabrik yaitu Hot Strip Mill (HSM), dan Cold Rolling Mill (CRM). Masing-masing pabrik dipilih 15 orang karyawan secara acak dengan latar belakang usia serta jabatan yang berbeda. Waktu pemberian kuesioner kurang lebih satu jam, dan dilakukan pada pagi hari sebelum karyawan mulai bekerja. Hasil penilaian kuesioner ini kemudian dianalisis, analisis yang dilakukan mencakup karakteristik karyawan, persepsi karyawan terhadap RTH, aktivitas karyawan di RTH, serta preferensi karyawan terhadap kawasan industri maupun RTH.

\section{Karakteristik karyawan}

Dari hasil sebaran kuesioner yang disebarkan, terdapat beberapa karakteristik karyawan yang menjadi responden. Responden terpilih adalah 50\% karyawan yang baru bekerja 1-20 tahun, sedangkan 50\% lainnya yaitu karyawan yang sudah bekerja di atas 20 tahun (Gambar 43). Karyawan yang sudah bekerja lebih dari 20 tahun rata-rata memiliki jabatan senior engineer. Semua responden berjenis kelamin laki-laki dengan karakteristik usia 20 hingga 55 tahun. Responden yang dipilih merupakan karyawan yang bekerja di kantor, karena karyawan yang bekerja di lapang atau pabrik tidak memungkinkan melakukan pengisian kuesioner. 


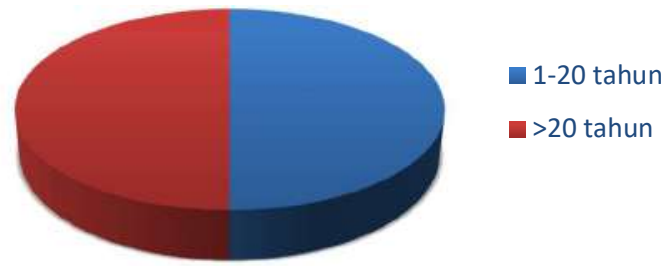

Gambar 43 Lama Bekerja Karyawan yang Menjadi Responden

\section{Persepsi karyawan terhadap Kawasan Industri}

Persepsi karyawan terhadap hubungan antara kegiatan industri PT KS dan lingkungan tidak bervariasi. Seluruh responden menilai bahwa PT KS dapat menjaga lingkungan di sekitarnya melalui keberadaan daerah penyangga di setiap pabrik. Daerah penyangga ini terdiri dari pepohonan besar yang dapat menyaring dan mengurangi debu di sekitar kawasan industri.

Ketika berada di kawasan industri, terdapat beberapa kondisi kawasan industri yaitu didominasi banyak bangunan, didominasi pepohonan dan tanaman lainnya, maupun didominasi bangunan tetapi ada beberapa tanaman di sekitarnya. $10 \%$ responden menilai bahwa kawasan industri PT KS merupakan kawasan yg memiliki banyak bangunan dan lingkungan yang cenderung panas, 20\% responden menilai bahwa kawasan industri PT KS merupakan kawasan yg memiliki banyak pepohonan dan tanaman lainnya sehingga terasa sejuk dan nyaman, 70\% responden menilai bahwa kawasan industri PT KS merupakan kawasan yg memiliki banyak bangunan tetapi ada beberapa tanaman di sekitarnya (Gambar 44).

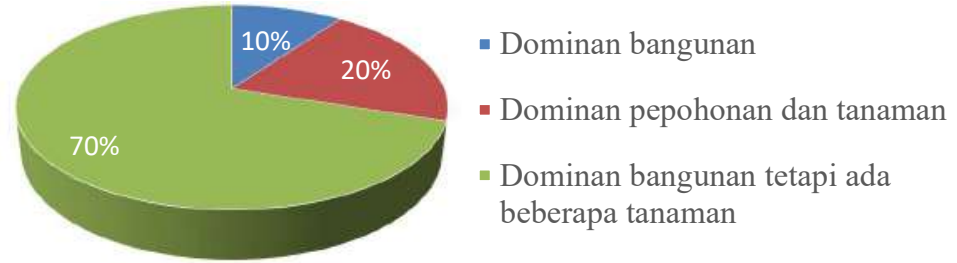

Gambar 44 Persepsi Karyawan terhadap Kondisi Kawasan Industri

\section{Persepsi karyawan terhadap ruang terbuka hijau (RTH)}

Selain melakukan penilaian terhadap kondisi lokasi industri juga dilakukan penilaian terhadap RTH. Sebagian besar karyawan PT KS umumnya sudah mengetahui definisi Ruang Terbuka Hijau (RTH) secara sederhana yaitu ruang atau lahan yang didalamnya diiisi oleh tanaman baik rumput, semak, maupun pohon. Meskipun beberapa diantara karyawan kurang mengetahui istilah RTH tetapi hanya mengetahui tentang sebidang lahan yang ditanami jenis-jenis tanaman. Berikut pengetahuan karyawan mengenai RTH (Gambar 45). 


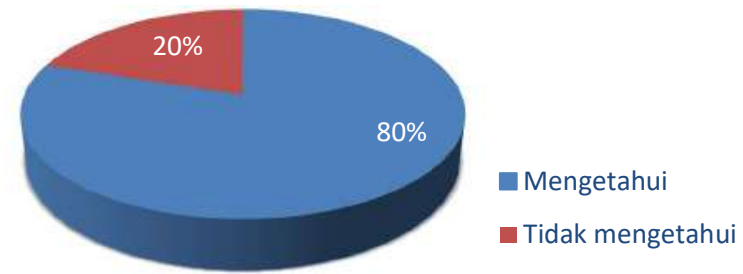

Gambar 45 Pengetahuan Karyawan Mengenai RTH

Karyawan pada umumnya berpendapat tentang pentingnya RTH yaitu menghasilkan suasana sejuk, menyaring polusi di kawasan, menambah kenyamanan, menurunkan suhu udara, menyegarkan pikiran, dan memberi keteduhan. Menurut karyawan, kondisi lingkungan yang banyak tanamannya merupakan lingkungan yang sejuk, bersih, dan sehat. Tidak ada karyawan yang menganggap bahwa lingkungan yang didominasi tanaman merupakan lingkungan yang panas, kotor, dan lembab.

Kondisi lingkungan yang sejuk, sehat, dan bersih mampu meningkatkan kenyamanan. Tanaman merupakan salah satu faktor yang dapat mempengaruhi kenyamanan. Dengan keberadaan tanaman, suhu udara menjadi turun, udara segar dapat dihasilkan, dan tanaman dapat menjadi penaung bagi manusia. Hal ini didukung dengan persepsi semua responden yang merasa lebih nyaman ketika berada di tempat yang banyak terdapat pohon maupun tanaman lainnya.

Seluruh responden merasa nyaman berada pada RTH, karena kenyamanan tersebut dipengaruhi keberadaan tanaman, yaitu pohon, semak, dan rumput terutama tanaman jenis pohon dianggap memberi kenyamanan karena berfungsi sebagai peneduh dan penyaring debu emisi dari pabrik. Begitu juga untuk kondisi tidak nyaman suatu tempat yang dipengaruhi oleh beberapa faktor. Faktor yang paling berpengaruh di kawasan industri tersebut adalah keterbatasan fasilitas RTH, meskipun terdapat beberapa karyawan merasa kurang nyaman karena terbatasnya tanaman di sekitar kawasan. Sebanyak 67\% karyawan yang merasa tidak nyaman karena terbatasnya fasilitas pada RTH dan sisanya 13\% merasa tidak nyaman karena terbatasnya tanaman di lingkungannya (Gambar 46).

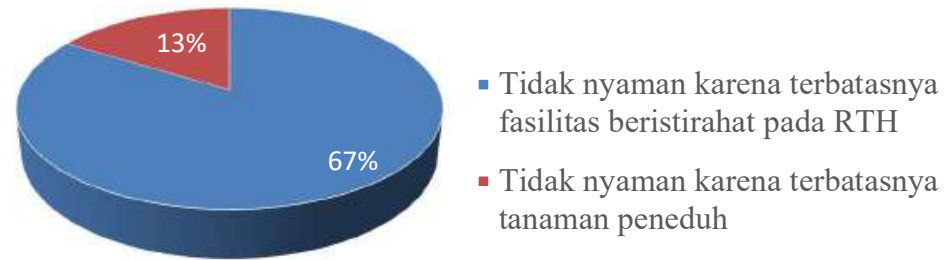

Gambar 46 Persepsi Karyawan terhadap Penyebab Ketidaknyamanan

Penyebab karyawan merasa tidak nyaman jika fasilitas RTH terbatas adalah dikarenakan karyawan merasa RTH tidak dapat dipakai beristirahat. Sedangkan alasan karyawan merasa tidak nyaman karena terbatasnya tanaman didasari oleh suhu udara di luar ruangan yang sangat panas karena suhu udara kota Cilegon yang tinggi ditambah dengan panas yang dihasilkan oleh aktivitas pabrik serta kondisi banyak debu yang terbawa angin membuat RTH menjadi tidak nyaman jika tidak 
terdapat banyak tanaman. Hal tersebut menyebabkan karyawan lebih merasa nyaman berada di ruangan dengan air conditioner. Karyawan jarang menghabiskan waktu di luar gedung pabrik atau kantor dikarenakan waktu istirahat yang sempit, sehingga waktu istirahat dihabiskan di dalam ruangan atau bangunan yang dirasa lebih nyaman dibanding berada di luar ruangan.

RTH yang dijadikan lokasi pengukuran suhu dan kelembaban di kawasan industri terdiri dari enam jenis RTH yaitu Taman CRM, Taman Masjid HSM, Lapangan, Jalur Hijau Jalan, RTH Pabrik DRP dan RTH kantor HSE. Selain melalui pengukuran, kenyamanan juga perlu ditinjau dari persepsi pengguna RTH tersebut untuk dilihat apakah ada perbedaan antara hasil perhitungan Thermal Humidity Index (THI) dengan yang dirasakan oleh pengguna.

Kayawan sebagian besar berpendapat bahwa RTH yang ada dapat memberikan kenyamanan (Gambar 47). Sebanyak $87 \%$ karyawan menganggap Taman CRM dapat memberikan kenyamanan dan $13 \%$ karyawan berpendapat bahwa Taman CRM tidak dapat memberikan kenyamanan karena suhu cukup panas, kurangnya pohon peneduh serta lokasinya terlalu dekat dengan pabrik. Sedangkan pada Taman Masjid HSM $90 \%$ menganggap taman ini dapat memberikan kenyamanan karena dapat menciptakan suasana yang teduh, namun $10 \%$ karyawan menganggap Taman masjid HSM tidak nyaman karena penanaman pohon pada bagian samping masjid yang terlalu rapat sehingga suasana menjadi lembab.

Seluruh karyawan berpendapat bahwa jalur hijau jalan sudah memberikan kenyamanan karena dapat memperindah tampilan jalan dan memberi keteduhan kepada pejalan kaki. Sebanyak 87 \% karyawan menganggap RTH Pabrik DRP dapat memberikan kenyamanan dan $13 \%$ karyawan berpendapat bahwa RTH Pabrik DRP tidak dapat memberikan kenyamanan karena tidak terdapat fasilitas untuk beristirahat. Hal tersebut berbanding terbalik dengan RTH Kantor HSE dengan fasilitas untuk beristirahat dan lokasinya yang jauh dari pabrik dianggap dapat memberikan kenyamanan bagi seluruh responden. Kemudian pada RTH Lapangan, sebanyak $93 \%$ karyawan merasa nyaman, hanya 7\% yang merasa tidak nyaman karena kondisi rumput yang kurang baik.

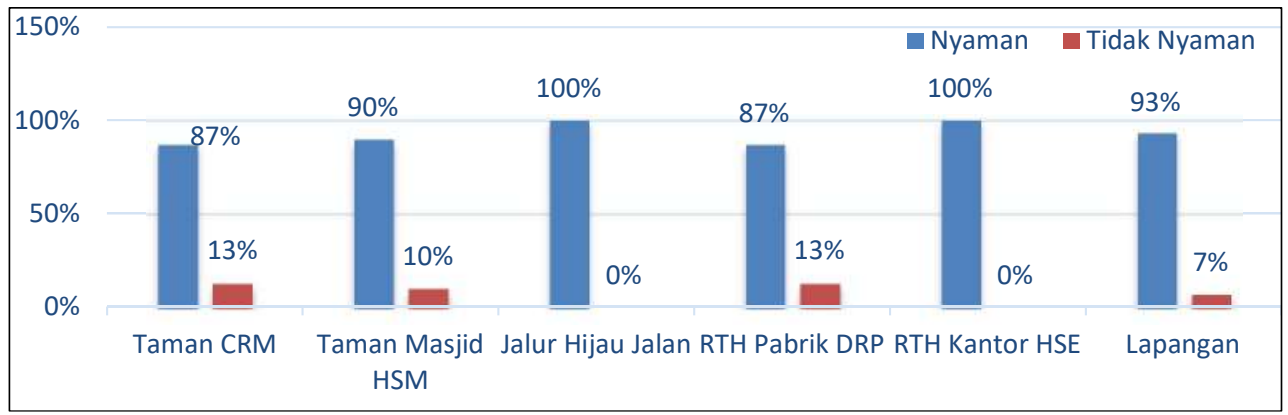

Gambar 47 Persepsi Karyawan terhadap Kenyamanan pada RTH

Meskipun sangat penting dan memberikan kenyamanan, kondisi RTH saat ini kurang baik karena tidak semua RTH dapat berfungsi maksimal dan beberapa diantaranya kurang terawat. Karyawan berpendapat bahwa RTH di PT KS sudah fungsional, akan tetapi terdapat karyawan yang berpendapat bahwa RTH kurang dirasakan manfaatnya terhadap lingkungan (Gambar 48). 


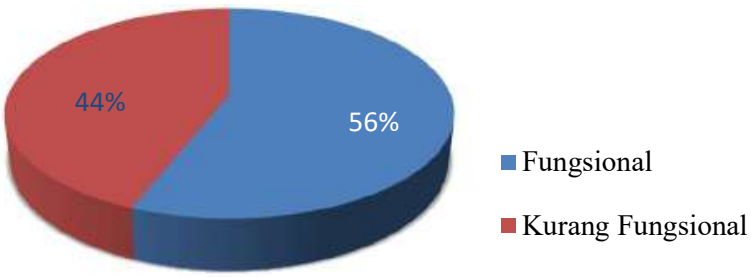

$\begin{array}{cl}\text { Gambar } 48 & \text { Persepsi Karyawan terhadap Hubungan } \\ & \text { RTH dan Lingkungan }\end{array}$

Sebanyak 56\% responden berpendapat bahwa RTH di kawasan industri sudah cukup baik, dengan fungsinya sebagai peneduh serta penyerap debu emisi, tetapi 44\% responden berpendapat bahwa RTH masih kurang baik karena kurangnya RTH yang berfungsi sebagai tempat beristirahat bagi karyawan (Gambar 49). Karyawan juga menilai bahwa jika kawasan industri hanya didominasi oleh bangunan serta perkerasan lainnya akan membuat lingkungan menjadi sangat panas dan tidak nyaman. Kondisi lingkungan yang monoton dinilai dapat menyebabkan kejenuhan dalam melakukan pekerjaan.

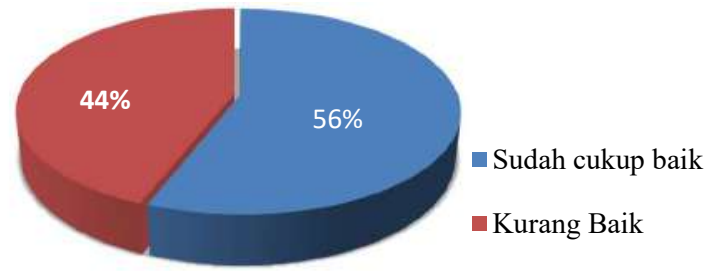

Gambar 49 Persepsi Karyawan terhadap Kondisi RTH

\section{Aktivitas Karyawan di Ruang Terbuka Hijau}

Selain melakukan pekerjaan, sebagian karyawan menghabiskan waktu di ruang terbuka hijau dan sebagian lagi tidak melakukannya.. Sebanyak 23\% karyawan jarang melakukan aktivitas di ruang terbuka hijau dan $77 \%$ karyawan sering melakukan aktivitas di ruang terbuka hijau (Gambar 50).

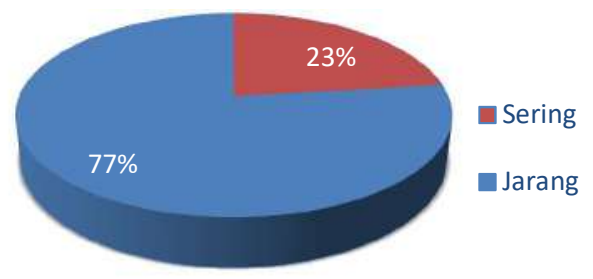

\section{Gambar 50 Intensitas Aktivitas Karyawan pada RTH}

Beberapa responden sering melakukan aktivitas pada RTH saat istirahat di siang hari. Aktivitas yang sering dilakukan yaitu sekedar menghirup udara bersih, merokok, jalan-jalan, ataupun mobilitas pekerjaan seperti mengambil data yang dibutuhkan yang berada pabrik lain yang mengharuskan karyawan melintasi RTH antar pabrik. Sedangkan sebagian karyawan tidak sering menghabiskan waktu di 
RTH karena lingkungan RTH yang kurang perawatan sehingga terlihat kotor serta fasilitas di RTH yang belum memadai, seperti tempat beristirahat bagi karyawan.

Banyak sekali aktivitas yang dapat dilakukan karyawan di RTH, termasuk pada saat pagi hari, sore hari, maupun jam istirahat. Ketika jam istirahat, karyawan bisa memilih tetap di dalam ruangan, duduk-duduk di bawah pohon, makan dan minum di kantin, dan sebagainya. Berikut pilihan aktivitas karyawan saat jam istirahat (Gambar 51).

Sebanyak 16\% karyawan lebih memilih tetap di ruangan, 50\% karyawan menghabiskan waktu di kantin, 20\% karyawan memilih duduk di bawah pohon, 14\% memilih lainnya. Karyawan yang memilih tetap di ruangan melakukan aktivitas seperti berkumpul karyawan lain, sholat, dan makan. Karyawan yang lebih memilih makan di kantin menuturkan udara di kantin lebih segar karena dekat pepohonan. Karyawan yang memilih menghabiskan waktu istirahat duduk di bawah pohon biasanya ingin menghirup udara segar sambil merokok. Sedangkan yang memilih lainnya yaitu karyawan yang memilih melakukan lebih dari dua kegiatan, seperti makan di kantin dan sholat di masjid, serta karyawan yang menghabiskan waktu istirahatnya di masjid.

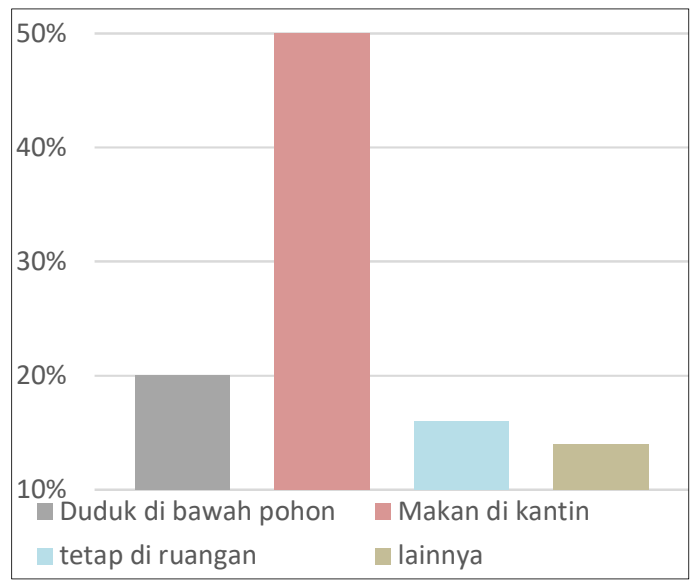

Gambar 51 Aktivitas Karyawan pada Jam Istirahat

RTH sebagai bagian dari ruang terbuka seharusnya dapat menjadi salah satu pilihan karyawan untuk beristirahat. RTH di PT KS sudah cukup banyak tetapi tidak ada yang mengakomodasi fasilitas bagi istirahat karyawan. Menurut 30\% karyawan fasilitas yang terdapat di RTH sudah cukup, tetapi 70\% karyawan merasa fasilitas yang terdapat di RTH belum cukup (Gambar 52). Karyawan berpendapat ingin menghabiskan waktu di RTH jika fasilitasnya memadai, seperti bench dan gazebo.

Sebagian besar RTH belum bisa digunakan menurut karyawan. Hal tersebut didasari oleh beberapa faktor, seperti pohon peneduh yang belum cukup. Pohon peneduh tentu saja mempengaruhi kenyamanan di RTH, karena dapat menurunkan suhu di kawasan industri yang sangat panas. Sebanyak 76\% karyawan merasa jumlah pohon peneduh belum cukup untuk beristirahat di luar ruangan sedangkan 24\% karyawan merasa jumlah pohon peneduh sudah cukup (Gambar 53).

Penataan tanaman terutama pohon di kawasan industri meningkatkan nilai estetika kawasan industri yang dapat berpengaruh positif bagi kinerja karyawan. Menurut $70 \%$ karyawan penataan pohon peneduh dapat mengurangi kejenuhan 
dalam bekerja, sedangkan 30\% lainnya tidak menganggap penataan pohon peneduh dapat mengurangi kejenuhan dalam bekerja (Gambar 54). Sebanyak 30\% karyawan tersebut menilai bahwa yang dapat mengurangi kejenuhan kerja adalah penambahan waktu istirahat.

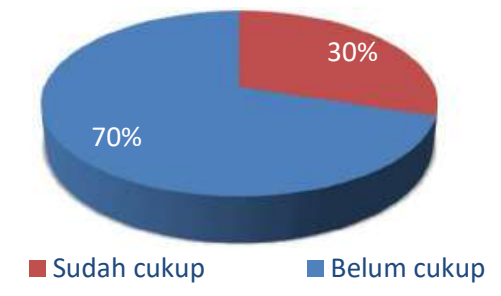

Gambar 52 Persepsi Terhadap

Fasilitas pada RTH

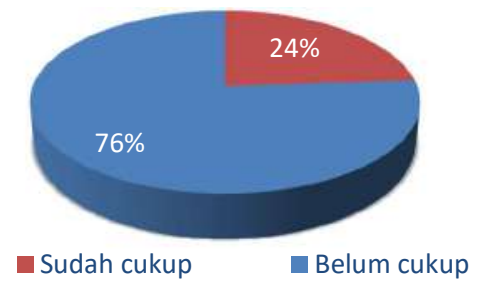

Gambar 53 Persepsi terhadap Jumlah Pohon Peneduh

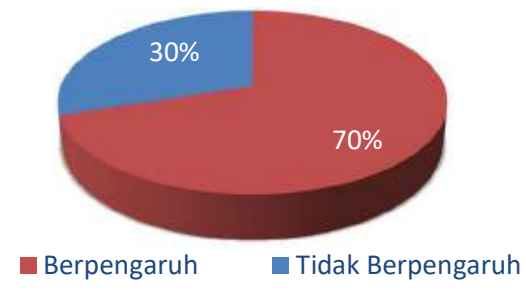

Gambar 54 Persepsi Pengaruh Penataan Pohon dalam Mengurangi Kejenuhan

Fasilitas yang dapat menunjang kegiatan karyawan di dalam ruang terbuka hijau menjadi sangat penting, karena dengan adanya fasilitas tersebut karyawan dapat menggunakan ruang terbuka hijau dengan lebih maksimal. Fasilitas yang dapat ditambahkan antara lain taman kecil, saung, gazebo, lapangan olahraga, bench, dan lainnya. Sebanyak 40\% karyawan memilih taman kecil, 34\% memilih saung/gazebo, 23\% memilih lapangan olahraga, sisanya 3\% memberikan pilihan lain yaitu jogging track (Gambar 55).

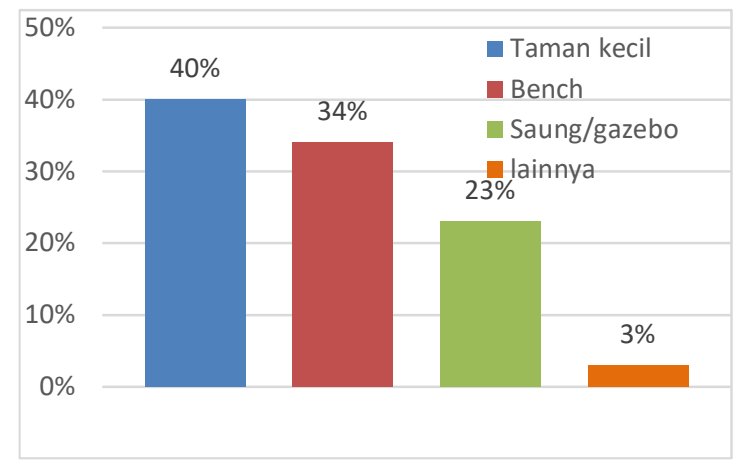

Gambar 55 Preferensi Fasilitas yang Perlu ditambahkan 
Lokasi beristirahat di kawasan industri harus memiliki kriteria tertentu agar dapat memberikan kenyamanan bagi pengguna, yaitu karyawan itu sendiri, seperti area yang teduh, sejuk, indah, luas, dan tidak berisik. Kriteria lokasi beristirahat di luar ruangan yang paling sesuai menurut karyawan yaitu $26 \%$ teduh, $4 \%$ sejuk, $40 \%$ indah, $10 \%$ tidak berisik, $6 \%$ luas, serta $14 \%$ memilih kriteria yang lebih dari satu juga terdapat responden yang memberikan alternatif jawaban lain seperti tidak berdebu, dan nyaman (Gambar 56).

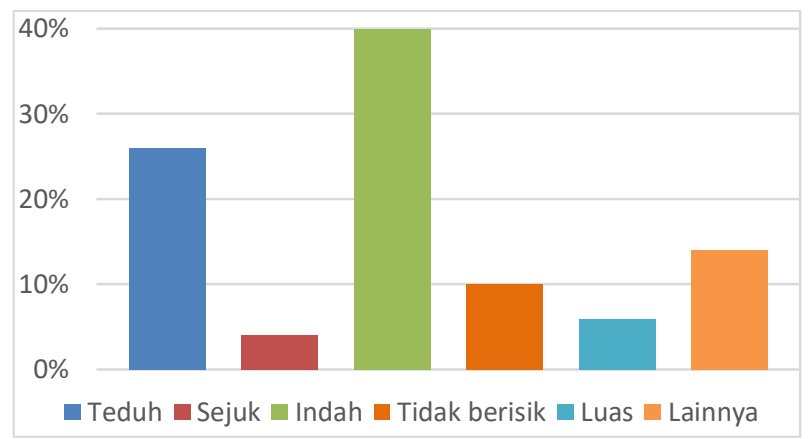

Gambar 56 Persepsi Karyawan terhadap Kriteria Lokasi Beristirahat

\section{Analisis Persepsi dan Preferensi Masyarakat}

Persepsi dan preferensi masyarakat didapatkan dari hasil kuesioner dan wawancara. Responden yang dipilih adalah masyarakat dekat lokasi kawasan industri. Masyarakat yang dipilih adalah masyarakat yang berada di Kelurahan Kebonsari Kecamatan Citangkil Kota Cilegon. Responden dipilih yaitu masyarakat umum berjumlah 30 orang. Analisis ini mencakup analisis persepsi masyarakat terhadap kondisi lokasi industri dan RTH di dalamnya.

Dari hasil sebaran kuesioner, responden yang terpilih adalah masyarakat yang sudah tinggal di dekat lokasi kawasan industri lebih dari 10 tahun sebanyak $70 \%$ dan 30\% lainnya tinggal di dekat lokasi kawasan industri kurang dari 10 tahun (Gambar 57). Masyarakat tersebut memiliki kriteria usia dan pekerjaan yang bermacam-macam. Sebagian masyarakat bekerja di dalam kawasan industri sebagai buruh pabrik, karyawan, atau berdagang.

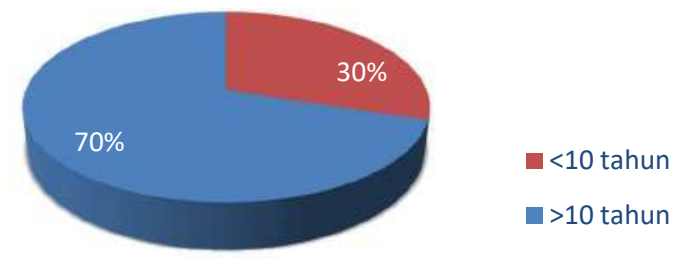

Gambar 57 Karakteristik Masyarakat Berdasarkan Lamanya Tinggal

Berdasarkan persepsi masyarakat, sebanyak $60 \%$ masyarakat menilai bahwa kawasan industri PT KS dapat menjaga kondisi lingkungan di sekitarnya. 40\% masyarakat lainnya berpendapat belum menjaga kondisi lingkungan di sekitarnya 
(Gambar 58). Masyarakat merasakan dampak negatif yang diberikan yaitu kualitas udara yang kurang baik di permukiman dalam jangka waktu yang cukup lama. Menurut masyarakat, PT KS mulai memperhatikan lingkungan beberapa tahun belakangan ini, dan masyarakat mengapresiasi kinerja PT KS tersebut.

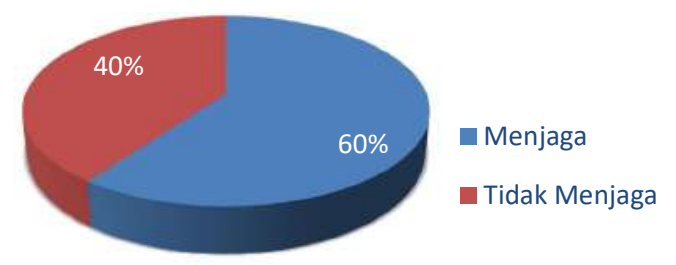

Gambar 58 Persepsi masyarakat terhadap Peran Industri pada Lingkungan

Jika dilihat dari banyaknya aktivitas masyarakat di dalam kawasan industri, sebagian masyarakat sering berada di kawasan industri terutama masyarakat yang memiliki mata pencaharian di dalam kawasan industri ataupun beraktivitas di sekitar kawasan industri. Aktivitas masyarakat yang dilakukan di dalam kawasan industri yaitu sebanyak $40 \%$ bekerja di kawasan industri dan 50\% hanya lewat di sekitar kawasan industri, serta 10\% memilih lainnya yaitu berdagang di kantin pabrik (Gambar 59).

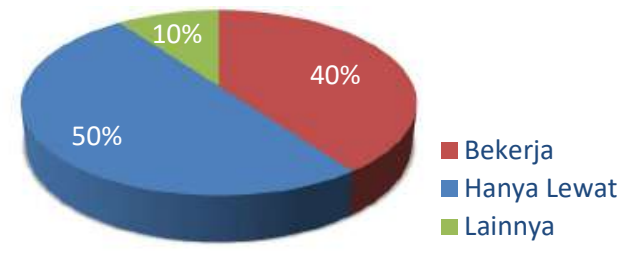

Gambar 59 Karakteristik Masyarakat berdasarkan Aktivitas

Secara umum, keberadaan kawasan industri memberikan keuntungan bagi masyarakat di sekitarnya. Keuntungan merupakan faktor penting yang harus diberikan oleh suatu industri terutama untuk mempertahankan keberadaannya. Menurut masyarakat, industri ini memberikan keuntungan terutama dalam bidang perekonomian. Hal ini sesuai dengan sebaran kuesioner dimana semua responden menilai industri memberikan keuntungan yaitu dalam memberikan lapangan pekerjaan dan meningkatkan perekonomian masyarakat.

Keuntungan tersebut juga diimbangi beberapa dampak yang diberikan terhadap lingkungan. Sebanyak 30\% responden menilai kerugian yang diberikan oleh PT KS yaitu kualitas udara yang menurun akibat tercemarnya udara oleh debu dan polusi dalam jangka waktu yang cukup lama, meskipun sekarang polusi sudah sangat berkurang (Gambar 60). Sisanya 70\% menganggap kawasan industri tidak memberikan kerugian (Gambar 60). Masyarakat yang tidak merasa dirugikan ini merupakan masyarakat yang tidak mendapatkan dampak langsung dari industri ataupun masyarakat yang jarang masuk ke kawasan industri. 


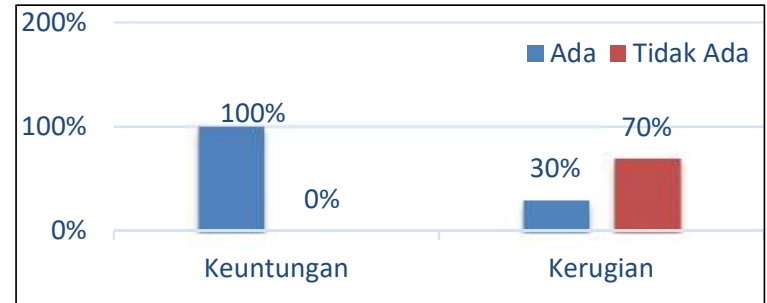

Gambar 60 Keuntungan dan Kerugian menurut Masyarakat

Penilaian masyarakat terhadap kawasan industri yaitu cendurung terdiri dari lebih banyak bangunan dengan kondisi yang panas dan sedikit kotor. Sebanyak $60 \%$ responden menilai industri cenderung didominasi bangunan dan $40 \%$ responden menilai terdapat bangunan dan beberapa tanaman (Gambar 61).

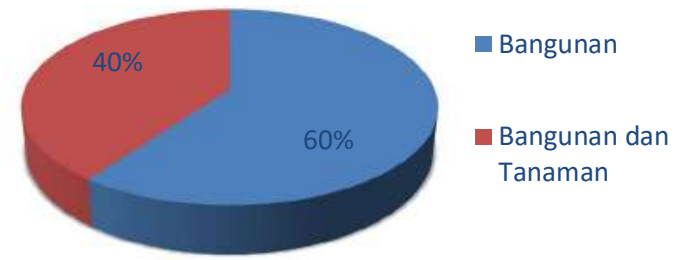

Gambar 61 Persepsi Masyarakat terhadap Kawasan Industri

Masyarakat yang merasa nyaman di beberapa tempat pada kedua lokasi industri, dipengaruhi oleh adanya bangunan dan beberapa tanaman. Bangunan dan tanaman ini dianggap memberi kenyamanan, terutama tanaman dapat mengurangi kondisi yang panas dan silau, serta mampu memberi kesejukan dan mengurangi udara kotor. Masyarakat yang merasa nyaman adalah sebesar $40 \%$ dan yang tidak merasa nyaman sebesar 60\% (Gambar 62). Responden merasa tidak nyaman karena suhu lingkungan di sekitar pabrik yang cukup tinggi, terutama di siang hari, tetapi cukup banyak responden yang merasa nyaman. Terdapat banyak faktor yang memberikan kenyamanan di kawasan industri yaitu suhu udara yang tidak panas, tidak adanya debu, tidak bising, banyaknya tanaman dan sebagainya. Menurut 63\% responden suhu udara yang tidak panas dapat memberikan kenyamanan di kawasan industri, sedangkan 20\% tidak banyak debu dapat memberikan kenyamanan. Sisanya sebanyak $17 \%$ responden memilih lainnya, yaitu banyaknya pepohonan dan tidak bising dapat memberikan kenyamanan di kawasan industri (Gambar 63).

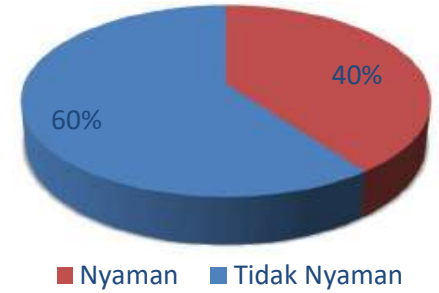

Gambar 62 Persepsi Masyarakat terhadap Kenyamanan 


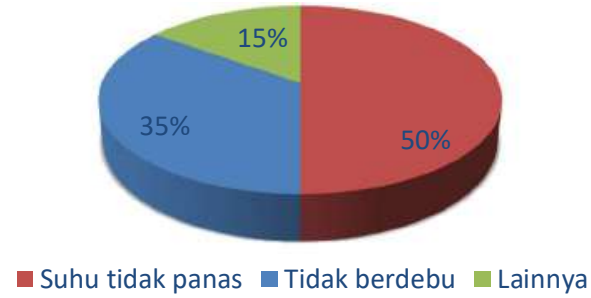

Gambar 63 Persepsi Masyarakat terhadap Faktor Pendorong Kenyamanan

Selanjutnya mengenai persepsi masyarakat terhadap istilah serta makna dari ruang terbuka hijau (RTH). Sebagian besar masyarakat di Kelurahan Kebonsari umumnya tidak mengetahui tentang RTH tetapi masyarakat pada umumnya memahami pentingnya fungsi tanaman yang dapat mempercantik ruang atau lahan, selain itu juga mampu memberikan rasa teduh dan sejuk. Sebanyak 100\% responden tidak mengetahui istilah RTH. Namun semua responden setuju jika lingkungan yang banyak tanamannya mampu memberikan rasa sejuk, bersih, dan sehat.

Suasana yang dirasakan manusia saat berada di tempat yang banyak terdapat pohon maupun tanaman lainnya berbeda dengan di lingkungan yang tidak terdapat tanaman. Responden 100\% merasa lebih nyaman dan teduh saat berada di lingkungan yang banyak terdapat pohon maupun tanaman lainnya. Responden menilai bahwa RTH sangat penting karena dapat memberikan udara bersih, suasana menjadi sejuk, dan menyaring polusi udara.

RTH di kawasan industri memiliki berbagai fungsi penting. Berdasarkan hasil wawancara, responden menilai RTH dibutuhkan agar polusi tidak keluar dari kawasan industri, agar dapat menurunkan suhu kawasan industri, dan menjadi tempat yang nyaman bagi karyawan di kawasan industri. Mengenai persepsi masyarakat terhadap RTH di kawasan industri PT KS, sebanyak 8\% responden menilai PT KS sudah memiliki ruang terbuka hijau yang baik sedangkan 92\% responden menjawab belum baik (Gambar 64). Hal ini dikarenakan masyarakat tidak mengetahui standar ruang terbuka hijau yang baik bagi kawasan industri.

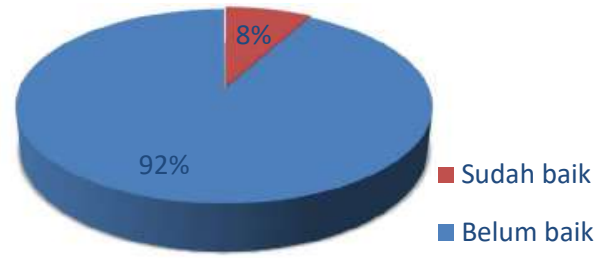

Gambar 64 Persepsi terhadap RTH Kawasan Industri PT KS

Jika suatu area hanya diisi bangunan dan perkerasan saja tanpa tanaman akan sangat gersang, panas, dan tidak nyaman. Terutama di kawasan industri tersebut pastinya semakin panas tanpa tanaman serta tidak ada yang mampu menyerap polusi. Seluruh responden menilai jika kawasan industri hanya diisi bangunan dan perkerasan saja tanpa tanaman akan sangat gersang, panas, dan tidak nyaman. Lain halnya jika suatu area industri tidak hanya berisi bangunan saja tetapi juga didominasi tanaman pasti akan terasa lebih sejuk dan nyaman. Adanya tanaman 
pada RTH yang membatasi kawasan pabrik menurut masyarakat setempat dapat mengurangi panas (Gambar 65).

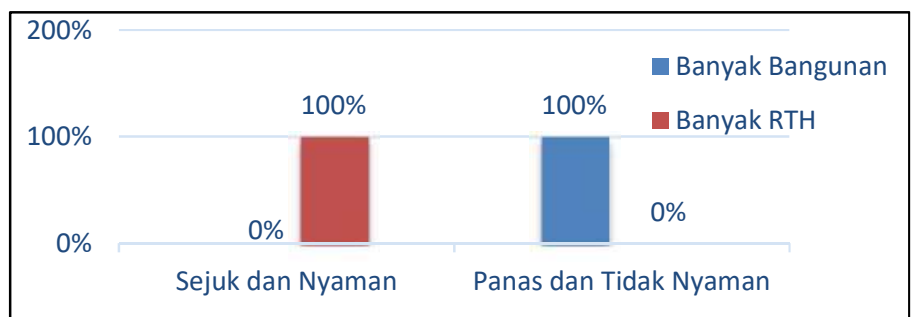

Gambar 65 Persepsi Masyarakat terhadap Kondisi Lingkungan yang didominasi Bangunan dan Tanaman

Menurut masyarakat RTH dapat memperbaiki kondisi kawasan industri. RTH yang ada saat ini sudah cukup banyak hanya saja masyarakat masih merasa kurang nyaman karena masyarakat masih merasa RTH yang ada belum berfungsi dengan baik sebagai penyaring debu. RTH yang diharapkan masyarakat adalah RTH yang dapat dimanfaatkan dengan baik khususnya RTH dengan dominasi penutupan pohon di dalamnya. Selain itu masyarakat juga menginginkan RTH yang tertata dengan baik sehingga kawasan industri terlihat lebih indah dan udara lebih sejuk, penambahan tanaman pohon diperbanyak lagi agar dapat menyaring polusi sehingga tidak mencapai jalan raya dan permukiman.

\section{Analisis SWOT}

Penentuan strategi perbaikan kondisi ruang terbuka hijau di kawasan Industri PT Krakatau Steel baik kualitas maupun kuantitasnya adalah dengan menggunakan analisis SWOT. Caranya adalah dengan menganalisis faktor-faktor internal dan eksternal yang dimiliki oleh ruang terbuka hijau di lokasi tersebut, hasil diskusi dengan pengelola, karyawan, warga setempat, serta hasil pengamatan. Faktor internal terdiri atas kekuatan (strength) dan kelemahan (weakness), sedangkan faktor eksternal terdiri atas peluang (opportunities) dan ancaman (threats). Kemudian nilai-nilai faktor ini diketahui dengan cara mengajukan kuesioner kepada responden (Lampiran 3). Responden yang diwawancarai oleh penulis berjumlah 4 orang, yaitu Kepala Divisi General Affair, Kepala Bagian Pembibitan, Kepala bagian Pemeliharaan, dan Karyawan.

\section{Identifikasi kekuatan, kelemahan, peluang, dan ancaman Kekuatan (Strength)}

a. Terdapat pembagian tugas dalam pengelolaan RTH

Perusahaan PT Krakatau Steel memiliki divisi yang bertanggung jawab dalam pengelolaan RTH, yaitu Divisi General Affair yang memiliki sub-divisi pembibitan serta sub-divisi pemeliharaan RTH.

b. Terdapat upaya penghijauan lingkungan secara berkelanjutan

Keenam pabrik di PT Krakatau Steel yaitu Cold Rolling Mill, Hot Strip Mill, Direct Reduction Plant, Wire Rod Plant, Slab Steel Plant, dan Billet Steel Plant 
melakukan upaya gerakan penghijauan lingkungan masing-masing pabrik. Biasanya acara tersebut dilakukan pada hari perayaan atau acara kerja bakti pada akhir pekan.

c. Upaya perusahaan terhadap penambahan tanaman baru pada RTH

PT Krakatau Steel (PT KS) memiliki program untuk mempertahankan serta menambah penghijauan di kawasan industrinya melalui antisipasi pohon yang mati dan mengganti dengan yang baru. Cukup banyak tanaman yang tumbang karena usianya yang sudah tua, lalu ditanam kembali dengan bibit tanaman yang baru.

d. Pihak perusahaan memiliki pembibitan untuk menyuplai kebutuhan tanaman.

Kebutuhan pohon di kawasan industri PT KS cukup banyak dan beragam, maka dari itu PT KS memiliki area pembibitan yang berada di luar kawasan industri. Tanaman di area pembibitan sebagian besar tanaman pohon, dan sebagian kecil lainnya tanaman hias. Tanaman di area pembibitan ini juga dapat diminta oleh masyarakat untuk kegiatan-kegiatan penghijauan di lingkungan masyarakat.

e. Terdapat area taman di lingkungan kawasan industri

Terdapat dua taman yang berlokasi di CRM dan Masjid HSM yang menjadi pelembut bagi suasana lingkungan yang sebagian besar bangunan pabrik. Taman tersebut menjadi daya tarik tersendiri bagi karyawan untuk dapat beristirahat disana.

f. Kesadaran karyawan tentang pentingnya RTH

Sebagian besar karyawan mengetahui apa itu RTH dan menyadari bahwa RTH penting karena menghasilkan suasana sejuk, menyaring polusi di kawasan, menambah kenyamanan, menurunkan suhu udara, menyegarkan pikiran, dan memberi keteduhan. Karyawan juga sangat menginginkan RTH yang ada dikembangkan dengan lebih baik, sehingga dapat menjadi tempat beristirahat dan menghilangkan kejenuhan mereka.

\section{Kelemahan (Weakness)}

a. Dominasi oleh bengunan pabrik yang cukup padat

Kawasan Industri PT KS didominasi oleh bangunan pabrik. Ruang terbuka yang tersisa merupakan ruang-ruang yang siap dijadikan ruang terbangun, contohnya pada project blast furnace merupakan proyek pembangunan pabrik baru di kawasan industri. Sebagian besar ruang yang telah ada merupakan ruang terbangun sehingga menyisakan sedikit ruang terbuka terutama ruang terbuka hijau yang dapat menjaga kualitas lingkungan kawasan industri.

b. Kurangnya sarana dan prasarana untuk pemeliharaan RTH

Tanaman yang baru ditanam di kawasan industri PT KS umumnya cepat mati karena sering terjadi kemarau panjang. Tenaga kerja untuk pemeliharaan RTH juga masih sangat terbatas. Karena itu sangat dibutuhkan sarana dan prasarana yang memadai untuk pemeliharaan RTH agar tanaman dapat terpelihara dengan baik, akan tetapi saat ini sarana dan prasarana yang ada belum memadai.

c. Belum ada tenaga ahli yang mengerti tentang RTH

Menurut Laporan Penghijauan PT KS 2015-2016, belum adanya tenaga ahli yang mengerti tentang RTH menyebabkan RTH dikelola oleh tenaga kerja seadanya. Menurut ketua sub-divisi pembibitan, mereka cukup mengerti tentang penanaman, pemangkasan, dan pemeliharaan, tetapi mereka kurang memahami mengenai penataan RTH agar berfungsi secara maksimal dan berkelanjutan.

d. Perusahaan belum memiliki standar operasional procedure dalam pemeliharaan RTH 
Berdasarkan Laporan Penghijauan PT KS 2015-2016, perusahaan belum memiliki standar pemeliharaan untuk dijadikan acuan dalam melaksanakan kegiatan pemeliharaan. Belum adanya pelaporan yang baik dan terintegrasi menyebabkan kondisi RTH kurang terpantau dengan baik.

e. Pihak pengelola RTH masih sulit mengajukan permohonan dana untuk pengembangan RTH.

Keterbatasan dana menjadi faktor pembatas yang cukup berpengaruh dalam pengembangan RTH. Banyak rencana pengembangan RTH baru yang belum terealisasikan karena kurangnya dana, kemudian pemeliharaan RTH untuk pembelian pupuk, kebutuhan air, serta tenaga kerja masih kurang.

f. RTH belum megakomodasi fasilitas beristirahat bagi karyawan

Berdasarkan hasil kuesioner, sebagian besar RTH belum bisa digunakan menurut karyawan. Hal tersebut didasari oleh beberapa faktor, seperti pohon peneduh yang belum cukup. Pohon peneduh tentu saja mempengaruhi kenyamanan di RTH, karena dapat menurunkan suhu di kawasan industri yang sangat panas.

\section{Peluang (Opportunities)}

a. Keberadaan kawasan industri sebagai penyedia lapangan pekerjaan

Kawasan industri merupakan penyedia lapangan pekerjaan bagi masyarakat sekitar. Masyarakat membutuhkan keberadaan kawasan industri tersebut. Banyak sekali masyarakat yang bekerja sebagai karyawan, buruh pabrik, berdagang, atau penjaga keamanan kawasan industri.

b. Perhatian pemerintah kota terhadap RTH

Pemerintah Kota Cilegon mengeluarkan RTRW 2010-2030 mengenai ketentuan umum zonasi kawasan perindustrian yang menyatakan bahwa pengembangan kawasan perindustrian harus dilengkapi taman-taman lingkungan dan jalur hijau (green belt) sebagai penyangga atau buffer antar fungsi kawasan, serta sarana pengelolaan limbah.

c. Pembatasan perluasan lahan industri

Berdasarkan RTRW 2010-2030 para pelaku industri tidak boleh memperluas lahan industrinya karena pemerintah Kota Cilegon telah menetapkan lahan seluas \pm 2.615 Ha sebagai lahan untuk para pelaku industri di Kota Cilegon yang terintegrasi dalam Kawasan Industri Krakatau.

d. Terdapat kelompok masyarakat yang peduli lingkungan

Terdapat kelompok masyarakat menaruh perhatian besar terhadap keadaan lingkungan, karena kawasan industri berlokasi dekat dengan permukiman. Masyarakat yang tergabung dengan organisasi peduli lingkungan Cilegon telah melakukan penghijauan pada area di luar kawasan tetapi berdekatan dengan kawasan industri. Selain itu, terdapat kelompok petani yang menjaga kawasan hutan alami yang di tengahnya terdapat sumber mata air Rawa Dano yang airnya digunakan sebagai air baku untuk kawasan industri.

\section{Ancaman (Threats)}

a. Bencana alam

Lokasi Kawasan Industri yg dekat dengan pantai membuat kawasan rentan terkena bencana alam. Di sebelah selatan kawasan industri merupakan jalan raya dan permukiman yang drainasenya kurang baik, saat terjadi hujan sering menjadi banjir dan berdampak pada bagian selatan kawasan industri. 
b. Hama penyakit yang menyerang tanaman

Tanaman di kawasan industri banyak terkena hama penyakit yang menyerang bagian daun. Kurangnya pengetahuan pihak pengelola RTH tentang pengendalian hama penyakit membuat hama penyakit tersebut dibiarkan begitu saja.

c. Iklim yang kurang mendukung pertumbuhan tanaman

Suhu udara di Kawasan Industri yang cukup panas menyebabkan sebagian tanaman tidak dapat tumbuh dan mati. Suhu panas dari pabrik dan debu juga merusak sebagian besar tanaman.

d. Kurangnya pengetahuan masyarakat terhadap RTH

Berdasarkan hasil wawancara, sebagian besar masyarakat Kota Cilegon tidak mengetahui istilah RTH. Masyarakat hanya mengetahui lahan yang ditanami tanaman, atau istilah taman. Masyarakat juga kurang memahami pentingnya RTH di lingkungannya.

\section{Penilaian Faktor Internal dan Eksternal}

Tabel 22 Penilaian Tingkat Kepentingan Faktor Internal

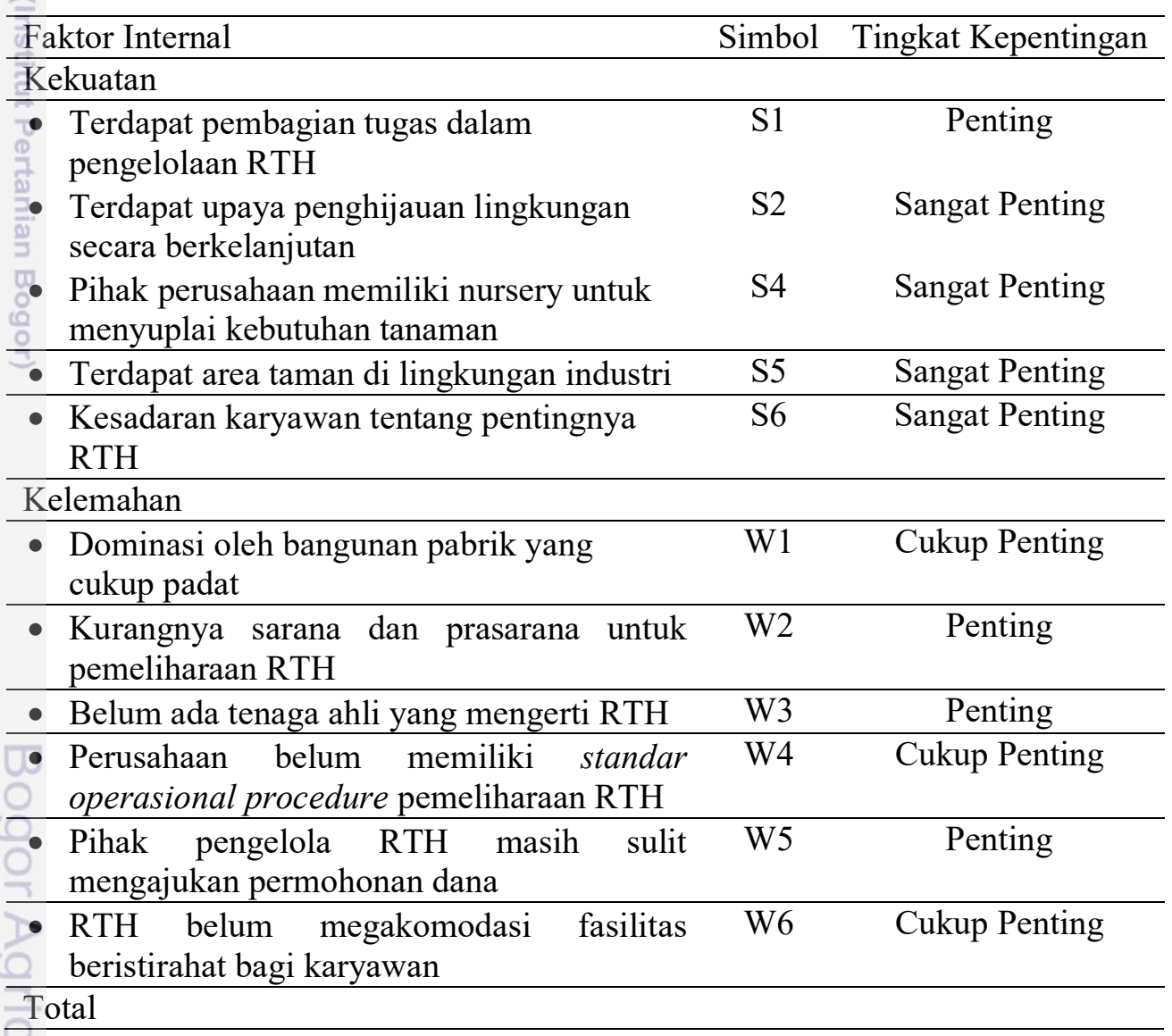


Tabel 23 Penilaian Tingkat Kepentingan Faktor Eksternal

\begin{tabular}{lcc}
\hline Faktor Eksternal & Simbol & $\begin{array}{c}\text { Tingkat } \\
\text { Kepentingan }\end{array}$ \\
\hline Peluang & & \\
\hline $\begin{array}{l}\text { Keberadaan kawasan industri sebagai } \\
\text { penyedia lapangan pekerjaan }\end{array}$ & $\mathrm{O} 1$ & Penting \\
- Perhatian pemerintah kota terhadap RTH & $\mathrm{O} 2$ & Penting \\
- Pembatasan perluasan lahan industri & $\mathrm{O} 3$ & Penting \\
- Terdapat kelompok masyarakat yang peduli & $\mathrm{O} 4$ & Penting \\
$\quad \begin{array}{l}\text { lingkungan } \\
\text { Ancaman }\end{array}$ & & \\
\hline - Bencana alam & $\mathrm{T} 1$ & Cukup Penting \\
- Hama penyakit yang menyerang tanaman & $\mathrm{T} 2$ & Penting \\
- Iklim yang kurang mendukung pertumbuhan & $\mathrm{T} 3$ & Penting \\
$\quad \begin{array}{l}\text { tanaman } \\
\text { - Kurangnya pengetahuan masyarakat } \\
\text { terhadap RTH }\end{array}$ & $\mathrm{T} 4$ & Cukup Penting \\
\hline Total & & \\
\hline
\end{tabular}

Selanjutnya masing-masing faktor diberikan penilaian yang menunjukkan besarnya keterkaiatan atau pengaruhnya. Penilainnya dilakukan dengan memberikan nilai 4 untuk pengaruh sangat penting, 3 untuk pengaruh penting, 2 untuk pengaruh cukup penting, dan 1 untuk pengaruh kurang penting. Penilaian ini disajikan dalam bentuk tabel yang mencakup penilaian yang hasil akhirnya adalah bobot keseluruhan tiap faktor. Total dari keseluruhan bobot pada masing-masing faktor harus bernilai 1,0 untuk mengetahui faktor mana yang paling dominan (Tabel 24 dan 25).

Tabel 24 Penentuan Nilai Bobot Faktor Internal

\begin{tabular}{|c|c|c|c|c|c|c|c|c|c|c|c|c|c|c|}
\hline & S1 & S2 & S3 & S4 & S5 & S6 & W1 & $\mathrm{W} 2$ & W3 & W4 & W5 & W6 & Total & Bobot \\
\hline S1 & & 3 & 2 & 3 & 3 & 3 & 2 & 1 & 1 & 2 & 1 & 2 & 23 & 0,08 \\
\hline S2 & 1 & & 1 & 2 & 2 & 2 & 1 & 1 & 1 & 1 & 1 & 1 & 14 & 0,05 \\
\hline S3 & 2 & 3 & & 3 & 3 & 3 & 2 & 1 & 1 & 2 & 1 & 2 & 23 & 0,08 \\
\hline S4 & 1 & 2 & 1 & 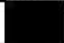 & 2 & 2 & 1 & 1 & 1 & 1 & 1 & 1 & 14 & 0,05 \\
\hline S5 & 1 & 2 & 1 & 2 & . & 2 & 1 & 1 & 1 & 1 & 1 & 1 & 14 & 0,05 \\
\hline S6 & 1 & 2 & 1 & 2 & 2 & . & 1 & 1 & 1 & 1 & 1 & 1 & 14 & 0,05 \\
\hline W1 & 2 & 3 & 2 & 3 & 3 & 3 & . & 1 & 1 & 2 & 1 & 2 & 23 & 0,08 \\
\hline W2 & 3 & 4 & 3 & 4 & 4 & 4 & 3 & 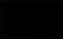 & 2 & 3 & 2 & 3 & 35 & 0,12 \\
\hline W3 & 2 & 3 & 2 & 3 & 3 & 3 & 2 & 1 & . & 2 & 1 & 2 & 24 & 0,08 \\
\hline W4 & 3 & 4 & 3 & 4 & 4 & 4 & 3 & 2 & 2 & 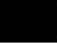 & 2 & 3 & 34 & 0,12 \\
\hline W5 & 3 & 4 & 3 & 4 & 4 & 4 & 3 & 2 & 2 & 3 & . & 3 & 35 & 0,12 \\
\hline \multirow[t]{2}{*}{ W6 } & 2 & 3 & 2 & 3 & 3 & 3 & 2 & 1 & 1 & 2 & 1 & & 23 & 0,08 \\
\hline & & & & Tota & & & & & & & & & 276 & 1 \\
\hline
\end{tabular}


Tabel 25 Penentuan Nilai Bobot Faktor Eksternal

\begin{tabular}{ccccccccccc}
\hline & $\mathrm{O} 1$ & $\mathrm{O} 2$ & $\mathrm{O} 3$ & $\mathrm{O} 4$ & $\mathrm{~T} 1$ & $\mathrm{~T} 2$ & $\mathrm{~T} 3$ & $\mathrm{~T} 4$ & Total & Bobot \\
\hline $\mathrm{O} 1$ & & 2 & 2 & 2 & 2 & 1 & 1 & 2 & 12 & 0,11 \\
$\mathrm{O} 2$ & 2 & & 2 & 2 & 2 & 1 & 1 & 2 & 12 & 0,11 \\
$\mathrm{nyyyyyyyyynn} \mathrm{O} 3$ & 2 & 2 & & 2 & 2 & 1 & 1 & 2 & 12 & 0,11 \\
$\mathrm{O} 4$ & 2 & 2 & 2 & & 2 & 1 & 1 & 2 & 12 & 0,11 \\
$\mathrm{n} 1$ & 2 & 2 & 2 & 2 & & 1 & 1 & 2 & 12 & 0,11 \\
$\mathrm{n} 2$ & 3 & 3 & 3 & 3 & 3 & & 2 & 3 & 20 & 0,18 \\
\cline { 2 - 8 } $\mathrm{T} 3$ & 3 & 3 & 3 & 3 & 3 & 2 & & 3 & 20 & 0,18 \\
\cline { 2 - 7 } $\mathrm{T} 4$ & 2 & 2 & 2 & 2 & 2 & 1 & 1 & & 12 & 0,11 \\
\hline 0
\end{tabular}

Setelah didapatkan bobot masing-masing faktor selanjutnya diberikan rating pada masing-masing faktor yaitu 4 (sangat penting), 3 (penting), 2 (sedang), dan 1 (kurang). Berdasarkan bobot dan rating yang sudah didapatkan selanjutnya dilakukan perhitungan skor masing-masing faktor dengan mengalikan bobot dan rating (Tabel 26 dan 27) Menurut David (2008), jika nilai total skor IFE dan EFE lebih dari 2,5 makan nilai tersebut menunjukkan kondisi yang kuat.

Tabel 26 Penilaian Faktor Internal di Kawasan Industri PT. KS

\begin{tabular}{|c|c|c|c|}
\hline Faktor Internal & Bobot & Rating & Skor \\
\hline \multicolumn{4}{|l|}{ Kekuatan } \\
\hline $\begin{array}{l}\text { - Terdapat pembagian tugas dalam pengelolaan } \\
\text { RTH }\end{array}$ & 0,08 & 3 & 0,24 \\
\hline $\begin{array}{l}\text { Terdapat upaya penghijauan lingkungan secara } \\
\text { berkelanjutan }\end{array}$ & 0,05 & 4 & 0,20 \\
\hline $\begin{array}{l}\text { - Upaya perusahaan terhadap penambahan tanaman } \\
\text { baru pada RTH }\end{array}$ & 0,08 & 3 & 0,24 \\
\hline $\begin{array}{l}\text { Pihak perusahaan memiliki nursery untuk } \\
\text { menyuplai kebutuhan tanaman }\end{array}$ & 0,05 & 4 & 0,20 \\
\hline - Terdapat area taman di lingkungan industri & 0,05 & 4 & 0,20 \\
\hline - Kesadaran karyawan tentang pentingnya RTH & 0,05 & 4 & 0,20 \\
\hline \multicolumn{4}{|l|}{ Kelemahan } \\
\hline - Dominasi oleh bangunan pabrik yang cukup padat & 0,08 & 3 & 0,24 \\
\hline $\begin{array}{l}\text { - Kurangnya sarana dan prasarana untuk } \\
\text { pemeliharaan RTH }\end{array}$ & 0,12 & 2 & 0,24 \\
\hline Belum ada tenaga ahli yang mengerti RTH & 0,08 & 2 & 0,16 \\
\hline $\begin{array}{l}\text { - Perusahaan belum memiliki standar operasional } \\
\text { procedure pemeliharaan RTH }\end{array}$ & 0,12 & 3 & 0,36 \\
\hline $\begin{array}{l}\text { - Pihak pengelola RTH masih sulit mengajukan } \\
\text { permohonan dana }\end{array}$ & 0,12 & 2 & 0,24 \\
\hline $\begin{array}{l}\text { - RTH belum megakomodasi fasilitas beristirahat } \\
\text { bagi karyawan }\end{array}$ & 0,08 & 3 & 0,24 \\
\hline Total & 1,00 & 37 & 2,76 \\
\hline
\end{tabular}


Tabel 27 Penilaian Faktor Eksternal di Kawasan Industri PT. KS

\begin{tabular}{llcc}
\hline Faktor Eksternal & Bobot & Rating & Skor \\
\hline Peluang & & & \\
\hline - Keberadaan kawasan industri sebagai & 0,11 & 3 & 0,32 \\
$\quad$ penyedia lapangan pekerjaan & & & \\
- Perhatian pemerintah kota terhadap RTH & 0,11 & 3 & 0,32 \\
- Pembatasan perluasan lahan industri & 0,11 & 3 & 0,32 \\
- Terdapat kelompok masyarakat yang peduli & 0,11 & 3 & 0,32 \\
$\quad$ lingkungan & & & \\
\hline $\begin{array}{l}\text { Ancaman } \\
\text { - Bencana alam }\end{array}$ & 0,11 & 3 & 0,32 \\
- Hama penyakit yang menyerang tanaman & 0,18 & 2 & 0,35 \\
- Iklim yang kurang mendukung pertumbuhan & 0,18 & 2 & 0,35 \\
$\quad$ tanaman & 0,11 & 3 & 0,32 \\
- Kurangnya pengetahuan masyarakat & & & \\
$\quad$ terhadap RTH & 1,00 & 22 & 2,64 \\
\hline Total & & & \\
\hline
\end{tabular}

Berdasarkan perhitungan pada tabel, kondisi internal RTH pada kawasan industri PT KS kuat karena memiliki nilai di atas 2,5. Dari skor yang didapat dari pembobotan rangking di atas, akan diketahui posisi RTH kawasan pada kuadran tertentu yang dapat menyatakan kekuatan dan kelemahannya melalui matriks internal-eksternal (IE). Matriks IE didasarkan pada dua dimensi kunci yaitu skor total matriks IFE pada sumbu x dan skor total matriks EFE pada sumbu y. Total skor metriks IFE adalah 2,76 dan total skor matriks EFE adalah 2,64. Hasil pemetaan matriks IFE dan EFE untuk RTH kawasan industri PT KS dapat dilihat pada Gambar 66.

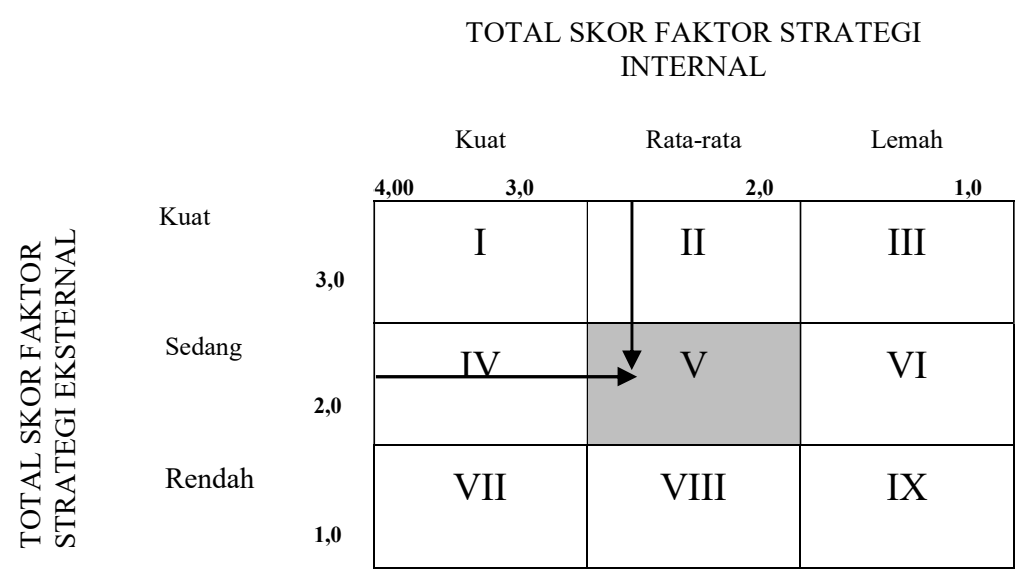

Gambar 66 Matriks Internal Eksternal

Berdasarkan nilai total skor IFE dan EFE, kondisi ruang terbuka hijau pada kawasan industri PT KS berada di skala V. Skala V menunjukkan bahwa ruang terbuka hijau ini berada pada posisi hold and maintain. Strategi yang sesuai adalah 
strategi seperti pengembangan, dalam hal ini program optimalisasi pengelolaan dan pemanfaatan ruang terbuka hijau yang telah ada.

\section{Matriks SWOT}

Setelah melakukan identifikasi faktor internal dan eksternal, kemudian akan dianalisis ke dalam matriks SWOT untuk mendapatkan langkah-langkah perbaikan ruang terbuka hijau yang sesuai. Pada tahap ini dilakukan pencocokan faktor-faktor internal dan eksternal yang dimiliki RTH Kawasan Industri PT KS, yaitu dengan menyesuaikan kekuatan dan kelemahan yang dimiliki dengan peluang dan ancaman yang diprediksi akan terjadi. Pada matriks ini ditunjukkan beberapa alternatif strategi perbaikan yang dapat dilakukan oleh pihak pengelola RTH Kawasan Industri PT KS. Terdapat 9 strategi pengelolaan, yaitu 3 strategi SO (strengthopportunity), 3 strategi ST (strength-threat), 2 strategi WO (weakness-opportunity), dan 1 strategi WT (weakness-threat). Keseluruhan strategi ini disusun dengan mempertimbangkan faktor-faktor kekuatan internal dan eksternal yang terkait. Pencocokan tersebut akan dijabarkan pada Tabel 28. 
Tabel 28 Matriks SWOT RTH Kawasan Industri PT KS

\begin{tabular}{|c|c|c|}
\hline Internal & $\begin{array}{l}\text { Opportunities / Peluang } \\
\text { 1. Keberadaan kawasan } \\
\text { industri sebagai } \\
\text { penyedia lapangan } \\
\text { pekerjaan } \\
\text { 2. Perhatian pemerintah } \\
\text { kota terhadap RTH } \\
\text { 3. Pembatasan perluasan } \\
\text { lahan industri } \\
\text { 4. Terdapat kelompok } \\
\text { masyarakat yang peduli } \\
\text { lingkungan }\end{array}$ & $\begin{array}{l}\text { Threats (Ancaman) } \\
\text { 1. Bencana Alam } \\
\text { 2. Hama penyakit yang } \\
\text { menyerang tanaman } \\
\text { 3. Iklim yang kurang } \\
\text { mendukung } \\
\text { pertumbuhan tanaman } \\
\text { 4. Kurangnya pengetahuan } \\
\text { masyarakat terhadap } \\
\text { RTH }\end{array}$ \\
\hline $\begin{array}{l}\text { Strength / Kekuatan } \\
\text { 1. Terdapat pembagian tugas } \\
\text { dalam pengelolaan RTH } \\
\text { 2. Terdapat upaya } \\
\text { penghijauan lingkungan } \\
\text { secara berkelanjutan } \\
\text { 3. Upaya perusahaan terhadap } \\
\text { penambahan tanaman baru } \\
\text { pada RTH } \\
\text { 4. Pihak perusahaan memiliki } \\
\text { nursery } \\
\text { 5. Terdapat area taman di } \\
\text { lingkungan industri } \\
\text { 6. Kesadaran karyawan } \\
\text { tentang pentingnya RTH }\end{array}$ & $\begin{array}{l}\text { Strategi SO } \\
\text { 1. } \\
\text { Bekerja sama dengan } \\
\text { pemerintah kota } \\
\text { dalam } \\
\text { mengembangkan RTH } \\
\text { penyangga di luar } \\
\text { kawasan industri } \\
\text { 2. } \\
\text { Mengadakan upaya } \\
\text { penghijauan bersama } \\
\text { kelompok masyarakat } \\
\text { 3. Pembuatan taman } \\
\text { baru serta } \\
\text { mengembangkan } \\
\text { taman lama melalui } \\
\text { peningkatan fasilitas }\end{array}$ & \begin{tabular}{l}
\multicolumn{1}{c}{ Strategi ST } \\
1. Pelatihan pemeliharaan \\
tanaman bagi karyawan \\
pemelihara RTH \\
2. Perusahaan \\
mengadakan CSR \\
kepada masyarakat \\
dalam rangka \\
pentingnya RTH dan \\
lingkungan \\
3. Peningkatan variasi \\
tanaman yang tahan \\
terhadap iklim
\end{tabular} \\
\hline $\begin{array}{l}\text { Weakness (Kelemahan) } \\
\text { 1. Dominasi oleh bangunan } \\
\text { pabrik yang cukup padat } \\
\text { 2. Kurangnya sarana dan } \\
\text { prasarana untuk } \\
\text { pemeliharaan RTH } \\
\text { 3. Belum ada tenaga ahli } \\
\text { yang mengerti RTH } \\
\text { 4. Perusahaan belum } \\
\text { memiliki standar } \\
\text { operasional procedure } \\
\text { pemeliharaan RTH } \\
\text { 5. Pihak pengelola RTH } \\
\text { masih sulit mengajukan } \\
\text { permohonan dana } \\
\text { 6. RTH belum dapat } \\
\text { mengakomodasi fasilitas } \\
\text { beristirahat bagi karyawan }\end{array}$ & \begin{tabular}{ll}
\multicolumn{1}{c}{ Strategi WO } \\
1. & $\begin{array}{l}\text { Mempertahankan dan } \\
\text { mengoptimalkan }\end{array}$ \\
luasan RTH yang ada \\
2. & Perusahaan bekerja \\
sama dengan \\
pemerintah untuk \\
mempekerjakan \\
tenaga ahli yang \\
mengerti RTH
\end{tabular} & $\begin{array}{l}\quad \text { Strategi WT } \\
\text { 4. Perbaikan sistem } \\
\text { pengelolaan RTH } \\
\text { melalui penetapan } \\
\text { standar operasional } \\
\text { procedure yang jelas } \\
\text { dan terintegrasi serta } \\
\text { peningkatan sarana dan } \\
\text { prasarana. }\end{array}$ \\
\hline
\end{tabular}

\section{Pembuatan Tabel Rangking Alternatif Strategi}

Setelah didapatkan beberapa alternatif strategi, selanjutnya dilakukan penentuan peringkat dari setiap alternatif strategi tersebut dengan cara menjumlahkan semua skor dari setiap faktor strategis terkait. Skor yang lebih tinggi 
mengindikasikan strategi yang lebih menjadi prioritas (Jannah 2013). Adapun penjabaran penentuan peringkat strategi dijelaskan pada Tabel 29.

Tabel 29 Perangkingan Alternatif Strategi Perbaikan RTH

\begin{tabular}{|c|c|c|c|c|}
\hline No & Alternatif Strategi & $\begin{array}{l}\text { Keterkaitan dengan } \\
\text { Unsur SWOT }\end{array}$ & Skor & Rangking \\
\hline $\begin{array}{l}\text { (C) } \\
\frac{1}{2} \\
\frac{0}{\hat{2}} \\
\frac{0}{0}\end{array}$ & $\begin{array}{l}\text { Perbaikan sistem pengelolaan } \\
\text { RTH melalui penetapan } \\
\text { standar operasional procedure } \\
\text { yang jelas dan terintergrasi } \\
\text { serta peningkatan sarana dan } \\
\text { prasarana. }\end{array}$ & $\begin{array}{c}\mathrm{W} 1, \mathrm{~W} 4, \mathrm{~W} 5, \mathrm{~T} 1 \\
\mathrm{~T} 2, \mathrm{~T} 3\end{array}$ & 1,55 & 1 \\
\hline 2 & $\begin{array}{l}\text { Perusahaan mengadakan CSR } \\
\text { kepada masyarakat dalam } \\
\text { rangka pentingnya RTH dan } \\
\text { lingkungan }\end{array}$ & $\begin{array}{c}\mathrm{S} 2, \mathrm{~S} 3, \mathrm{~S} 4, \mathrm{~S} 5, \mathrm{~S} 6 \\
\mathrm{~T} 4\end{array}$ & 1,36 & 2 \\
\hline 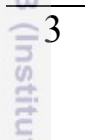 & $\begin{array}{l}\text { Pelatihan pemeliharaan } \\
\text { tanaman bagi karyawan } \\
\text { pemelihara RTH }\end{array}$ & S3, S5, S6, T2, T3 & 1,35 & 3 \\
\hline 4 & $\begin{array}{l}\text { Pembuatan taman baru dan } \\
\text { mengembangkan taman lama } \\
\text { melalui peningkatan tanaman } \\
\text { dan fasilitas untuk dipakai } \\
\text { karyawan beristirahat }\end{array}$ & $\begin{array}{c}\mathrm{S} 2, \mathrm{~S} 3, \mathrm{~S} 4, \mathrm{~S} 5, \mathrm{~S} 6 \\
\mathrm{O} 1\end{array}$ & 1,28 & 4 \\
\hline 5 & $\begin{array}{l}\text { Mempertahankan dan } \\
\text { mengembangkan industri tanpa } \\
\text { perluasan lahan }\end{array}$ & $\mathrm{W} 1, \mathrm{O} 1, \mathrm{O} 2, \mathrm{O} 3$ & 1,20 & 5 \\
\hline 6 & $\begin{array}{l}\text { Peningkatan variasi tanaman } \\
\text { yang tahan terhadap iklim }\end{array}$ & $\mathrm{S} 2, \mathrm{~S} 3, \mathrm{~S} 4, \mathrm{~S} 5, \mathrm{~T} 3$ & 1,19 & 6 \\
\hline 7 & $\begin{array}{l}\text { Mengadakan upaya } \\
\text { penghijauan lingkungan } \\
\text { bersama kelompok masyarakat }\end{array}$ & S2, S3, S4, S6, O4 & 1,16 & 7 \\
\hline 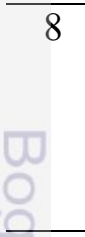 & $\begin{array}{l}\text { Bekerja sama dengan } \\
\text { pemerintah kota dalam } \\
\text { mengembangkan RTH } \\
\text { penyangga di luar kawasan } \\
\text { industri }\end{array}$ & $\mathrm{S} 2, \mathrm{~S} 4, \mathrm{O} 2, \mathrm{O} 3$ & 1,04 & 8 \\
\hline 9 & $\begin{array}{l}\text { Perusahaan bekerja sama } \\
\text { dengan pemerintah untuk } \\
\text { mempekerjakan tenaga ahli } \\
\text { yang mengerti RTH }\end{array}$ & $\mathrm{W} 3, \mathrm{O} 1, \mathrm{O} 2$ & 0,80 & 9 \\
\hline
\end{tabular}

Tabel di atas adalah hasil rekomendasi dari rumusan permasalahan yang ada untuk mempertahankan dan mengoptimalkan fungsi dan pengelolaan RTH di kawasan industri PT KS. Masing-masing strategi memiliki peringkat kepentingan yang telah diurutkan, di mana peringkat 1 adalah strategi yang paling diunggulkan, sedangkan peringkat 2 hingga 7 adalah strategi yang dapat dilaksanakan setelahnya. 


\section{Evaluasi}

\section{Aspek Kecukupan RTH}

Secara persen luasan, kawasan industri sudah cukup baik karena walaupun dengan kepadatan bangunan dan area terbangunnya saat ini, kawasan tersebut sudah memiliki RTH seluas $12 \%$ dari total lahan dan sudah memenuhi kewajiban RTH minimum 10\% dari total lahan. Hal ini sesuai dengan UU No. 26 Tahun 2007 dan Peraturan Menteri Perindustrian No.40 tahun 2016 yang mengharuskan bsahwa RTH minimal kawasan industri yaitu $10 \%$ dari luas area.

Jika dibandingkan dengan Peraturan Menteri Perindustrian No.40 tahun 2016 yang mengharuskan bahwa standar RTH di kawasan industri minimal memiliki taman dan sabuk hijau (green belt), maka kawasan industri belum memenuhi standar tersebut karena belum memiliki sabuk hijau (green belt). Menurut Peraturan Kementrian Pekerjaan Umum No.5 Tahun 2008, Sabuk hijau merupakan RTH yang berfungsi sebagai daerah penyangga dan untuk membatasi perkembangan suatu penggunaan lahan (batas kota, pemisah kawasan, dan lain lain) atau membatasi aktivitas satu dengan aktivitas lainnya agar tidak saling mengganggu, serta pengamanan dari faktor lingkungan sekitarnya. RTH yang menjadi penyangga di kawasan industri hanya berupa RTH penyangga antar pabrik, tetapi belum ada Sabuk Hijau (green belt) yang menjadi pembatas antara kawasan industri dengan permukiman yang berlokasi di sebelah selatan kawasan industri. Pemukiman menjadi rentan terkena dampak dari keberadaan kawasan industri tersebut terutama emisi udara karena arah angin terbesar yaitu dari utara ke selatan. Menurut Grey dan Deneke (1978) pola penanaman yang tegak lurus terhadap arah angin, konsentris mengelilingi sumber polusi dan menggunakan pembatas (tanaman) yang rapat mampu mengurangi polusi udara.

RTH pada tapak didominasi oleh lahan kelas 3 yaitu RTH yang ditanami penutup tanah dan pohon. Klasifikasi RTH pada tapak terdiri dari empat jenis yaitu taman, lapangan, jalur hijau jalan, dan daerah penyangga (buffer zone). Penutupan lahan RTH masih dapat dimaksimalkan lagi. Lahan kelas 1 yang berupa lapangan dapat diperbaiki agar kualitasnya meningkat menjadi lahan kelas 3 yaitu lapangan ditanam vegetasi peneduh seperti beringin (Ficus benjamina) di area di sekeliling lapangan. Selain itu diperlukan juga penempatan bangku taman untuk mengakomodasi kenyamanan karyawan yang beristirahat. Lahan kelas 3 yang mendominasi tapak terdiri dari buffer zone yang luasnya $30 \mathrm{Ha}$. Lahan tersebut dapat ditingkatkan kualitasnya dengan menambahkan semak. Penempatan semak menambah kerapatan vegetasi dan memodfikasi iklim mikro. Pada lahan kelas 5 yang terdiri dari Taman CRM, Taman Masjid HSM, dan RTH Kantor HSE sudah memiliki nilai ekologis tinggi, terutama pemanfaatan energi matahari oleh tanaman yang semakin efisien. Lahan kelas 5 harus tetap dipertahankan karena kualitas lahan tersebut sudah sangat baik.

Menurut persepsi karyawan, RTH belum cukup dalam mengakomodasi aktivitas karyawan beristirahat. Di dalam kawasan industri hanya ada dua taman yakni taman CRM dan taman masjid HSM yang tidak dapat dikunjungi karyawan yang bekerja pada pabrik yang lokasinya jauh dari taman tersebut. Karyawan mengharapkan dibuatnya taman-taman baru pada pabrik yang belum memiliki taman, agar dapat dipakai karyawan beristirahat serta dapat mengurangi kejenuhan kerja. 
Selain di dalam kawasan industri, perlu juga penambahan RTH di luar kawasan industri yang yang dapat mencegah polusi udara dari kawasan industri mencapai jalan raya dan permukiman. Lahan terbuka di bagian selatan kawasan industri dapat dimanfaatkan dengan bekerja sama dengan pemerintah dan warga yang memakai lahan tersebut secara ilegal untuk membuat perkebunan pisang. Perkebunan pisang tersebut dapat dipertahankan dan dapat ditambahkan tanamantanaman lain pada sisi lahan yang sebagian besar masih kosong.

\section{Aspek Kenyamanan Termal}

Berdasarkan hasil analisis kenyamanan termal didapatkan nilai THI (Temperature Humadity Index) rata-rata yang bervariasi pada keenam lokasi pengukuran di kawasan industri (Tabel 30). Menurut Nieuwolt, kategori Nyaman yaitu $21 \leq \mathrm{THI} \leq 24$, Cukup nyaman yaitu $24<\mathrm{THI} \leq 26$, dan Tidak nyaman yaitu THI $>26$. Dari hasil pengukuran, seluruh lokasi pengukuran baik di perkerasan maupun di bawah naungan, dengan waktu pengukuran pagi, siang, dan sore hari, menunjukkan bahwa RTH kurang memberi kenyamanan bagi manusia.

Tabel 30 Hasil Perhitungan Nilai THI

\begin{tabular}{llcc}
\hline \multirow{2}{*}{ No. } & \multirow{2}{*}{ Lokasi Pengukuran } & \multicolumn{2}{c}{ Nilai THI di Kawasan Industri } \\
\cline { 3 - 4 } & & Di bawah naungan & Perkerasan \\
\hline 1. & Taman CRM & 27,7 & 31,3 \\
\hline 2. & Taman Masjid HSM & 28,8 & 28,6 \\
\hline 3. & Jalur Hijau Jalan & 27,6 & 28,5 \\
\hline 4. & RTH Pabrik DRP & 27,3 & 28,6 \\
\hline 5. & RTH Kantor HSE & 27 & 27,1 \\
\hline 6. & Lapangan & 27 & 28,6 \\
\hline & Rata-rata & 27,5 & 28,8 \\
\hline
\end{tabular}

Nilai THI rata-rata berdasarkan hasil pengukuran adalah diatas 26 yang menunjukkan kondisi keenam lokasi pada kawasan industri tersebut tidak nyaman. Akan tetapi jika dibandingkan antara nilai THI pada kondisi dengan naungan dan tanpa naungan, hasilnya berbeda. Hasil pengukuran dengan kondisi di bawah naungan pohon memiliki nilai THI rata-rata sebesar 27,5 sedangkan kondisi tanpa naungan pohon nilai THI rata-rata sebesar 28,8 . Hal ini menunjukkan bahwa dengan adanya pohon maka pada area tersebut kondisi kenyamanannya meningkat.

Nilai THI cenderung rendah pada lokasi RTH Kantor HSE dan lapangan. Kedua lokasi tersebut memiliki nilai berbeda dengan THI lainnya, dimana THI lainnya nilainya lebih dari 27. Pada lapangan terdapat tanaman penaung yang tajuknya cukup lebar, sedangkan RTH HSE didominasi oleh tanaman penaung yang jarak tanamnya cukup rapat, dan lokasinya tidak berdekatan dengan pabrik. Oleh karena itu pada RTH tersebut nilai THI menjadi lebih rendah dibandingkan lokasi pengukuran yang lainnya.

Nilai THI cenderung tinggi pada RTH yang berdekatan dengan pabrik, seperti pada Taman CRM, Taman Masjid HSM, dan RTH Pabrik DRP. Hal tersebut karena pabrik mengeluarkan panas sekitar $600-1600^{\circ} \mathrm{C}$ dalam pengolahan produknya, sehingga dapat mempengaruhi suhu di luar pabrik atau suhu pada RTH. Nilai THI tertinggi di lokasi di bawah naungan pohon yaitu pada Taman Masjid HSM. Taman 
tersebut hanya berjarak beberapa meter dari pabrik, dengan kondisi vegetasi yang mendominasi yaitu jenis tanaman hias. Keberadaan pohon peneduh pada taman tersebut hanya pada satu sisi taman saja, sehingga kurang mempengaruhi kenyamanan pada taman tersebut. Oleh karena itu pada RTH yang dekat dengan bangunan pabrik juga perlu ditingkatkan fungsi tanamannya terutama tanaman yang tahan dan mampu menyerap bahan pencemar. Selain itu juga dibutuhkan tanaman yang mampu menurunkan suhu untuk mengurangi kondisi kawasan yang cenderung padat dan panas akibat dominasi bangunan maupun kegiatan industri di dalam pabrik.

Dari hasil pengukuran kenyamanan termal, dapat disimpulkan bahwa RTH masih belum memberikan kenyamanan bagi manusia. Namun hal tersebut berbanding terbalik dengan persepsi karyawan. Karyawan berpendapat bahwa kawasan industri sudah nyaman, karena karyawan sudah beradaptasi dengan kondisi kawasan industri. Kenyamanan tersebut dipengaruhi keberadaan tanaman, yaitu pohon, semak, dan rumput, terutama tanaman jenis pohon dianggap memberi kenyamanan karena berfungsi sebagai peneduh dan penjerap debu dari pabrik. Namun diketahui bahwa karyawan menganggap tanaman peneduh belum cukup sehingga perlunya penambahahan peneduh pada setiap RTH. Perlu juga penambahan tanaman di dekat bangunan pabrik agar pabrik tidak hanya didominasi perkerasan yang membuat lingkungan menjadi panas, namun dengan keberadaan tanaman dapat meningkatkan kenyamanan di sekitar bangunan pabrik. Karyawan juga merasakan ketidaknyamanan saat mengunjungi RTH. Faktor yang paling berpengaruh pada ketidaknyamanan tersebut adalah keterbatasan fasilitas pada RTH.

\section{Rekomendasi}

\section{Aspek Kecukupan RTH}

RTH di kawasan industri PT Krakatau Steel sudah memenuhi UU No. 26 Tahun 2007 dan Peraturan Menteri Perindustrian No.40 tahun 2016 yaitu luas RTH minimal $10 \%$ dari luas kawasan. RTH tersebut terdiri dari taman, jalur hijau, lapangan, dan daerah penyangga. Menurut karyawan dengan adanya RTH yang ada sekarang masih belum dapat mengakomodasi aktivitas mereka. RTH yang ada sekarang masih perlu dikembangkan. Berikut rekomendasi yang dapat meningkatkan kecukupan RTH di kawasan industri PT KS.

1. Pembuatan taman baru pada kawasan pabrik yang belum memiliki taman

Keberadaan taman merupakan RTH yang penting bagi karyawan sebagai tempat beristirahat dan menghilangkan kejenuhan kerja. Taman yang sudah ada yaitu Taman CRM yang berlokasi di Pabrik CRM, dan Taman Masjid HSM yang berlokasi di Pabrik HSM. Dengan adanya kedua taman tersebut faktanya belum mencukupi kebutuhan karyawan karena lokasi taman tersebut jauh dari pabrik lainnya. Wilayah pabrik lain seperti WRM, DRP, BSP, SSP, dan HSE belum terdapat keberadaan taman dan karyawan mengaku membutuhkan tambahantambahan taman.

Taman-taman dapat dibuat di dekat gedung perkantoran dan tidak di dekat pabrik yang berbahaya. Taman tersebut dapat ditambahkan vegetasi estetik dan 
pohon peneduh serta fasilitas taman seperti gazebo, kolam kecil, serta bangku taman. Gazebo pada taman terbuat dari kayu agar dapat memberikan kesan natural. Semua elemen taman dibuat secara permanen dan diletakkan di bawah naungan pohon untuk mencegah pemindahan fasilitas oleh pengguna. Berikut adalah ilustrasi taman pada kawasan pabrik (Gambar 67).

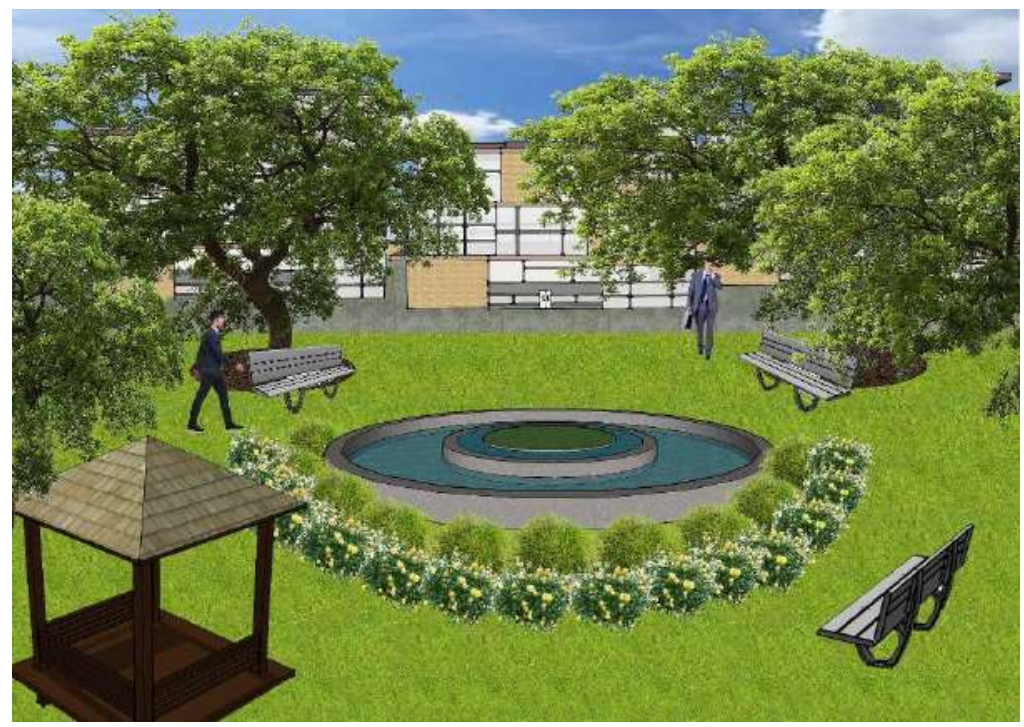

Gambar 67 Ilustrasi Taman pada Kawasan Pabrik

2. Mengembangkan RTH penyangga di luar kawasan industri PT KS

Kawasan industri PT KS telah memiliki daerah penyangga antar pabrik tetapi belum memiliki sabuk hijau (green belt) yang membatasi kawasan industri dan permukiman. Keberadaan ruang terbuka di sebelah selatan yang dimiliki pemerintah dapat dimanfaatkan oleh perusahaan menjadi sabuk hijau (green belt). Ruang terbuka tersebut sampai saat ini masih sebagian besar kosong ditumbuhi rumput sehingga dipakai peternak untuk memberi makan ternak, atau sebagian kecilnya ditanami liar oleh warga seperti tanaman pisang.

Tanaman untuk sabuk hijau (green belt) fungsinya terutama untuk pereduksi polutan. Pemilihan vegetasi untuk penjerap debu terutama yang memiliki daun yang rimbun, permukaan daun yang kasar atau berbulu, berdaun jarum, memiliki kerapatan trikoma tinggi, serta toleran terhadap polutan. Penanaman tegak lurus dengan arah angin, penanaman rapat/massif, penanaman semak dan pohon yang Tebat dan beraneka ragam serta massif, serta konfigurasi tanaman dapat berbentuk gerombol atau menumpuk.

Vegetasi pereduksi polutan yang dapat digunakan antara lain Teh-tehan pangkas (Acalypha sp.), Akasia daun besar (Accacia mangium), Bogenvil (Bougenvillea sp.), Mangga (Mangifera indica), Oleander (Nerium oleander) Angsana (Ptherocarphus indicus), Ketapang (Terminalia catappa). Vegetasi semak ditanam menutupi cabang pohon utama yang tidak sampai ke permukaan tanah untuk mencegah debu yang keluar dari kawasan.

Tanaman untuk sabuk hijau (green belt) fungsi lainnya sebagai pemecah angin agar debu dari kawasan industri tidak mencapai permukiman. Kriteria 
penanaman vegetasinya yaitu tanaman tinggi, perdu/semak, bermassa daun padat, ditanam berbaris atau membentuk massa; dan jarak tanam rapat $<3 \mathrm{~m}$. Vegetasi pemecah angin yang dapat digunakan antara lain Cemara angin (Casuarina equisetifolia), Kiara Payung (Felicium decipiens), Mahoni (Swietenia mahagoni), dan Tanjung (Mimusops elengi). Berikut adalah ilustrasi green belt (Gambar 68).

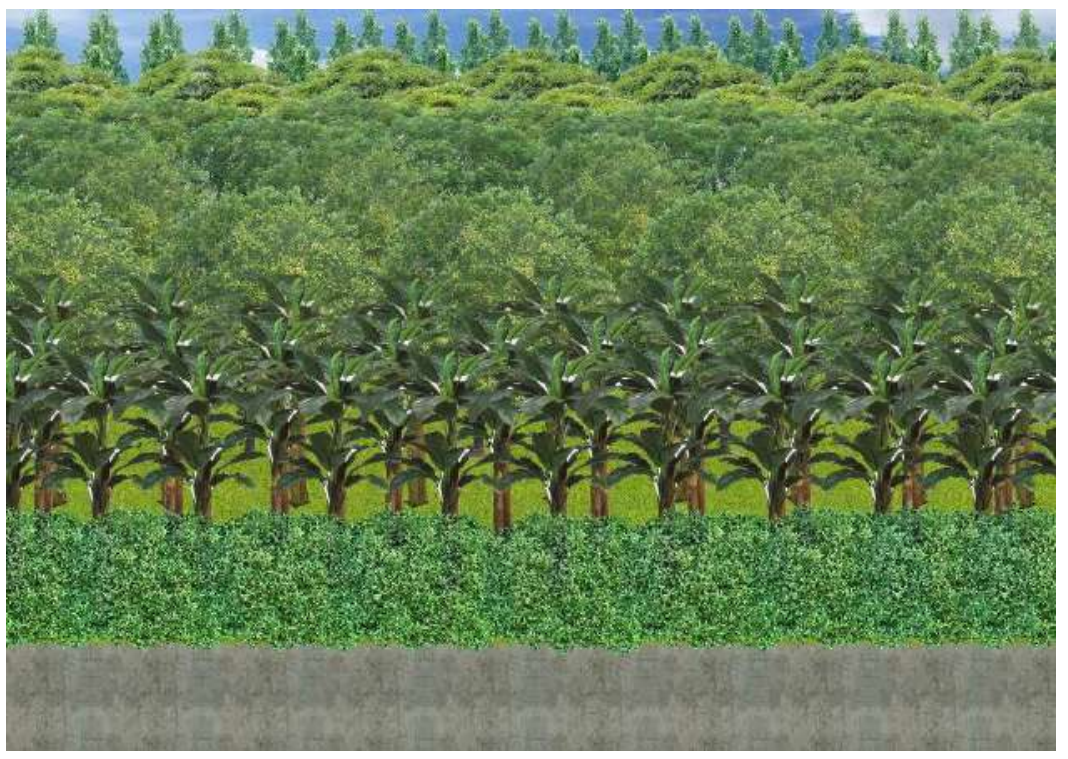

Gambar 68 Ilustrasi Green Belt

3. Meningkatkan penghijauan di dekat bangunan pabrik

Kawasan industri didominasi oleh bangunan pabrik dan perkerasan. Di dekat bangunan tidak terdapat adanya tanaman karena keberadaan RTH cukup terpisah dari bangunan pabrik sehingga membuat suasana menjadi sangat panas dan kering. Vegetasi sangat dibutuhkan untuk mengurangi kondisi tersebut. Penghijauan bisa diterapkan dengan memanfaatkan ruang-ruang baik berupa perkerasan maupun bukan perkerasan tetapi jarang terdapat aktivitas di dalamnya, dalam arti lain tidak dipakai berlalu lalang oleh kendaraan pengangkut produk. Namun jika sudah benarbenar tidak terdapat ruang kosong lagi penanaman bisa dilakukan pada bangunan dengan menerapkan tanaman dalam pot atau penanaman secara vertikal (vertical garden).

Kriteria pemilihan vegetasi untuk tanaman dalam pot atau vertical garden ini yaitu tanaman tidak berakar dalam sehingga mampu tumbuh baik dalam pot atau bak tanaman, relatif tahan terhadap kekurangan air, tahan dan tumbuh baik pada temperatur lingkungan yang tinggi, dan mudah dalam pemeliharaan. Vegetasi perdu atau semak yang dapat digunakan Akalipa merah (Acalypha wilkesiana), Bogenvil merah (Bougenvillea glabra), Palem Kuning (Chrysalidocaus lutescens), Puring (Codiaeum varigatum), Sikas (Cycas revolata), Soka daun besar (Ixora javonica), Azalea (Rhododendron indicum). Vegetasi ground cover yang dapat digunakan Rumput Gajah (Axonophus compressus), Rumput bermuda (Cynodon dactylon), Lantana ungu (Lantana camara). Berikut adalah ilustrasi penghijauan di dekat bangunan pabrik (Gambar 69). 


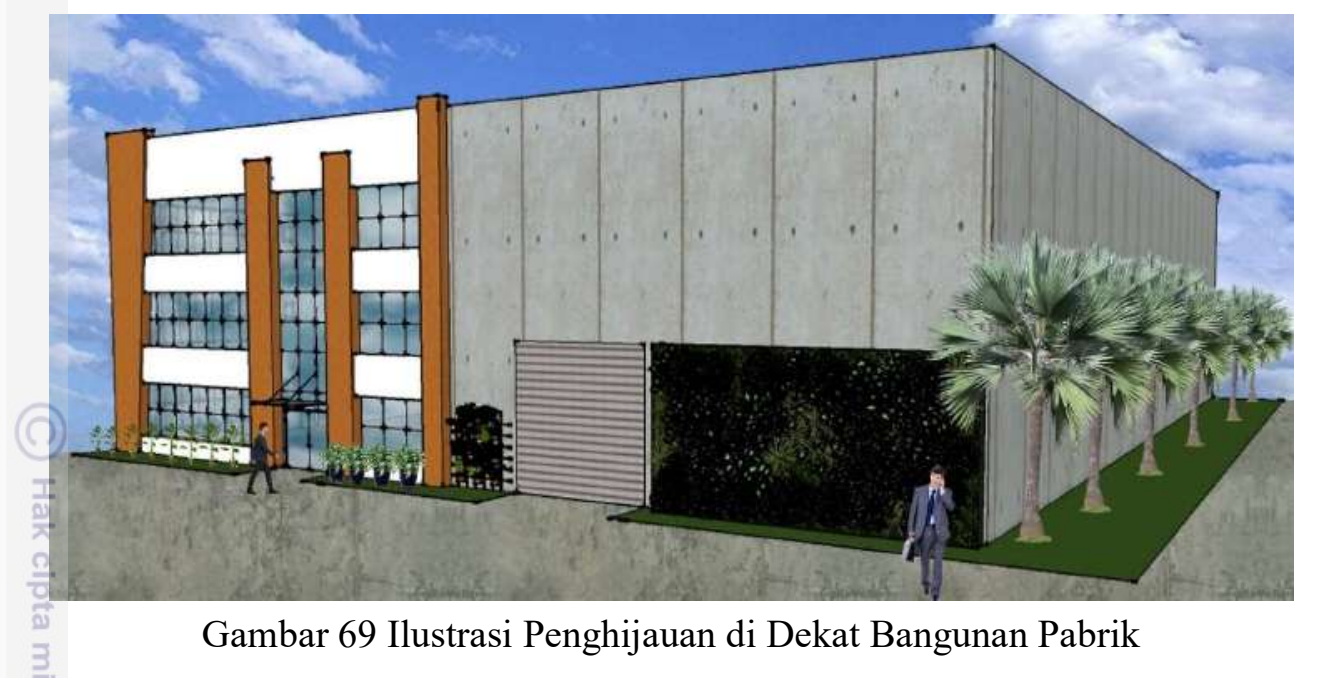

\section{Asspek Kenyamanan Termal}

Kenyamanan termal dapat diciptakan oleh beberapa faktor diantaranya suhu udara, kelembaban, intensitas penyinaran matahari, dan angin. Berdasarkan hasil penelitian dari pengukuran suhu dan kelembaban udara, area pengukuran yang berada di bawah naungan pohon mempunyai nilai kenyamanan yang lebih tinggi dibandingkan area pengukuran di atas perkerasan di dekat pabrik.

Vegetasi secara efektif dapat meningkatkan kenyamanan termal pada RTH. Namun, keefektifan vegetasi dalam meningkatkan kenyamanan termal dipengaruhi oleh faktor internal vegetasi tersebut. Secara umum yaitu bentuk tajuk dan kerapatan tajuk yang menjadi faktor paling berpengaruh dalam peningkatan kenyamanan termal. Bentuk tajuk cenderung bulat, spreading, dan kolumnar lebih efektif dalam ameliorasi iklim mikro, begitu pula tajuk yang rapat lebih efektif dibandingkan tajuk yang renggang. Berdasarkan hasil penelitian, taman CRM, taman Masjid HSM, lapangan, dan RTH DRP belum optimal fungsinya untuk meningkatkan kenyamanan termal karena penanaman vegetasi yang berjauhan membuat kenyamanan termal hanya dapat dirasakan saat berada di bawah naungan salah satu pohon.

Secara spesifik, rekomendasi vegetasi pada tapak penelitian yaitu perlu memerhatikan vegetasi eksisting di setiap tapak. Vegetasi eksisting di tapak sebaiknya dipertahankan, dan penambahan tanaman baru diperlukan untuk menambah kerapatan dan meningkatkan kenyamanan termal. Akan tetapi area yang memiliki vegetasi yang rapat menyebabkan kelembaban tinggi sehingga mengurangi kenyamanan tersebut. Oleh karena itu, pengaturan vegetasi perlu mempertimbangkan jarak tanam. Penanaman tanaman yang bertajuk lebar jarak tanam ideal adalah $5 \mathrm{~m} \times 5 \mathrm{~m}$, sedangkan penanaman pohon yang bertajuk kecil jarak tanam idealnya $3 \mathrm{~m} \times 3 \mathrm{~m}$. Karakter fisik tanaman yang dapat memodifikasi suhu (peneduh) berdasarkan ketetapan oleh Simonds (1983), Departemen Pekerjaan Umum Direktorat Jendral Bina Marga (1996), dan literatur lainnya seperti ketinggian kanopi lebih dari $2 \mathrm{~m}$, bentuk tauk spreading, bulat dome atau irreguler, massa daun padat dan daun tebal. Beberapa tanaman yang dapat memodifikasi suhu (peneduh) seperti Beringin (Ficus benjamina), Biola cantik (Ficus lyrata), Ketapang (Terminalia catappa) dan Trembesi (Samanea saman). 


\section{Strategi Pengembangan RTH}

Untuk mempertahankan dan mengembangkan RTH di kawasan industri PT Krakatau Steel dapat dilakukan sembilan strategi dari hasil analisis SWOT. Strategi ini diurutkan dari atas yaitu urutan terpenting untuk dilakukan dan strategi di bawahnya dapat dilakukan selanjutnya. Berikut adalah strategi yang dapat diterapkan oleh perusahan.

1. Perbaikan sistem pengelolaan RTH melalui penetapan standar operasional procedure yang jelas dan terintergrasi serta peningkatan sarana dan prasarana.

2. Perusahaan mengadakan CSR kepada masyarakat dalam rangka pentingnya RTH dan lingkungan

3. Pelatihan pemeliharaan tanaman bagi karyawan pemelihara RTH

4. Pembuatan taman baru dan mengembangkan taman lama melalui peningkatan tanaman dan fasilitas untuk dipakai karyawan beristirahat

5. Mempertahankan dan mengembangkan industri tanpa perluasan lahan

6. Peningkatan variasi tanaman yang tahan terhadap iklim

7. Mengadakan upaya penghijauan lingkungan bersama kelompok masyarakat

8. Bekerja sama dengan pemerintah kota dalam mengembangkan RTH penyangga di luar kawasan industri

9. Perusahaan bekerja sama dengan pemerintah untuk mempekerjakan tenaga ahli yang mengerti RTH

\section{SIMPULAN DAN SARAN}

\section{Simpulan}

Hasil penelitian menunjukkan bahwa RTH pada kawasan industri diklasifikasikan menjadi empat jenis, yaitu taman, jalur hijau jalan, buffer zone, dan lapangan. RTH di kawasan industri PT Krakatau Steel memiliki luas 34 ha yang merupakan $12 \%$ dari total 285 ha luas kawasan industri. Kecukupan luas RTH ini sudah sesuai dengan Undang-Undang Republik Indonesia No. 26 tahun 2007, dan Peraturan Menteri Perindustrian No.40 tahun 2016. Tetapi menurut persepsi sebagian besar karyawan yang berkerja lebih dari 20 tahun, kawasan industri belum memiliki fasilitas yang cukup pada RTH, kondisi peneduh pada RTH masih belum cukup, serta RTH kurang berfungsi dengan baik.

Kenyamanan termal RTH di kawasan industri tergolong belum sesuai karena berdasarkan perhitungan THI nilainya melebihi batas kenyamanan termal, tetapi peran vegetasi telah terbukti dapat memperbaiki nilai THI. Namun menurut persepsi karyawan kawasan industri sudah dalam kategori nyaman. Melalui penyebaran kuesioner diketahui bahwa karyawan menginginkan penambahan tanaman, vegetasi peneduh, taman kecil, dan fasilitas seperti gazebo dan tempat duduk. Sedangkan masyarakat menginginkan RTH berupa green belt yang menjadi penyangga antara kawasan industri dan permukiman. Hal tersebut juga sejalan dengan Peraturan Menteri Perindustrian No.40 tahun 2016 dan RTRW Kota Cilegon tahun 2010-2030 yang mengharuskan suatu kawasan industri memiliki green belt sebagai penyangga antar fungsi kawasan. 
RTH yang ada ini memerlukan pengembangan yang lebih lanjut untuk dapat meningkatkan kesesuaian RTH bagi karyawan dan masyarakat. Untuk meningkatkan kecukupan RTH yaitu pembuatan taman baru pada kawasan pabrik yang belum memiliki taman, mengembangkan RTH penyangga di luar kawasan industri PT KS, dan meningkatkan penghijauan di dekat bangunan pabrik. Untuk meningkatkan kenyamanan termal yaitu penambahan tanaman peneduh pada setiap RTH. Selain itu terdapat sembilan strategi pengembangan RTH yang dapat diterapkan oleh PT Krakatau Steel dengan berbagai pihak seperti karyawan, masyarakat, dan pemerintah.

\section{Saran}

Hasil dari penelitian ini diharapkan dapat menjadi masukan bagi pengelola RTH agar dapat menciptakan RTH yang lebih baik. Untuk kepentingan perkembangan ilmu pengetahuan, sebaiknya perlu dilakukan penelitian mengenai kemampuan setiap vegetasi dalam menjerap polusi di kawasan industri, sehingga vegetasi yang ditanam memiliki fungsi yang lebih efektif dan efisien.

\section{DAFTAR PUSTAKA}

Adhayani NL. 2005. Hubungan Penggunaan Lahan Terhadap Suhu Udara Sebagai Indikator Kenyamanan Kota Cibinong. [skripsi]. Bogor: Fakultas Matematika dan Ilmu Pengetahuan Alam, Institut Pertanian Bogor.

Aniqa ZH. 2011. Evaluasi Kesesuaian Fisik Ruang Terbuka Hijau di Kawasan Peruntukan Industri Bakalan Krapyak, Kecamatan Kaliwungu, Kabupaten Kudus [skripsi]. Bogor: Departemen Arsitektur Lanskap, Fakultas Pertanian, Institut Pertanian Bogor.

Asiani Y. 2007. Pengaruh kondisi Ruang Terbuka Hijau (RTH) pada Iklim Mikro di Kota Bogor [tesis]. Depok (ID): Universitas Indonesia.

[Bappeda] Badan Perencanaan dan Pembangunan Daerah Kota Cilegon. Profil Kota Cilegon. 2018. Cilegon (ID): Bappeda Kota Cilegon.

[BMKG] Badan Meteorologi Klimatologi dan Geofisika Klas II Serang. Kondisi Klimatologi Kecamatan Pulomerak. 2018. Serang (ID): BMKG Klas II Serang.

[BPS] Badan Pusat Statistik. Topografi Kota Cilegon. Cilegon (ID): Badan Pusat Statistik Kota Cilegon.

Booth NK. 1990. Basic Element of Landscape Architecture Design. Illnois (US): Waveland Press inc.

Budiyono A. 2001. Pencemaran udara : Dampak Pencemaran Udara pada Lingkungan [internet] [diunduh 17 Oktober 2018]. Tersedia pada: jurnal.lapan. go.id/index.php/berita_dirgantara/article/view/687

Carpenter PL, Walker TD, DeTurk PE. 1975. Plants in the Landscape. San Fransisco (US): W H. Freeman and Co.

David FR. 2008. Manajemen Strategi ke-10. Budi S, penerjemah; Jakarta: Salemba - Empat. Terjemahan dari: Strategic Management: Concepts and Cases, 10th ed. 
Dirdjojuwono RW. 2004. Kawasan industri di Indonesia: Sebuah Perencanaan dan Aplikasinya. Bogor: Pustaka Wirausaha Muda.

Dwiputri DA. 2012. Perencanaan Ruang Terbuka Hijau di Kawasan Pembangkit Listrik Tenaga Uap PT Krakatau Daya Listrik Cilegon Banten [skripsi]. Bogor: Departemen Arsitektur Lanskap, Fakultas Pertanian, Institut Pertanian Bogor.

Effendy S. 2014. Keterkaitan Ruang Terbuka Hijau Dengan Urban Heat Island Wilayah Jabotabek [disertasi]. Bogor: Program Pascasarjana, Institut Pertanian Bogor.

Ekawati D. 1998. Pengaruh Asap Kendaraan Bermotor Terhadap Struktur Anatomi Daun Beberapa Tanaman Hutan Kota [skripsi]. Bogor: Departemen Konservasi Sumberdaya Hutan dan Ekowisata, Fakultas Kehutanan, Institut Pertanian Bogor.

Farida. 2004. Dampak Pencemaran Terhadap Kesehatan [internet] [diunduh 17 Oktober 2018]. Tersedia pada: www.depkes.go.id.

Gomez F, Gil L, Jabaloyes J. 2004. Experimental Investigation on the Thermal Comfort in the City: Relationship with the Green Areas, Interaction with the Urban Microclimate. Building and Environment. 39: 1077-1086.

Grey GW, Deneke FJ. 1978. Urban Forestry. New York (US): John Willey and Sons, Inc.

Handoko. 1995. Klimatologi Dasar. Landasan Pemahaman Fisika Atmosfer dan Unsur-unsur Iklim. Jakarta (ID): PT Pustaka Jaya.

Handoko K, Tohir RK. 2015. Studi Iklim Mikro [internet] [diunduh 16 April 2018]. Tersedia pada: https:/media.neliti.com/1385665-ID-none

Hasni. 2009. Ruang Terbuka Hijau dalam Rangka Penataan Ruang [internet] [diunduh 22 November 2018]. Tersedia pada: portalgaruda.org/article.php\% Farticle

Hendrawan A. 2003. Optimalisasi Ruang Terbuka Hijau Untuk Remaja (Studi Kasus: Empat Ruang Terbuka Hijau di DKI Jakarta. Jakarta (ID): PSIL PPS UI.

Hidayat IW. 2010. The ecological role of trees and their interactions in forming the microclimate amenity of environment. Bumi Lestari. 10(2):182- 190.

Jahara LM. 2002. Perencanaan Hutan Kota Kawasan Industri Krakatau Kota Cilegon Banten [skripsi]. Bogor: Departemen Budidaya Pertanian, Fakultas Pertanian, Institut Pertanian Bogor.

Jannah M. 2013. Pengelolaan Lanskap Kompleks Masjid Al-Hurriyyah Sebagai Pusat Kegiatan Keislaman [skripsi]. Bogor (ID): Institut Pertanian Bogor.

[Kemenperin] Peraturan Menteri Perindustrian No.40 tahun 2016. 2016. Pedoman Teknis Kawasan Industri. Jakarta (ID): Menteri Perindustrian.

[KemenPU] Peraturan Menteri Pekerjaan Umum Nomor 5/PRT/M/2008. 2008. Pedoman Penyediaan dan Pemanfaatan Ruang Terbuka Hijau di Kawasan Perkotaan. Jakarta (ID): Menteri Pekerjaan Umum.

Kinnear TC, Taylor JR. 1991. Marketing Research : an applied approach. New York (US): McGraw-Hill

Kwanda T. 2000. Pengembangan kawasan industri di indonesia. Dimensi Teknik Arsitektur. 28(1):54.

Kristanto. 2004. Ekologi Industri. Yogyakarta (ID): Andi Offset.

Laurie M. 1985. Pengantar Kepada Arsitektur Pertamanan (terjemahan). Bandung (ID): Intermata 
Lestari G, Kencana IP. 2008. Galeri Tanaman Hias Lanskap. Bogor (ID): Penebar Swadaya.

Maimun. 2007. Hutan untuk Makhluk Hidup [internet]. [diunduh 14 April 2018]. Tersedia pada: acehrecoveryforum.org

Mc Gregor, Nieuwolt S. 1975. Tropical Climatology, an Introduction to The Climate Low Lattitude.

Nugroho DA. 2009. Perencanaan Ruang Terbuka Hijau Di Kawasan Industri Kota Bukit Indah Kabupaten Purwakarta [skripsi]. Bogor: Departemen Arsitektur Lanskap, Fakultas Pertanian, Institut Pertanian Bogor.

Paramitha C. 2013. Dampak Peleburan Industri Besi dan Baja Terhadap - Lingkungan dan Kesehatan Masyarakat [skripsi]. Bogor: Departemen Ekonomi Sumberdaya dan Lingkungan, Fakultas Ekonomi dan Manajemen, Institut Pertanian Bogor.

Porteus JL. 1983. Enviromental Aesthetich: Idea, Politics and Planning. New York (US): Cambridge University Press.

[PPRI] Peraturan Pemerintah Republik Indonesia No. 24 Tahun 2009. 2009. Kawasan Industri. Jakarta (ID): Presiden Republik Indonesia.

[PTKS] Penghijauan PT Krakatau Steel. 2018. Ruang Terbuka Hijau. Cilegon (ID): PT Krakatau Steel.

Purwanto E. 2007. Ruang Terbuka Hijau di Perumahan Graha Estetika Semarang [internet]. [diunduh 22 September 2017]. Tersedia pada: eprints.undip.ac.id/18510/

Rahmawati SN. 2014. Kemampuan Hutan Kota dalam Ameliorasi Iklim Mikro di Kampus IPB Dramaga (Studi Kasus Arboretum Arsitektur Lanskap [skripsi]. Bogor: Departemen Konservasi Sumberdaya Hutan dan Ekowisata, Institut Pertanian Bogor.

Rangkuti, F. 1997. Analisis SWOT Teknik Membedah Kasus Bisnis: Reorientasi Konsep Perencanaan Strategi untuk Menghadapi Abad 21. Jakarta: PT Gramedia Pustaka Utama.

Ramadani MN. 2013. Evaluasi Visual dan Fungsional Lapangan Golf Senayan National Golf Club [skripsi]. Bogor: Departemen Arsitektur Lanskap, Fakultas Pertanian, Institut Pertanian Bogor.

[RTRW] RTRW Kota Cilegon 2010-2030. 2010. Ketentuan Umum Zonasi Kawasan Perindustrian. Cilegon (ID): Badan Perencanaan dan Pembangunan Daerah.

Simonds JO. 1983. Landscape Architecture. New York (US): Mc Graw-Hill Book Co.

Setyawati DL. 2008. Iklim mikro dan kebutuhan ruang terbuka hijau di kota semarang. Manusia dan Lingkungan. 15(3): 125-140.

Suryowinoto MS. 1997. Flora Estetika: Tanaman Peneduh. Yogyakarta (ID): Penerbit Kanisius.

(Tinambunan RS. 2006. Analisis Kebutuhan Ruang Terbuka Hijau Di Kota Pekanbaru [tesis]. Bogor: Departemen Arsitektur Lanskap, Fakultas Pertanian, Institut Pertanian Bogor.

Turgeon AJ. 2002. Turfgrass Management. Sixth Edition. New. Jersey (US): Prentice Hall.

Tursilowati L. 2007. Use of remote sensing and GIS to compute THI as human comfort indicator related with land use-land cover change in surabaya (1994- 
2002). Di dalam: The $73^{\text {rd }}$ International Symposium on Sustainable Humanosphere 2007. Hlm 160-165.

[UURI] Undang-Undang Republik Indonesia No. 26 tahun 2007. 2007. Penataan Ruang. Jakarta (ID): Presiden Republik Indonesia.

Vitasari D. 2004. Evaluasi Tata Hijau Jalan pada Tiga Jalan Kawasan Pemukiman Besar di Kab. Bogor, Jawa Barat [skripsi]. Bogor: Departemen Arsitektur Lanskap, Fakultas Pertanian, Institut Pertanian Bogor.

Wardhana WA. 2004. Dampak Pencemaran Lingkungan. Yogyakarta: Andi Offset. Zahra AF, Sitawati, Suryanto A. 2014. Evaluasi Keindahan dan Kenyamanan Ruang Terbuka Hijau (RTH) Alun-alun Kota Batu. Jurnal Produksi Tanaman. 2(7): 524-532. 
Lampiran 1 Lembar Kuesioner Karyawan

KUESIONER PENELITIAN

EVALUASI KENYAMANAN TERMAL DAN KECUKUPAN RUANG TERBUKA HIJAU DI KAWASAN INDUSTRI PT KRAKATAU STEEL, KOTA CILEGON

Kepada Responden yang terhormat,

Dalam rangka menyelesaikan tugas akhir di Departemen Arsitektur Lanskap, Fakultas Pertanian, Institut Pertanian Bogor, diperlukan dukungan saudara untuk mengisi kuesioner ini.

Kuesioner ini diedarkan untuk mengetahui persepsi dan preferensi karyawan terhadap penggunaan ruang terbuka hijau $(\mathrm{RTH})$ di kawasan industri. Untuk itu, saya sangat mengharapkan kesediaan saudara meluangkan waktu untuk mengisi kuesioner ini. Masukan dan informasi yang jujur, benar dan akurat sangat diharapkan, agar informasi ilmiah yang akan disajikan benar-benar dapat dipertanggung jawabkan dihadapan semua pihak.

Terima kasih atas bantuan dan kesediaannya dalam mengisi kuesioner ini.

Lupita Rachma

\section{Identitas Responden}

Nama :

Usia :

Pendidikan Terakhir:

Pekerjaan/ Jabatan :

II. Pilihlah Salah Satu Jawaban Yang Paling Benar Menurut Pendapat Anda. Beri Tanda Silang (X) Pada Pilihan Anda dan Isilah Titik - Titik yang disediakan.

\section{A. Kawasan Industri}

1. Sudah berapa lama anda bekerja di PT Krakatau Steel?
a. $<5$ tahun
b. 5-10 tahun
c. $>5$ tahun
d. Lainnya, ....

2. Apakah menurut anda kegiatan industri di Krakatau Steel dapat menjaga kondisi lingkungan di sekitarnya?
a. Ya
b. Tidak

3. Apa pemikiran atau bayangan anda ketika berada di kawasan industri?

a. Banyak bangunan dan lingkungan cenderung panas, kotor, dan kering.

b.Banyak pepohonan dan tanaman lainnya sehingga terasa sejuk dan nyaman.

c. Banyak bangunan tetapi ada beberapa tanaman di sekitarnya. 


\section{B. Ruang Terbuka Hijau}

Ruang Terbuka Hijau (RTH) adalah bagian dari ruang-ruang terbuka (open spaces) suatu wilayah yang diisi oleh tumbuhan, tanaman, dan vegetasi (endemik, introduksi) guna mendukung manfaat langsung dan/atau tidak langsung yang dihasilkan oleh RTH dalam wilayah tersebut yaitu keamanan, kenyamanan, kesejahteraan, dan keindahan.

4. Apakah anda sudah mengetahui istilah ruang terbuka hijau (RTH) sebelumnya?
a. Ya
b. Tidak

5. Bagaimana menurut anda kondisi lingkungan yang banyak terdapat tanamannya?
a. Sejuk, bersih, dan sehat
b. Panas, kotor, dan lembab
c. Biasa saja

6. Apakah yang anda rasakan ketika berada di tempat yang banyak terdapat pohon maupun tanaman lainnya?

a. Merasa lebih nyaman dan teduh

b. Merasa tidak nyaman

7. Saat anda berada di kawasan industri ini apakah anda dapat merasa nyaman?
a. Ya, lanjut ke no.5
b. Tidak, lanjut ke no.6

8. Apa yang dapat memberikan kenyamanan pada RTH?

a. Adanya tanaman (pohon, semak, rumput) yang cukup banyak

b. Adanya fasilitas bangunan maupun perkerasan lainnya yang memadai

c. Lainnya .......

9.Apakah yang dapat mengurangi kenyamanan pada RTH?

a. Terbatasnya tanaman (pohon, semak, rumput) di sekitar kawasan

b. Terbatasnya fasilitas RTH seperti tempat duduk, gazebo, kolam.

c. Lainnya.......

10. Apakah menurut anda ruang terbuka hijau $(\mathrm{RTH})$ atau area hijau itu di kawasan PT KS penting?

a. Ya, karena......

b. Tidak, karena ......

\section{Ruang Terbuka Hijau di Kawasan Industri PT KS}

11. Apakah kawasan industri PT KS sudah memiliki ruang terbuka hijau yang baik?

a. Ya, sudah cukup baik

b. Belum cukup baik

12. Apakah RTH di kawasan industri PT KS sudah fungsional?

a. Sudah berfungsi dengan baik

b. Belum berfungsi dengan baik

13.Bagaimana menurut anda jika kawasan industri disini hanya didominasi oleh bangunan ataupun perkerasan lainnya?

a. Akan lebih sejuk dan nyaman

b. Akan sangat panas dan tidak nyaman

14. Apakah anda merasa nyaman saat berada di Taman CRM?

a. Nyaman, karena...

b. Tidak nyaman, karena... 
15. Apakah anda merasa nyaman saat berada di Taman Masjid HSM?
a. Nyaman, karena...
b. Tidak nyaman, karena...

16. Apakah anda merasa nyaman saat berada di Lapangan?

a. Nyaman, karena...

b. Tidak nyaman, karena...

17. Apakah anda merasa nyaman saat berada di RTH Pabrik DRP?
a. Nyaman, karena...
b. Tidak nyaman, karena...

18. Apakah anda merasa nyaman saat berada di RTH Kantor HSE?
a. Nyaman, karena...
b. Tidak nyaman, karena...

19. Apakah jalur hijau jalan dapat memberikan kenyamanan?
a. Ya, karena...
b. Tidak, karena...

\section{Aktivitas di Ruang Terbuka Hijau}

20. Apakah anda sering melakukan aktifitas di Ruang Terbuka Hijau?
a. Ya, karena.
b. Tidak, karena.......

21. Apa aktivitas anda di luar ruangan ketika beristirahat?
a. Tetap di dalam ruangan
b. Makan dan minum di kantin
c. Duduk-duduk di bawah pohon d.Lain-lain, sebutkan:

22. Menurut anda, apakah fasilitas istirahat di luar ruangan (outdoor) bagi karyawan di PT KS sudah cukup?
a. Sudah
b. Belum

23. Menurut anda, apakah pohon peneduh di sekitar kawasan sudah cukup untuk memberikan kenyamanan istirahat anda di luar ruangan?
a. Ya
b. Tidak

24. Menurut anda, apakah keindahan dari penataan pohon-pohon di sekitar kawasan dapat mengurangi kejenuhan anda dalam bekerja?
a. Ya
b. Tidak

25. Kriteria lokasi beristirahat di luar ruangan yang paling sesuai untuk anda seperti apa?
a. Teduh
b. Tidak berisik
c. Sejuk
d. Luas
e. Indah

Tuliskan saran anda mengenai ruang terbuka hijau yang anda harapkan di kawasan industri PT KS 
Lampiran 2 Lembar Kuesioner Masyarakat

\section{KUESIONER PENELITIAN \\ EVALUASI KENYAMANAN TERMAL DAN KECUKUPAN RUANG TERBUKA HIJAU DI KAWASAN INDUSTRI PT KRAKATAU STEEL, KOTA CILEGON}

Kepada Responden yang terhormat,

Dalam rangka menyelesaikan tugas akhir di Departemen Arsitektur Lanskap, Fakultas Pertanian, Institut Pertanian Bogor, diperlukan dukungan saudara untuk mengisi kuesioner ini.

Kuesioner ini diedarkan untuk mengetahui persepsi dan preferensi karyawan terhadap penggunaan ruang terbuka hijau (RTH) di kawasan industri. Untuk itu, saya sangat mengharapkan kesediaan saudara meluangkan waktu untuk mengisi kuesioner ini. Masukan dan informasi yang jujur, benar dan akurat sangat diharapkan, agar informasi ilmiah yang akan disajikan benar-benar dapat dipertanggung jawabkan dihadapan semua pihak.

Terima kasih atas bantuan dan kesediaannya dalam mengisi kuesioner ini.

Lupita Rachma

\section{Identitas Responden}

Nama :

Usia :

Pendidikan Terakhir :

II. Pilihlah Salah Satu Jawaban Yang Paling Benar Menurut Pendapat Anda. Beri Tanda Silang (X) Pada Pilihan Anda dan Isilah Titik - Titik yang disediakan.

1. Sudah berapa lama anda tinggal di permukiman ini?
a. $<5$ tahun
b. $>10$ tahun
c. $>5$ tahun
d. Lainnya, ....

2. Apakah menurut anda kegiatan industri PT KS dapat menjaga kondisi lingkungan di sekitarnya?
a. Ya
b. Tidak

3. Apakah anda sering berada di dalam/ sekitar kawasan industri ini?
a. Sering
b. Jarang
c. Tidak pernah

4. Kegiatan/ aktivitas apa yang anda lakukan di dalam/ sekitar kawasan industri ini?
a. Bekerja di dalam kawasan industri
b. Hanya lewat kawasan industri
c. Lainnya ..... 
5. Apakah menurut anda kawasan industri banyak memberikan keuntungan?

a. Ya, karena .......

b. Tidak, karena......

6. Apakah menurut anda kawasan industri banyak memberikan kerugian?

a. Ya, karena .......

b. Tidak, karena......

7. Apa pemikiran atau bayangan anda ketika berada di kawasan industri?

a. Banyak bangunan dan lingkungan cenderung panas, kotor, dan kering.

b.Banyak pepohonan dan tanaman lainnya sehingga terasa sejuk dan nyaman.

c. Banyak bangunan tetapi ada beberapa tanaman di sekitarnya.

8. Saat anda berada di sekitar kawasan industri ini apakah anda dapat merasa nyaman?

a. Ya, karena...

b. Tidak, karena....

c. Tidak tahu

9. Apa yang dapat memberikan kenyamanan di sekitar kawasan industri?

a. Suhu udara tidak panas

b. Tidak banyak debu

c. Lainnya .......

\section{Ruang Terbuka Hijau}

Ruang Terbuka Hijau (RTH) adalah bagian dari ruang-ruang terbuka (open spaces) suatu wilayah yang diisi oleh tumbuhan, tanaman, dan vegetasi (endemik, introduksi) guna mendukung manfaat langsung dan/atau tidak langsung yang dihasilkan oleh RTH dalam wilayah tersebut yaitu keamanan, kenyamanan, kesejahteraan, dan keindahan.

10. Apakah anda sudah mengetahui istilah ruang terbuka hijau (RTH) sebelumnya?
a. Ya
b. Tidak

11. Bagaimana menurut anda kondisi lingkungan yang banyak terdapat tanamannya?
a. Sejuk, bersih, dan sehat
b. Panas, kotor, dan lembab
c. Biasa saja

12. Apakah yang anda rasakan ketika berada di tempat yang banyak terdapat pohon maupun tanaman lainnya?
a. Merasa lebih nyaman dan teduh
b. Merasa tidak nyaman
c. Biasa saja

13. Apakah menurut anda ruang terbuka hijau (RTH) atau area hijau itu penting?

a. Ya, karena......

b. Tidak, karena ......

14. Apakah di suatu kawasan industri perlu adanya ruang terbuka hijau?
a. Ya, karena ......
b. Tidak, karena ....... 


\section{Ruang Terbuka Hijau di Kawasan Industri PT Krakatau Steel}

15. Apakah kawasan industri PT Krakatau Steel sudah memiliki ruang terbuka hijau yang baik?
a. Ya, sudah cukup baik
b. Tidak sama sekali
c. Tidak tahu

16. Bagaimana menurut anda jika kawasan industri disini hanya didominasi oleh bangunan ataupun perkerasan lainnya?

a. Akan lebih sejuk dan nyaman

b. Akan sangat panas dan tidak nyaman

c. Biasa saja

17. Bagaimana menurut anda dampak yang dirasakan masyarakat jika banyak ruang terbuka hijau di kawasan industri ini?
a. Lebih sejuk dan nyaman
b. Akan sangat panas dan tidak nyaman
c. Biasa saja

18. Apakah menurut anda ruang terbuka hijau mampu memperbaiki kondisi lingkungan di kawasan industri ini?
a. Ya, karena
b. Tidak, karena .......

19. Bagaimana ruang terbuka hijau yang anda harapkan di Kawasan Industri PT Krakatau Steel?

-Terima kasih atas perhatian dan kerja samanya- 
Lampiran 3 Kuesioner untuk Analisis SWOT

KUESIONER PENELITIAN

EVALUASI KENYAMANAN TERMAL DAN KECUKUPAN RUANG TERBUKA HIJAU DI KAWASAN INDUSTRI PT KRAKATAU STEEL, KOTA CILEGON

\section{Identitas Responden}

Nama :

Jabatan :

\section{EAKTOR INTERNAL}

Fujuannya untuk mendapatkan faktor-faktor yang menjadi kekuatan dan kelemahan dari RTH di Kawasan Industri PT KS.

\begin{tabular}{|c|c|c|c|}
\hline Faktor & $\begin{array}{l}\text { Sangat } \\
\text { Penting }\end{array}$ & Penting & $\begin{array}{ll}\text { Cukup } & \text { Kurang } \\
\text { Penting } & \text { Penting }\end{array}$ \\
\hline
\end{tabular}

Kekuatan

- Terdapat pembagian tugas dalam pengelolaan RTH

- Terdapat upaya penghijauan lingkungan secara berkelanjutan

- Upaya perusahaan terhadap penambahan tanaman baru pada RTH

- Pihak perusahaan memiliki nursery untuk menyuplai kebutuhan tanaman

- Terdapat area taman di lingkungan industri

- Kesadaran karyawan tentang pentingnya RTH

Kelemahan

- Dominasi oleh bangunan pabrik yang cukup padat

- Kurangnya sarana dan prasarana untuk pemeliharaan RTH

- Belum ada tenaga ahli yang mengerti RTH

- Perusahaan belum memiliki standar operasional procedure pemeliharaan RTH

- Pihak pengelola RTH masih sulit mengajukan permohonan dana

- RTH belum megakomodasi fasilitas beristirahat bagi karyawan 


\begin{tabular}{ccccc}
\hline \multirow{2}{*}{ Faktor } & Sangat & Penting & Cukup & Kurang \\
& Penting & & Penting & Penting \\
\hline
\end{tabular}

\section{Peluang}

- Keberadaan kawasan industri sebagai penyedia lapangan pekerjaan

- Perhatian pemerintah kota terhadap RTH

- Pembatasan perluasan lahan industri

- Terdapat kelompok masyarakat yang peduli lingkungan

Ancaman

- Bencana alam

- Hama penyakit yang menyerang tanaman

- Iklim yang kurang mendukung pertumbuhan tanaman

- Kurangnya pengetahuan masyarakat terhadap RTH 


\section{RIWAYAT HIDUP}

Penulis bernama lengkap Lupita Rachma, dilahirkan di Serang, Provinsi Banten pada tanggal 30 Juni 1996. Penulis adalah anak kedua dari tiga bersaudara dari pasangan Bapak Marlan dan Ibu Tuti Astuti. Penulis memulai pendidikan formal di TK YPWKS IV pada tahun 2000-2002. Kemudian, pada tahun 2002 penulis meneruskan pendidikan di SD YPWKS V dan menyelesaikan pendidikan pada tahun 2008. Pada tahun yang sama penulis diterima di SMP Negeri I Cilegon dan menyelesaikan pendidikannya pada tahun 2011. Penulis melanjutkan pendidikan ke SMA Negeri 1 Cilegon dan menyelesaikan pada tahun 2014. Pada tahun yang sama, penulis diterima menjadi mahasiswa Institut Pertanian Bogor melalui Program SNMPTN di Departemen Arsitektur Lanskap, Fakultas Pertanian, Institut Pertanian Bogor.

Selama menjadi Mahasiswa, penulis aktif menjadi pengurus di beberapa Organisasi, yaitu Dewan Perwakilan Mahasiswa Fakultas Pertanian (2015-2016) dan Keluarga Mahasiswa Banten (2015-2016). Penulis juga pernah mengikuti kepanitiaan IPB Goes to School (2015), Masa Perkenalan Fakultas Pertanian (2016), Masa Perkenalan Departemen (2016), Fieldtrip Metropolis (2016), Agriphoria (2016), dan Pemira Fakultas Pertanian (2016). Selama kuliah penulis mengikuti Unit Kegiatan Mahasiswa (UKM) klub berkuda atau disebut Equestrian Club IPB.

Penulis aktif dalam kegiatan Arsitektur Lanskap dan juga kegiatan kampus lainnya, yaitu menjadi peserta dalam lomba menulis cerpen pada Tingkat Persiapan Bersama, dan mengikuti lomba aerobik pada acara Olimpiade Arsitektur Lanskap IPB. Adapun sayembara yang pernah diikuti antara lain Indonesia Landscape Design Competition: Sudirman Monumental Streetscape yang diselenggarakan oleh Himpunan Mahasiswa Arsitektur Lanskap (Himaskap) pada tahun 2017. Dalam kegiatan akademik, penulis pernah berkesempatan menjadi asisten praktikum untuk mata kuliah Perencanaan Lanskap pada tahun ajaran 2017-2018. Selama studi di IPB, penulis juga memperoleh beasiswa PPA. 